\title{
46. DIAGENESIS OF PLATFORM CARBONATES, WODEJEBATO GUYOT, MARSHALL ISLANDS ${ }^{1}$
}

\author{
Paul Enos, ${ }^{2}$ Gilbert F. Camoin, ${ }^{3}$ Paul A. Wilson, ${ }^{4}$ Bradley N. Opdyke, ${ }^{5}$ Jonathan M. Lincoln, ${ }^{6}$ Jennifer L. Wyatt, ${ }^{7}$ \\ Terrence M. Quinn, ${ }^{7}$ Philippe Ebren, ${ }^{3}$ Michel Colonna, ${ }^{3}$ and Gareth R. Davies ${ }^{8}$
}

\begin{abstract}
Cores from five sites on Wodejebato Guyot show that diagenesis played a major role in forming the platform limestones. Five morphologically distinct cement types representing several diagenetic environments, extensive dissolution porosity, and widespread neomorphism of metastable components to calcite with mimic or coarsely crystalline textures are observed.

Radiaxial cement (RC) and a fibrous variant (RC-FIC) occur almost exclusively in primary pores in the upper $70 \mathrm{~m}$ of the inner perimeter ridge at the platform edge. These cements precipitated from shallow, warm marine waters. Prismatic limpid cement with uniform extinction (PLUC) occurs throughout the platform limestones in both primary and secondary porosity. Geologic, petrographic, and isotopic data indicate formation in deeper, cool marine waters, after drowning of the platform. Columnar, bladed, magnesian-calcite $\left(7 \mathrm{~mole} \% \mathrm{MgCO}_{3}\right.$ ) cement with sweeping extinction $(\mathrm{CC})$ is confined to a single core of a reef interval on the inner perimeter ridge. It occupies primary porosity as the first cement or overlies RC. This is an early, shallow-marine cement. Many caprinid rudist shells in this interval maintain their primary aragonite composition. Syntaxial overgrowth cement (SOC) is widely distributed, in small quantities, mainly in grainstones. It appears to have precipitated concurrently with or somewhat later than PLUC, presumably in the same deeper, cool, marine water.

Dissolution formed extensive molds, some vugs, and some small caverns, particularly in grainstones. Dissolution was most intense in the outer perimeter ridge at the platform edge. Molds also occur in muddier rocks and in reworked cobbles of wackestone. Geologic and petrographic evidence suggests that dissolution occurred both in meteoric waters during early subaerial exposure of Wodejebato Atoll and in cold marine waters after drowning, perhaps continuing to the present.

Neomorphism is most apparent in skeletons that were originally aragonitic, rudists and other mollusks in particular. Where the neomorphic calcite closely mimics the original wall structure, the original isotopic composition is only slightly altered. Coarsely crystalline neomorphic calcite has lower $\delta^{18} \mathrm{O}$ and $\delta^{13} \mathrm{C}$ values than the original shells, indicating meteoric alteration. Burial diagenesis is not an alternative on this guyot. Matrix and magnesian calcite shells, such as benthic foraminifers and red algae, rarely show petrographic evidence of neomorphism, but some samples show dramatic isotopic shifts to lower ${ }^{18} \mathrm{O}$ and ${ }^{13} \mathrm{C}$, suggesting meteoric alteration.

Isotopic shifts to lower values suggest two incursions of meteoric water at the lagoon site and on the inner perimeter ridge. Traces of root structures indicate a third exposure episode within the lagoon. The clearest signal of meteoric water is in a shift to lower isotopic values, primarily in ${ }^{18} \mathrm{O}$, at the top of platform carbonates. Isotopic data are available only from the lagoon and inner perimeter ridge sites, but a probable microkarst surface truncates platform limestones on the outer perimeter ridge, indicating that the entire atoll was exposed prior to drowning.
\end{abstract}

\section{INTRODUCTION}

Diagenesis of platform carbonates, such as those drilled in Wodejebato Guyot, Marshall Islands, commonly plays a major or even dominant role in determining the character of the limestones resulting from the initial sediments. Diagenesis can be extremely important in understanding the postdepositional history of the rocks because diagenetic products record information about the environment in which the diagenetic changes occurred, notably the general chemistry of the water and the temperature of alteration. Of particular importance in establishing the geologic history is the fact that episodes of subaerial exposure, which necessarily mean lowering of relative sea level in subtidal car-

\footnotetext{
'Haggerty, J.A., Premoli Silva, I., Rack, F., and McNutt, M.K. (Eds.), 1995. Proc ODP, Sci. Results, 144: College Station, TX (Ocean Drilling Program).

${ }^{2}$ Department of Geology, University of Kansas, 120 Lindley Hall, Lawrence, KS 66045, U.S.A.

${ }^{3}$ Centre de Sédimentologie et Paléontologie, U.R.A. 1208 du C.N.R.S., Université de Provence, F-13331 Marseille Cedex 3, France.

${ }^{4}$ Department of Earth Sciences, University of Cambridge, Downing Street, Cambridge CB2 3EQ, United Kingdom.

${ }^{5}$ Department of Earth Sciences, University of Michigan, Ann Arbor, MI 48109, U.S.A. (Present address: Department of Geology, Faculty of Science, The Australian National University, Canberra ACT 0200, Australia.)

${ }^{6}$ Department of Earth and Environmental Studies, Montclair State University, Upper Montclair, NJ 07043, U.S.A.

${ }^{7}$ Department of Geology, University of South Florida, Tampa, FL 33620-5200, U.S.A.

${ }^{8}$ Faculty of Earth Science, Vrije Universiteit, Amsterdam, The Netherlands.
}

bonates, can commonly be recognized from the diagenetic materials, particularly in the fabric and chemistry of carbonate cements.

Diagenesis is commonly a two-way street: diagenesis giveth and diagenesis taketh away. In addition to cementing carbonate sediments into rock, diagenesis commonly alters the original mineralogy, morphology, and chemistry of the particles, and removes material to produce secondary porosity. In many samples from Wodejebato Guyot, up to half of the original grains have been removed by dissolution to produce molds or vuggy porosity. The alteration and dissolution are much more difficult to interpret in terms of geologic history than are cements. The alternation of grains, neomorphism, produces new material that can commonly be interpreted in terms of temperature and water chemistry, but is difficult to place in time because the original material is typically altered without crosscutting relationships between successive events. The timing of secondary porosity is more readily interpreted by crosscutting relationships with cements and original grains, but the result is removal of material so no record of temperature or water chemistry is preserved. Generally the fabrics of dissolution cannot be related to specific environments with any assurance; in contrast some cement morphologies give clear signals as to the diagenetic environment.

All of the specialty reports on the platform carbonates from the five drilling sites on Wodejebato gave some attention to diagenesis (Wyatt et al., Opdyke et al., Camoin et al., Lincoln et al., and Enos et al., all in this volume). Deposition and diagenesis of the volcanic rocks and argillaceous sediments that underlie the platform carbonates (Holmes, this volume) and of the pelagic carbonates that overlie the platform 
carbonates (Watkins et al., this volume) provide the prologue and epilogue of the diagenetic history of the platform carbonates.

\section{DIAGENESIS BEFORE CARBONATE-PLATFORM DEPOSITION}

The recorded diagenetic history of Wodejebato Atoll, as it then was, began some time after cessation of volcanism. The youngest reliable date on basement extrusive rocks is $78.4 \pm 2.8 \mathrm{Ma}$, mid-Campanian (Pringle and Duncan, this volume). However, all basalts are reversed polarity, suggesting that none is younger than the end of Chron 33R or $79 \mathrm{Ma}$ (Gee and Nakanishi, this volume). Weighted mean for Wodejebato basalts is $83.2 \pm 1.1 \mathrm{Ma}$ (Pringle and Duncan, this volume), at the very onset of Chron 33R. Carbonate sedimentation began in the late Campanian (Chron CC22), $76 \mathrm{Ma}$ (Erba et al., this volume). Thus, the weathering of the basaltic basement (Premoli Silva, Haggerty, Rack, et al., 1993; Holmes, this volume) must have occurred in this interval of 2.4-3 m.y. Events other than weathering must also be fitted into this time slot. Seismic profiles show that Wodejebato volcano, as it then was, was nearly flat-topped before the platform carbonates squared off the shoulders slightly (Bergersen and Camoin et al., both in this volume). This considerable erosion, perhaps by wave planation, occurred before the weathering profiles were developed.

A weathering horizon approximately $23 \mathrm{~m}$ thick was encountered at Site 873 near the center of Wodejebato Guyot. The upper portion is a massive red clay typical of oxygenated tropical soils (Holmes, this volume). An underlying thin, drab-mottled zone suggests that weathering occurred in a lowland or some poorly drained area, rather than in an upland. A gradation from mottled clays downward into clays overprinted on basalt textures and into fresh basalts is taken to indicate lack of transport in the soils (Holmes, this volume), which necessarily postdate erosional leveling of the volcanic edifice.

Clay profiles cored at Sites 874 and 877 on the inner perimeter ridge of Wodejebato were interpreted as the base ( $\mathrm{C}$ horizon) of a former soil because relict structure of the parent basalt is still discernible (Holmes, this volume). Erosion of the upper zones of the soil was followed by deposition of organic-rich mud. The reducing conditions that produced the dark, organic-rich clays extended down into the highly oxidized soil profile and formed natrojarosite or natroalunite (Holmes, this volume). Peat also developed above the organic-rich muds at Hole $877 \mathrm{~A}$, and the base of the platform carbonates has pyrite-rich intervals (Premoli Silva, Haggerty, Rack, et al., 1993). These prolonged and intensive reducing conditions are explained by a rising water table as the volcanic pedestal subsided isostatically (Holmes, this volume).

No such clays were recovered at Sites 875 and 876 on the outer perimeter ridge of Wodejebato, where carbonate grainstones rest directly on basalt (Premoli Silva, Haggerty, Rack, et al., 1993; Enos et al., this volume). No hint of an eroded weathering profile, such as terrigenous clasts or increased clay content, was observed in the limestones. The uppermost basalt at Site 876 is brownish in color, suggesting a brief moment in the sun (Premoli Silva, Haggerty, Rack, et al., 1993 , p. 279; M.A. Holmes, pers. comm., 1994). An alternative possibility is hydrothermal alteration from within the volcanic pile. Verypale-brown (10YR $8 / 3$ and 7/3) and brownish yellow (10YR 6/6) colors near the base of the limestones in Holes $875 \mathrm{C}$ and $876 \mathrm{~A}$ suggest oxidized iron derived from the basaltic basement (Enos et al., this volume). The overlying limestones are uniformly white. The highly vesicular basalt that underlies the limestone at Site 875 shows significant non-oxygenated alteration, in contrast to Site 876 , and the addition of $1 \%-2 \%$ secondary pyrite along fractures near the contact. Limestones just above the contact also contain several percent of pyrite that postdates both carbonate dissolution and cementation (Enos et al., this volume).

Deposition of platform carbonates above the weathering profiles at Sites 873,874 , and 877 records a relative rise in sea level (Premoli Silva, Haggerty, Rack, et al., 1993; Camoin et al., this volume) of at least $51.2 \mathrm{~m}$, the difference in depth of the base of the platform carbonates at Site $873(1486.5 \mathrm{mbsl})$ and at Sites 874 (1537.72 mbsl) and 877 (1537.7 mbsl).

The contact of submarine limestone on top of basalt at Sites 875 and 876 on the outer perimeter ridge does not, however, require a relative rise of sea level unless the basalt was subaerially exposed. The volcanic pile clearly built above sea level and supported land vegetation for some time before the onset of carbonate deposition. Palynomorphs and wood fragments from the clays and a peat layer $20 \mathrm{~cm}$ thick recovered at Site 877 document this (Premoli Silva, Haggerty, Rack, et al., 1993; Holmes, this volume). In the absence of a recognizable weathering profile at Sites 875 and 876 , it is entirely possible that limestone deposition began at these sites as soon as the volcanics built into the photic zone. This could happen quite independently of eustatic sea level. However, the oldest limestones at Sites 875 and 876 are about 4 m.y. younger than those that overlie the weathering profiles at Sites 873, 874, and 877 (Erba et al. and Enos et al., both in this volume). The depth of the base of platform carbonates at outer perimeter ridge sites is essentially the same as at inner ridge sites (1534.8 mbsl at Site $875 ; 1544.3 \mathrm{mbsl}$ at Site 876 ). This makes the apparent delay in onset of carbonate deposition on the hard volcanic substrate of the outer ridge, an ideal place for biotic attachment, quite enigmatic.

If the outer perimeter was subaerially exposed, however, as hinted by the basalt discoloration at Site 876 , we can only say that relative sea level dropped somewhere below the top of the volcanics at Site 876 (i.e., below the present sea level of $1544.3 \mathrm{~m}$ ). Ironically, the top of basaltic basement at Site 876 is $9.5 \mathrm{~m}$ below that at Site 875 (Enos et al., this volume), which gives no hint of subaerial exposure. The sites are $1.67 \mathrm{~km}$ apart, so some differential tilting is possible, but they are located on the same circumferential ridge. The possibility of subaerial exposure at Site 876 warrants further study because of its possible significance in fixing the absolute position of sea level during the Campanian.

\section{DIAGENESIS OF PLATFORM CARBONATES}

Synthesis of the lithogenesis of the platform limestones will begin with a review of the significant diagenetic features at each site, in part reported elsewhere in this volume, and in part from unpublished petrographic observations. This is the work of several different groups: Lincoln, Enos, and Ogg, Site 873; Wyatt, Quinn, and Davies, Site 874; Camoin et al., Sites 874 and 877; Enos, Camoin, and Ebren, Sites 875 and 876; Opdyke, Wilson, and Enos, Site 877; and J.M. Lincoln (unpubl. data), Site 874. The main diagenetic features observed include cementation, dissolution, and neomorphism.

Cementation includes a variety of cement morphologies (Figs. 1-4) that represent, presumably, a variety of diagenetic environments. The definitive parameters in cementation are fluid chemistry and temperature in the diagenetic milieu. Pressure was of minor importance in Wodejebato, where the stratigraphy indicates a maximum depth of burial less than $200 \mathrm{~m}$. Pore water within the extremely porous and permeable platform carbonates was almost certainly at hydrostatic pressure throughout the evolution of the guyot.

The end members of fluid chemistry to which Wodejebato carbonates were exposed probably ranged from seawater with slightly elevated salinities $(\sim 40 \%$ from ongoing study of fluid inclusions in marine cements) to fresh meteoric water. There are some hints in samples recovered of vadose conditions, in which air and soil gases are important pore fluids. No indication was found that hypersaline waters were ever present in Wodejebato. The temperature end members also spanned a limited range. The carbonates are today bathed in cold seawater, beneath the oceanic thermocline; ambient temperatures are about $10^{\circ} \mathrm{C}$ (Premoli Silva, Haggerty, Rack, et al., 1993). At the time of deposition near sea level in equatorial waters, ambient temperatures were probably about $30^{\circ} \mathrm{C}$ in shallow parts of the lagoon. The rocks have probably never been deeper then at present, nor 
A

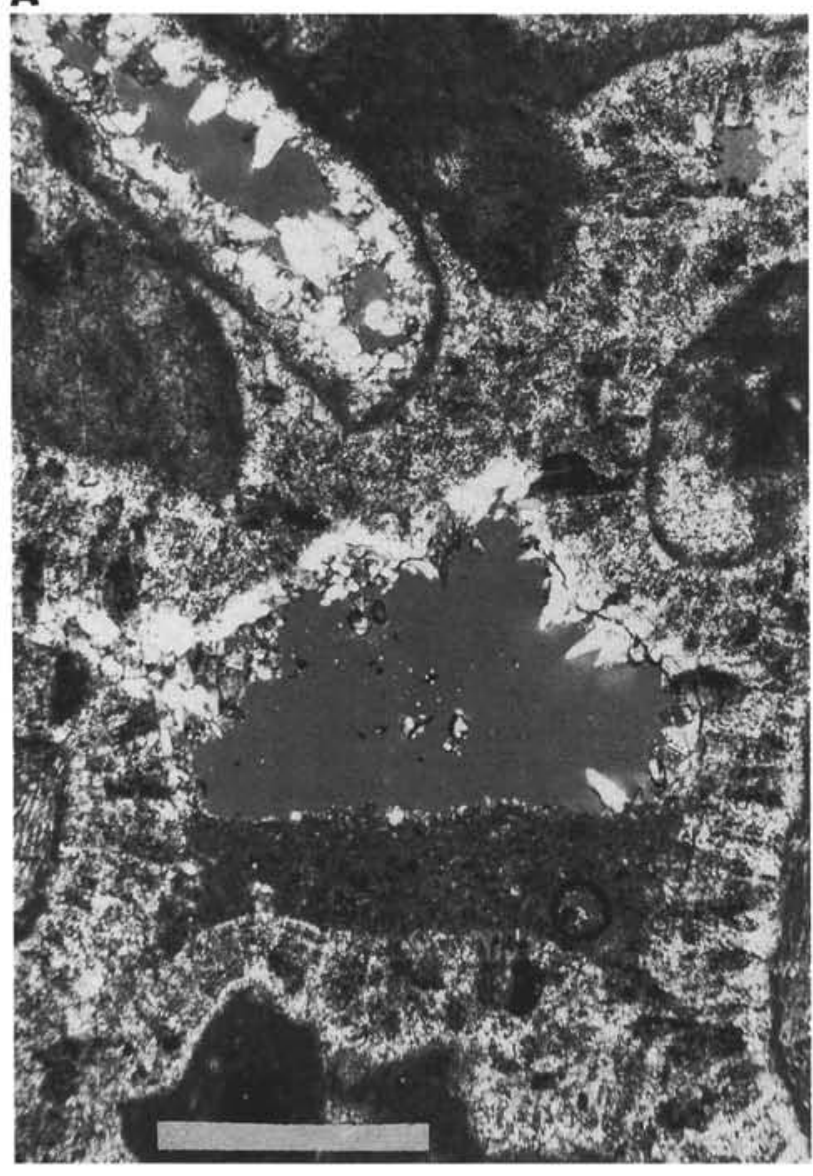

$\mathbf{B}$

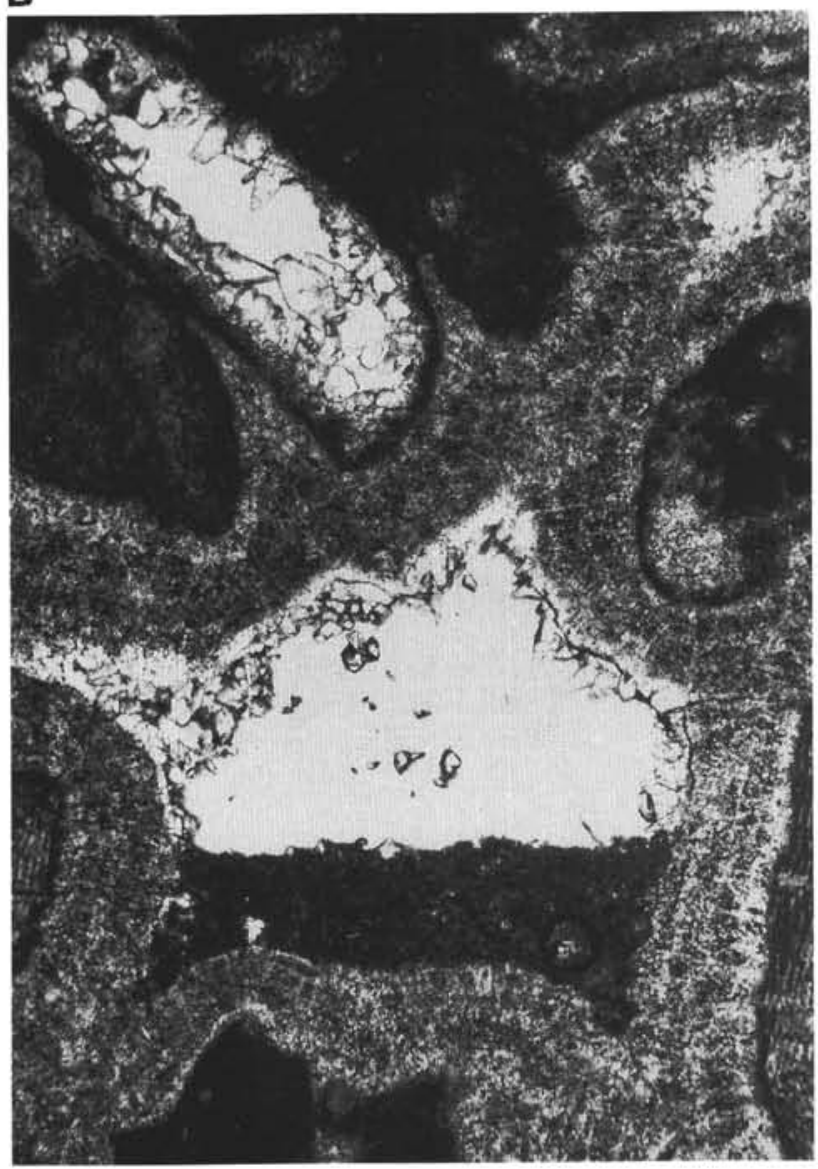

$0.5 \mathrm{~mm}$

Figure 1. Radiaxial cement as isopachous crust in interparticle pores. A. Crossed polars. B. Plane light. Scale bar is $0.5 \mathrm{~mm}$. Sequence is RC $\rightarrow$ internal sediment? $\leftrightarrow$ ? dissolution $\rightarrow$ PLUC. PLUC is the only cement in the micrite-rimmed mold at the top left. Sample $144-877 \mathrm{~A}-1 \mathrm{R}-1,137 \mathrm{~cm}$.

much elevated above their original depositional level. Hydrothermal fluids may possibly have emanated from the volcanic edifice, but no evidence such as minerals indicative of hydrothermal alteration was noted within the clays that overlie the volcanic rocks at three sites (873, 874, and 877).

Dissolution produced extensive secondary porosity in the form of molds and vugs (terminology of Choquette and Pray, 1970; Premoli Silva, Haggerty, Rack, et al., 1993, pp. 17-19). A variety of diagenetic environments is possibly represented by the extensive secondary porosity in many intervals, particularly in the outer perimeter ridge, Sites 875 and 876 (Premoli Silva, Haggerty, Rack, et al., 1993; Enos et al., this volume). However, it is much more difficult to quantify dissolution diagenesis because the evidence is removed; the net product is a void.

Neomorphism is most obvious in the conversion of original metastable calcium-carbonate polymorphs, aragonite and magnesian calcite, to the stable minerals of carbonate rocks, calcite in the case of Wodejebato. Contrary to expectations, dolomite is virtually absent. Neomorphic products range from the obvious, where the original crystals of a fossil or a pellet were converted to a much different crystal habit, to the obscure, where the original structure is faithfully preserved, but the mineralogy is completely stabilized as calcite. At the "obvious" end member, the difficult call is whether the crystals present represent fine-scale, incremental alteration to a stable mineralogy, or whether stabilization took the two-step route of dissolution to form a mold, that was later the site of calcite crystal growth. These processes were called "neomorphism by inversion" and "solution- cavity fill," respectively, by Folk (1965). Bathurst (1975) presents a lucid discussion of clues for differentiating neomorphic calcite from passively precipitated cement. An unequivocal differentiation is not always possible at present.

Before considering the individual sites, it is necessary to establish a uniform terminology for describing diagenetic calcite-cements and neomorphic spar. Onboard the largely descriptive terminology of Folk (1965) was used (Premoli Silva, Haggerty, Rack, et al., 1993, pp. 17-19). For more detailed petrology in shore-based studies, more precise descriptions were necessary. The nomenclature and abbreviations for cements outlined by Opdyke et al. (this volume; modified here as Table 1) are used.

\section{SITE 873-CENTER OF WODEJEBATO GUYOT: "IN THE LAGOON"}

Site 873 was located near the center of the Wodejebato Guyot to sample lagoonal facies. Some moderately restricted, muddy facies (wackestones and packstones) were encountered in the middle portion of the 100-m section of platform carbonates, in Subunit IIIA-2 and the upper part of Subunit IIIB (Lincoln et al., this volume). Packstones and some grainstones were interbedded throughout and were dominant in recovery from the upper $25 \mathrm{~m}$ and the basal $25 \mathrm{~m}$. This platform-interior sequence was interpreted as "lagoonal" but dominated by storm deposition (Lincoln et al., this volume). Site 873 is the only Wodejebato site with a pelagic cap; $54 \mathrm{~m}$ of Neogene (mostly middle Miocene and late Pliocene) pelagic ooze overlie the 
Table 1. Summary of cement types (after Opdyke, Wilson, and Enos, this volume).

\begin{tabular}{|c|c|c|}
\hline Type & Essential characteristics & Other attributes \\
\hline $\mathrm{RC}$ & $\begin{array}{l}\text { Radiaxial cement. Inclusion-rich. Sweeping extinction. } \\
\text { Convergent optic axes in subcrystals. }\end{array}$ & $\begin{array}{l}\text { Aggregate crystals generally elongate, but some are equant. Distributed as isopachous crusts. } \\
\text { Crystal boundaries vague to irregular with multiple subcrystals. May grade into overlying } \\
\text { cement, obscuring terminations. Acute terminations common; multiple terminations rare. } \\
\text { Occurs in primary pores with a few exceptions. Locally reduces molds or vugs typically beneath } \\
\text { a bored, corroded hardground or exposure surface. Invariably an early cement; first generation or } \\
\text { overlying radiaxial fibrous cements. Virtually confined to upper } 75 \mathrm{~m} \text { of inner perimeter ridge } \\
\text { sites. Fascicular optic cement included as a variant. }\end{array}$ \\
\hline RC-FIC & $\begin{array}{l}\text { Radiaxial fibrous cement. Fibrous subcrystals with bladed or } \\
\text { equant aggregate habit. Inclusion rich. Sweeping extinction. } \\
\text { Convergent optic axes. Fibrous variant of RC. }\end{array}$ & $\begin{array}{l}\text { Crystal boundaries vague to irregular. Distributed as isopachous crusts that are commonly banded. } \\
\text { Typically grades into overlying cement (RC, CC, or PLUC). Multiple acute terminations rarely } \\
\text { visible. Occurs almost exclusively in primary pores. Invariably an early cement. }\end{array}$ \\
\hline $\mathrm{CC}$ & $\begin{array}{l}\text { Columnar, typically bladed. Clear. Sweeping extinction with } \\
\text { convergent optic axes. }\end{array}$ & $\begin{array}{l}\text { Observed only in Section 144-877A-5R-3, but forms up to } 16 \% \text { of bulk volume. Magnesian calcite, } \\
7 \text { mol\%. Generally pore-filling with sutured, polygonal boundaries on crusts. Mostly lines } \\
\text { primary pores (intergranular and intragranular), but occurs in a few molds. Irregular or curving } \\
\text { crystal boundaries. Acute or gradational terminations. }\end{array}$ \\
\hline PLUC & $\begin{array}{l}\text { Pyramidal, generally bladed. Limpid, but locally with inclusions } \\
\text { in early growth stages. Uniform extinction. }\end{array}$ & $\begin{array}{l}\text { Pore-lining crusts, but variable thickness. Extreme size range, Folk classes } 2 \text { through } 6 \text {. Linear } \\
\text { crystal boundaries. Acute terminations typical, but obtuse to rounded terminations common in } \\
\text { small crystals. Uniform extinction (locally slightly sweeping in early stages where syntaxial on } \\
\text { RC). Occurs in all pore types, primary and secondary, and in virtually all samples. Last or only } \\
\text { phase of cement, except where coprecipitated with or enveloped by syntaxial cement (SOC). }\end{array}$ \\
\hline SOC & Syntaxial overgrowth cement. & $\begin{array}{l}\text { Typically clear. Patchy distribution reflects substrate control by echinoderms, some bivalves and } \\
\text { large benthic foraminifers. Linear crystal boundaries. Obtuse or multiple terminations. Uniform } \\
\text { extinction. In primary pore space (BP, WP) with few exceptions. Late; abuts or envelopes } \\
\text { PLUC. Widely distributed, mostly in minor quantities and in grainstones. In inner perimeter } \\
\text { ridge sites, virtually confined to lower, grainstone subunits. }\end{array}$ \\
\hline
\end{tabular}
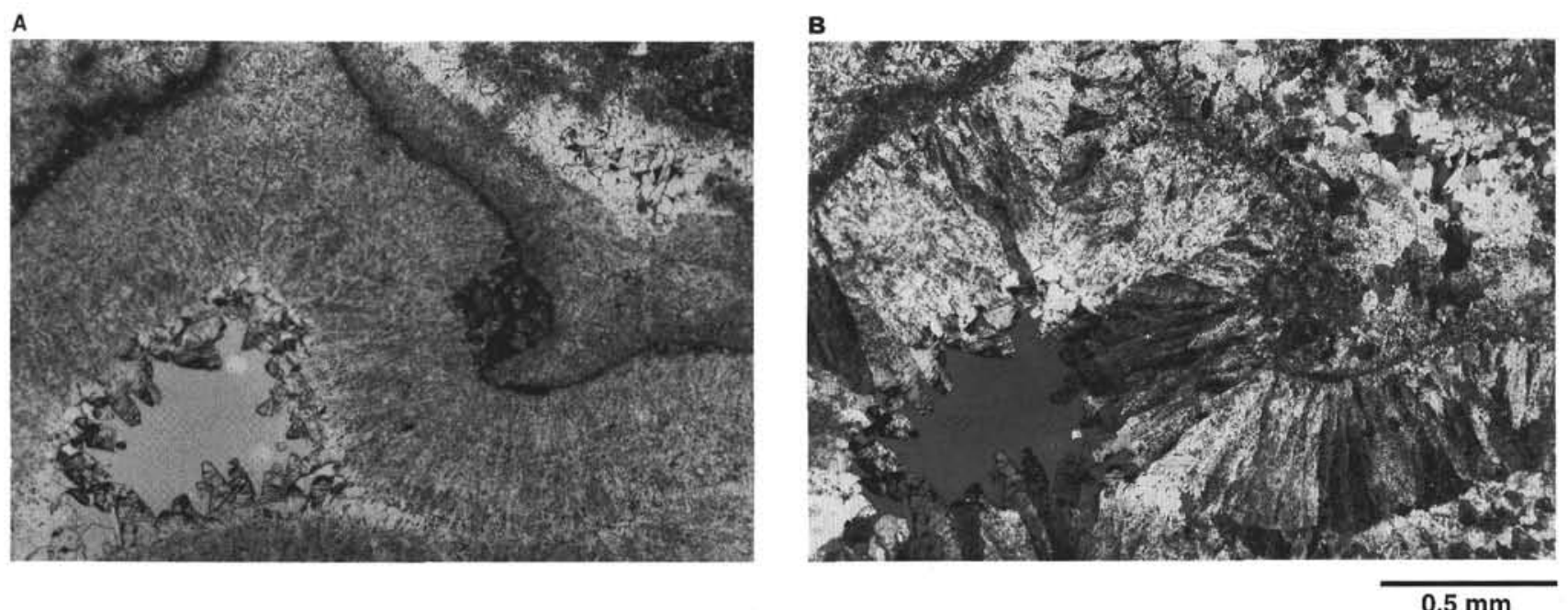

Figure 2. Radiaxial fibrous cement; fibrous variant of RC, in a shelter pore. A. Plane light. B. Crossed polars. Isopachous crust of RC-FIC is overlain by PLUC. Scale bar is $0.5 \mathrm{~mm}$. Sample 144-877A-1R-1, 4-8 cm.

ubiquitous Paleogene veneer of manganese-encrusted, phosphatic limestone (Premoli Silva et al. and Watkins et al., both in this volume).

The average amount of cement in platform-carbonate samples from Site 873 increases steadily from top to bottom (Fig. 5), although the minimum values remain near zero throughout. Some values that appear anomalously high result from cement precipitated in secondary, dissolution porosity, as well as in primary, intergranular pores.

Morphologically the cements vary little, except in size. Most of the cement crystals are pore-lining, bladed, or equant pyramids of limpid calcite with uniform extinction (PLUC in the terminology of Opdyke et al., this volume; Table 1 and Fig. 4). Sizes range from very finely crystalline $(<16 \mu \mathrm{m})$ to very coarsely crystalline $(1-4$ $\mathrm{mm}$ ). The very finely crystalline cements commonly have blunt or rounded terminations.

A few samples contain small volumes of equant cement as syntaxial overgrowths (SOC) on echinoderm or mollusk grains. Limpid crystals with uniform extinction are also present. They have a nar- rower size range (finely to coarsely crystalline) than the pore-lining PLUC crystals, but are typically somewhat coarser than the PLUC crystals in the same sample. In most cases, SOC crystals appear to overlie or overgrow PLUC cements. In a few cases, the relative age relationship is reversed or ambiguous; that is, PLUC crystals appear to overlie as well as underlie SOC. This suggests that PLUC and SOC may have grown at the same time, under the same diagenetic conditions. The difference in morphology would result from the substrate; it is well known that echinoderm fragments typically nucleate syntaxial overgrowths (cf. Bathurst, 1975). Overgrowths are less common on molluscan grains.

The only other type of cement recognized was a single example (Sample 144-873A-5R-1, 37-40 cm [88.7 mbsf]) of fine, fibrous crystals with sweeping extinction that form thin, multiple crusts lining both primary and secondary pores (Figs. 6-7). The crusts, as many as 12 in some large pores, underlie and are interbedded with very fine-grained internal sediment. 
A

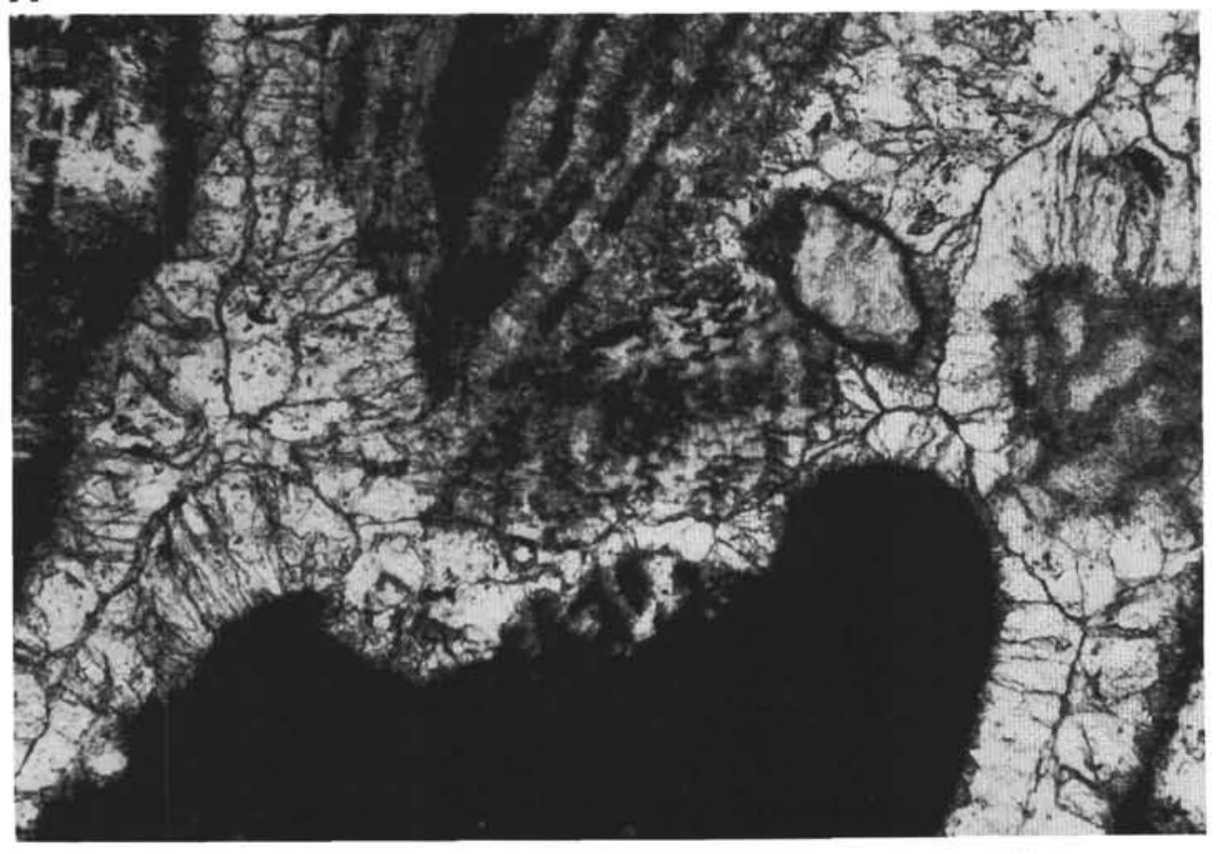

$200 \mu \mathrm{m}$

\section{B}

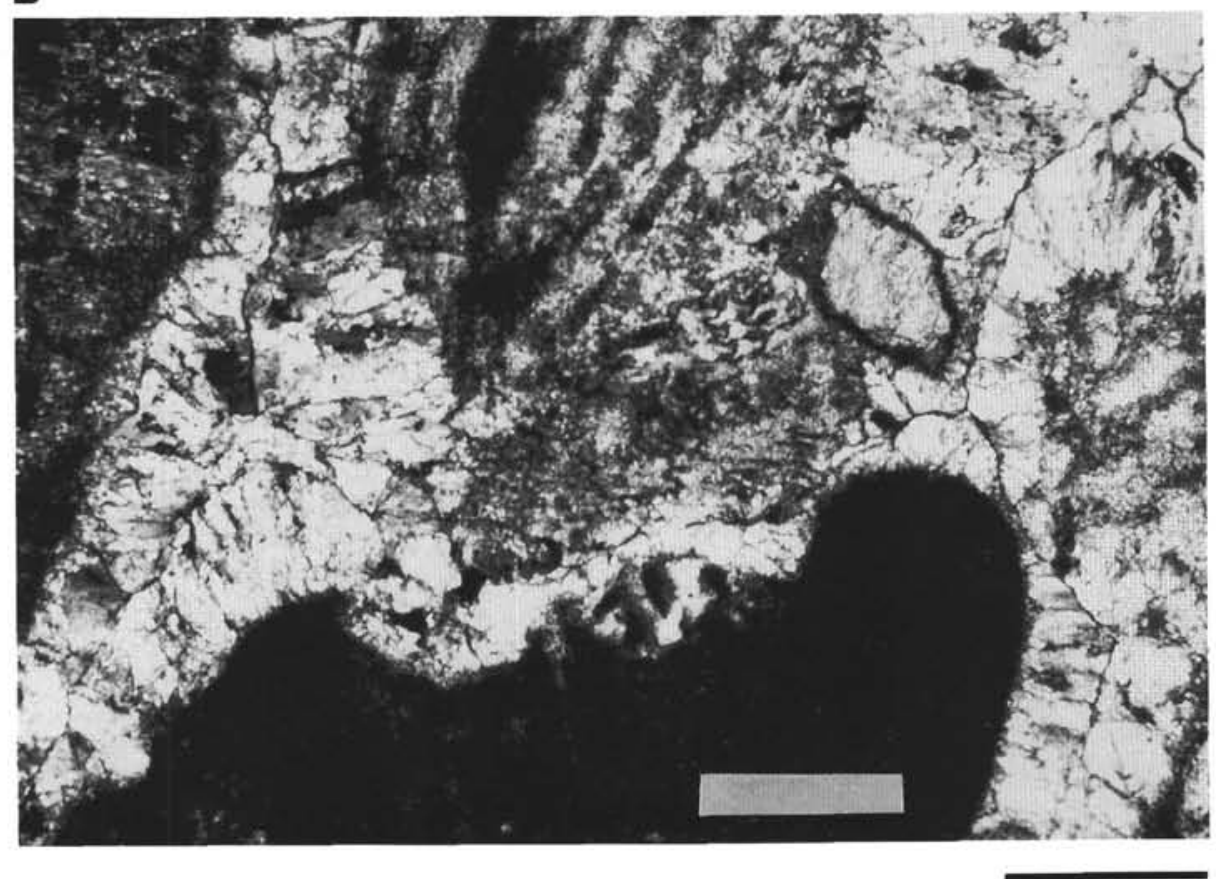

Figure 3. CC cement in interparticle pores. A. Plane light. B. Crossed polars. Scale bar is $0.2 \mathrm{~mm}$. Sample $144-877 \mathrm{~A}-5 \mathrm{R}-3,41 \mathrm{~cm}$.

Stable isotope compositions of cements from Site 873 show a considerable range $\left(-2.4 \%\right.$ to $+3 \% 0 \delta^{13} \mathrm{C} ;-7.8 \%$ to $\left.+2.9 \% 0 \delta^{18} \mathrm{O}\right)$, but most values fall between $1.5 \%$ and $3 \% 0 \delta^{13} \mathrm{C}$ and between $-1 \%$ and $+1 \% 0 \delta^{18} \mathrm{O}$ (Fig. 8). The samples lowest in ${ }^{18} \mathrm{O}(<-4)$ occur between 54.3 and $67.7 \mathrm{mbsf}$ and at 129 and $147 \mathrm{mbsf}$ (Fig. 8). Only the samples between 58 and $67.7 \mathrm{mbsf}$ are correspondingly low in ${ }^{13} \mathrm{C}(<0)$.
Average macroporosity at Site 873 decreases somewhat from top to base in the platform carbonates (Fig. 5). Pore types, in approximate order of abundance, are moldic (MO), intergranular (BP), vuggy (VUG), and intragranular (WP). Secondary porosity (MO and VUG) occurs throughout. Primary porosity (BP) persists in grain-supported fabrics near the top. Internal sediment with Paleogene planktonic 


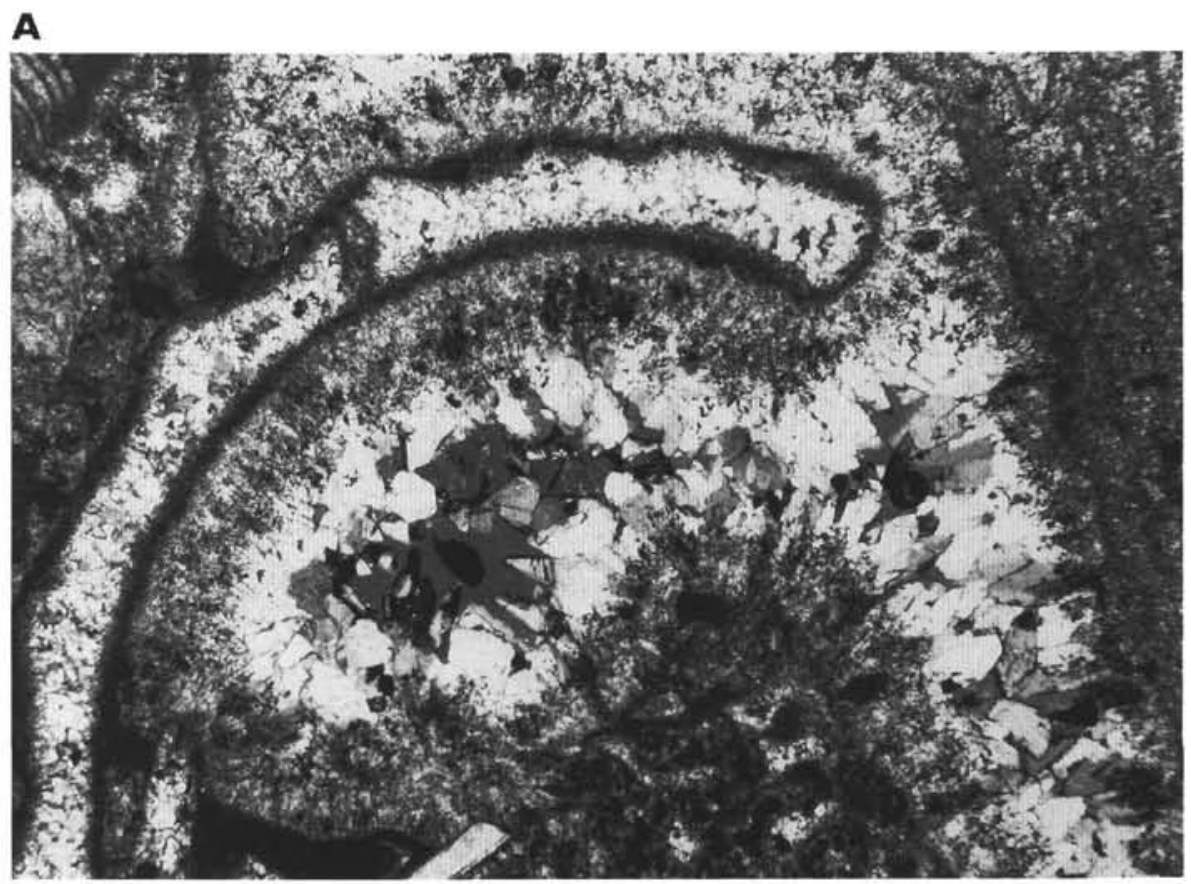

B

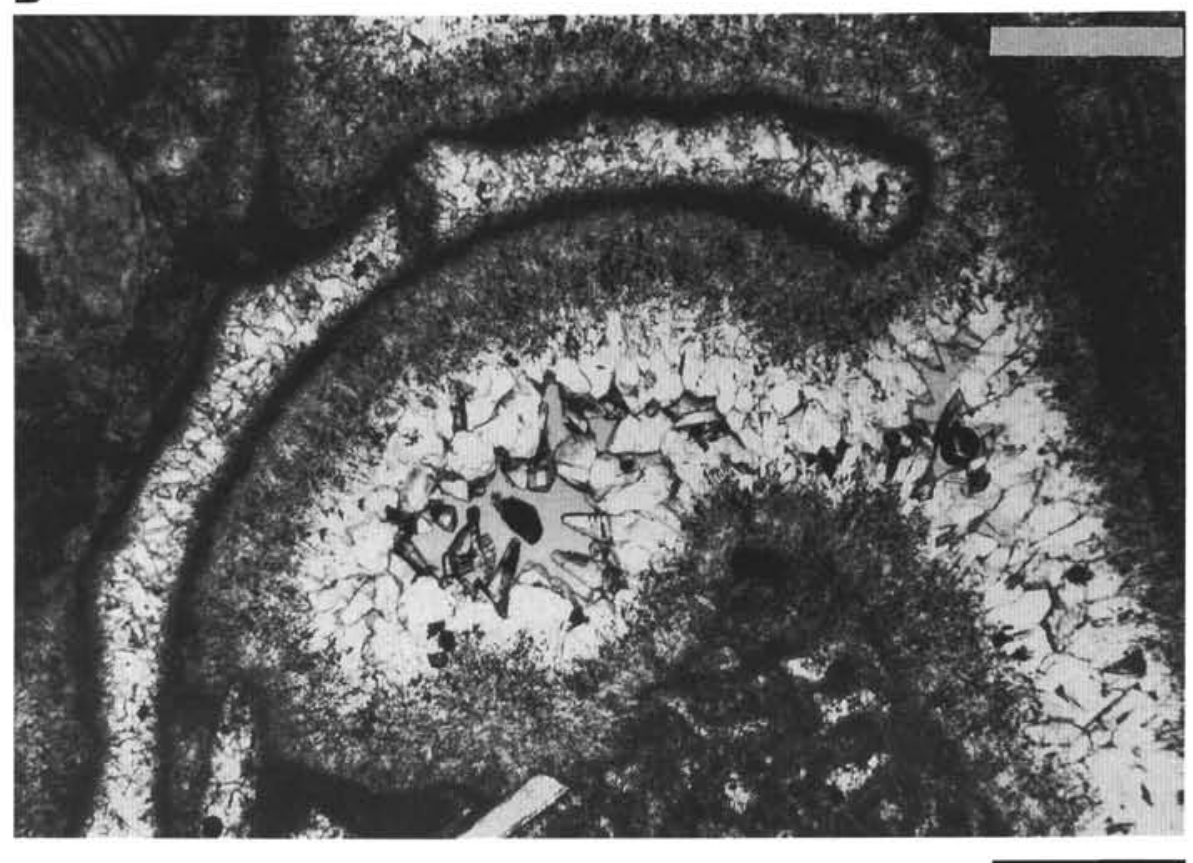

$0.5 \mathrm{~mm}$

Figure 4. PLUC overlying RC-FIC in interparticle and shelter pore. PLUC also fills micrite-rimmed mollusk mold (top left). A. Crossed polars. B. Plane light. Scale bar is $0.5 \mathrm{~mm}$. Sample $144-877 \mathrm{~A}-4 \mathrm{R}-1,94 \mathrm{~cm}$.

biota has filtered into both primary and secondary porosity near the top of the platform carbonates (Sample 144-873B-8N-1, 11-14 cm [58.11 mbsf]).

Neomorphic fabrics are not conspicuous except in the few samples of crystalline limestone with anomalous abundance of "cement." However, the metastable mineralogies (aragonite and magnesian cal- cite) that dominate in the sediment of carbonate platforms appear to have been completely replaced by calcite (no X-ray analyses were reported). Both fossils and matrix show a considerable range of stable isotope values with distinctly covariant trends (Fig. 8C). The highest values, here about $+2.5 \% \circ \delta^{13} \mathrm{C}$ and $-0.5 \% \circ \delta^{18} \mathrm{O}$ probably reflect primary composition (Given and Lohmann, 1985; Lohmann and Walker, 
1989). In these samples, the conservatives are mostly benthic foraminifers and red algae. The original mineralogy would have been magnesian calcite, which more commonly conserves isotopic composition through mineralogic stabilization to calcite than does aragonite. Surprisingly, the sole dasyclad alga, sampled at $127 \mathrm{mbsf}$, gives no hint of isotopic depletion from the original aragonite (Fig. 8A).

Shipboard core descriptions noted variously oriented tubes that in some cases branch and apparently taper downward (intervals 144873A-5R-1, 23-78 cm; -7R-1, 28-35 cm; -7R-1, 131-150 cm; and $-7 \mathrm{R}-2,3-6 \mathrm{~cm})$. These were tentatively interpreted as root structures. Thin-section examination did not substantiate this interpretation for Core 144-873A-7R. In Core 144-873A-5R, however, four samples from the interval 144-873A-5R-1,37-103 cm (88.6-89.3 mbsf) contain a variety of structures suggestive of roots. These include ovoid pores, reduced by cement and unfossiliferous internal sediment, which are much larger than the surrounding grains, but do not truncate them. Some of these pores are lined with micrite, locally interlayered with finely crystalline, isopachous cement, and occluded by coarser spar. Others are reduced by geopetal accumulations of crystal silt. Some of the linings of the ovoid pores incorporate lenticular domains dissected into cells by bands of micrite (Fig. 6). Similar structures occur in other pores and within the matrix. These structures are "alveolar texture" (cf. Esteban and Klappa, 1983), thought to form by growth of fine-grained crystals or displacement of mud around bundles of root fibers. The association with alveolar texture strengthens the presumption that the lined ovoid pores are rhizoliths and that the branching tubes are root structures. This interval has considerable yellow staining, commonly in solution pores, that may be iron oxides. This is consistent with other indicators of subaerial exposure.

\section{Interpretations: Site $\mathbf{8 7 3}$}

A major focus of ODP Legs 143 and 144 was the history of sealevel changes recorded in central Pacific guyots. As diagenetic fabrics and chemistry can, with a little bit of luck, document postdepositional environments, interpretation should focus on indicators of sea-level history. Water chemistry and temperature are the most indicative parameters.

Cementation and neomorphism by meteoric waters produce lowered $\delta^{18} \mathrm{O}$ and $\delta^{13} \mathrm{C}$ values. The amount of lowering will depend on the degree of fractionation of the waters, the effective rock-water ratios, and the temperature of crystal growth. Reduction of ${ }^{13} \mathrm{C}$ may be particularly marked if soil gases generated by bacteria above the water table were a source of $\mathrm{CO}_{2}$. Negative $\delta^{13} \mathrm{C}$ spikes are considered an excellent marker of fossil vadose zones and thus of subaerial exposure (Allan and Matthews, 1982; Goldstein, 1991).

The clearest signal of sea level at Site 873 comes from the rhizoliths, alveolar textures, and possible root structures in Core 144-873A5R (88.6-89.3 mbsf). These criteria for subaerial exposure, superposed on subtidal limestones, signal a drop in relative sea level, essentially coincident with the top of Subunit IIIA-2 (Lincoln et al., this volume). No isotopic signature of this exposure event was detected; in fact the three cement samples from Core 144-873-5R were among the highest in $\delta^{18} \mathrm{O}(-0.04 \%$ to $+0.66 \%)$. This could reflect evaporation of water from a soil zone, which would concentrate the heavier isotopes.

The cements from Site 873 vary little except in size; PLUC and SOC types (Table 1) are prevalent throughout. These morphologies are not diagnostic, except that they are certainly not typical shallowmarine cements (cf. RC and RC-FIC described below and in Table 1). The simple pyramidal cements (PLUC) appear to have more acute scalenohedral terminations than the typical more equant meteoric calcite cements, although the two would probably be difficult to differentiate in filled pores where terminations are obscured. Round terminations, common in the very finely crystalline PLUC cements, probably reflect dissolution as the last diagenetic overprint. Limpid, equant or bladed calcite crystals, similar to PLUC, occur as primary marine cements formed below the thermocline in the Bahama Banks

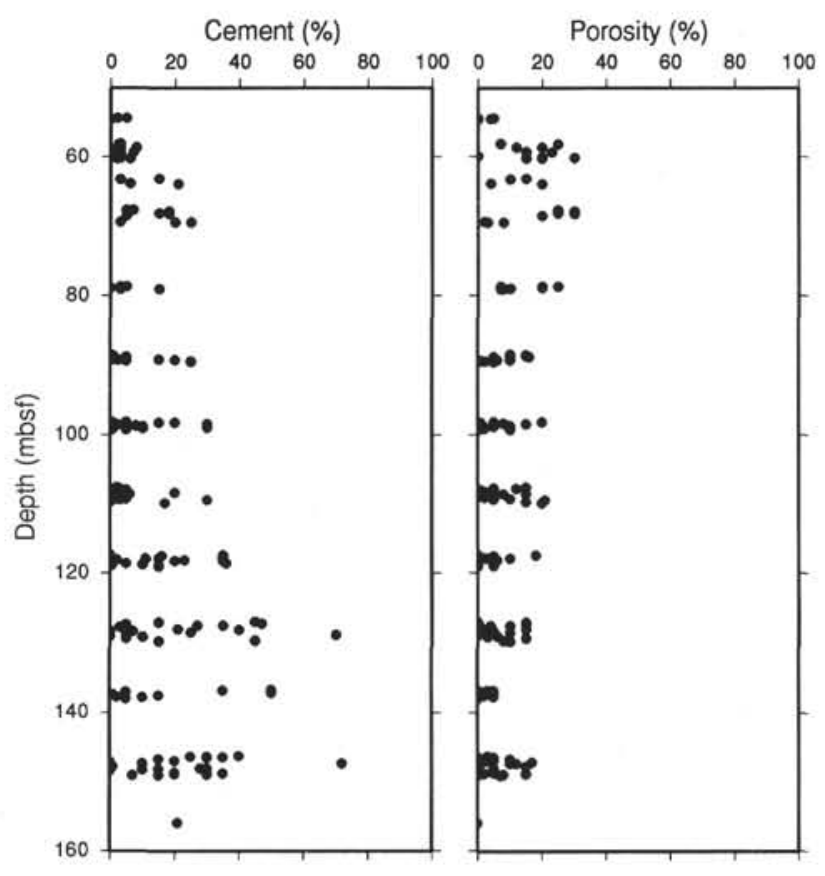

Figure 5. Cement and porosity variations with depth as estimated from 175 thin sections (Site 873). Top of platform is at $54 \mathrm{mbsf}$. From Lincoln et al. (this volume).

(Schlager et al., 1978; Freeman-Lynde et al., 1986). Freeman-Lynde et al. (1986, p. 810) concluded that "isotopic compositions of these deep-marine cements has changed from approximately $-0.6 \% 0 \delta^{18} \mathrm{O}$ and $+1.9 \% 0 \delta^{13} \mathrm{C}$ in the Maastrichtian to about $+2.0 \% 0 \delta^{18} \mathrm{O}$ and $+3.6 \%$ $\delta^{13} \mathrm{C}$ in the Quaternary." The high $\delta^{18} \mathrm{O}$ values of the majority of cements from Site 873 ( $-2 \%$ to $+1 \%$; Fig. $8 \mathrm{~A})$ suggest precipitation from waters with anomalously high ${ }^{18} \mathrm{O}$ or, much more likely, from cold seawater (see below). Cementation could have occurred at any time, or continuously at extremely slow rates, from submergence of the guyot in the latest Maastrichtian (Watkins et al., this volume) or in mid-Maastrichtian ( 70.5 m.y., Wilson et al., this volume) until it was effectively isolated from seawater circulation by accumulation of pelagic ooze, beginning in the early Miocene (Premoli Silva, Haggerty, Rack, et al., 1993; Premoli Silva et al., this volume). The time frame and the oxygen isotopic values recorded by the cements at Site 873 would be consistent with the gradient in isotopic compositions of deep-marine cements suggested by Freeman-Lynde et al. (1986). The SOC cements that postdate or overlap the PLUC cements in time would have formed under similar conditions. More detailed isotopic sampling is needed to substantiate this assumption.

Three intervals of subaerial exposure are indicated at Site 873: two by isotopic evidence and the third by petrology. Exposure to meteoric water was necessarily early in the diagenetic history, before the atoll was submerged. Five cements analyzed that have $\delta^{18} \mathrm{O}$ values between $-2 \%$ and $-7.8 \%$ with generally low ${ }^{13} \mathrm{C}$ probably reflect meteoric cementation. The lowest values occur between 58 and $68 \mathrm{mbsf}$, where matrix and fossils also have relatively low $\delta^{18} \mathrm{O}$ and $\delta^{13} \mathrm{C}$ (Fig. $8 \mathrm{~A})$. Matrix and cements have relatively low isotopic values from 129 to $137 \mathrm{mbsf}$. A third interval of subaerial exposure is indicated by root-related fabrics at $88.6-89.3$ mbsf. A matrix sample from this interval had a $\delta^{13} \mathrm{C}$ value of $-0.83 \%$, suggesting the influence of soil gases. The corresponding $\delta^{18} \mathrm{O}$ value is $-0.62 \%$ indicating considerable evaporative concentration in the vadose zone. The first exposure interval indicated by isotopic depletion at $129-137 \mathrm{mbsf}$ is $40-50 \mathrm{~m}$ below the root-related fabrics, suggesting a separate period of freshwater influx. The upper interval of low isotopic values, probably a phreatic signature, overlies the rooting section by $20-30 \mathrm{~m}$. A sepa- 


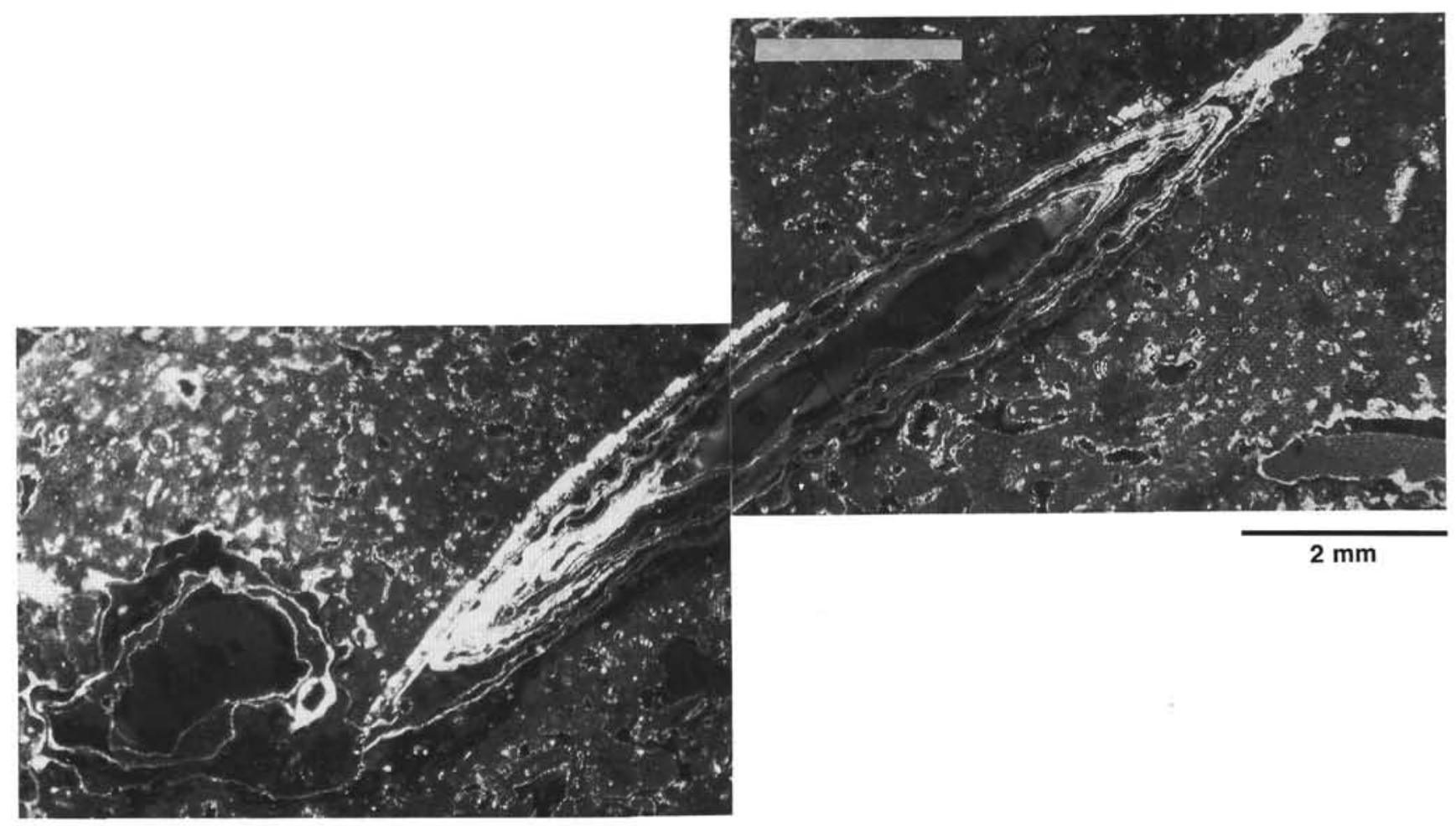

Figure 6. Cement- and micrite-lined rhizolith. Crossed polars. Bright band at top left of rhizolith is a thin mollusk shell; it may have formed a shelter that the root grew into. Scale bar is $2 \mathrm{~mm}$. Sample 144-873A-5R-1, 37-40 cm. From Lincoln et al. (this volume).

rate period of exposure is again indicated, because the roots probably formed in the vadose zone or top of the phreatic zone; they are unlikely to have extended $20-30 \mathrm{~m}$ into the phreatic zone.

The upper interval of quite low $\delta^{18} \mathrm{O}$ and $\delta^{13} \mathrm{C}$ values in matrix, fossils, and cement extends to the top of the platform limestone and into the veneer of phosphatized and manganese-encrusted limestone with mixed pelagic and neritic components (Premoli Silva, Haggerty, Rack, et al., 1993). The covariant lowering of the isotopic values within the fossils and matrix appears to be the signature of at least partial stabilization in meteoric water. The negative $\delta^{13} \mathrm{C}$ indicates subaerial exposure with meteoric-water and possible soil-gas influence that may correspond to the termination of the platform. No unequivocal fabric indicators of exposure were seen at the platform-topelagic transition. The PLUC that formed in deeper, cooler water after submergence of the guyot postdates neomorphism. Cements identified as PLUC with very low ${ }^{18} \mathrm{O}$ at this upper interval (Fig. 8A) may reflect secondary alteration or mistaken cement identity. Alteration in waters with low ${ }^{18} \mathrm{O}$, presumably meteoric, is inconsistent with the inferred post-drowning origin of PLUC. No meteoric cements were recognized, but pore-filling equant, blocky spar, typical of meteoric phreatic cement, might be indistinguishable from pore-filling PLUC. The distinctive acute pyramidal habit of PLUC could not be discerned in the compromise boundaries of filled pores.

Secondary porosity does not have an isotopic signature, unlike neomorphic spar, but is generally easier to relate to cements in time by crosscutting relationships. The PLUC cement is more common in primary intergranular pores (BP) than in secondary pores (MO, VUG), but occurs in all pore types. Thus the fabric-selective leaching of molds and their enlargement to vugs apparently overlapped precipitation of PLUC in time. Fabric-selective leaching of metastable components is a hallmark of meteoric diagenesis, but it is equally probable in undersaturated marine waters between the limit of aragonite saturation and the deeper limit of calcite saturation. Molds and vugs within the manganese-encrusted veneer that contains Paleogene planktonic carbonates must have formed during exposure or early in submergence. If the second possibility could be documented, some measure of the minimum rate of submergence to the aragonite lysocline could be established.

\section{SITES 874 AND 877-THE INNER PERIMETER RIDGE: "REEF AT LAST"}

Sites 874 and 877 , drilled $0.7 \mathrm{~km}$ apart on strike of the inner perimeter ridge of Wodejebato were similar enough in depositional history that they were summarized together (Camoin et al., this volume). The diagenetic histories of these sites also have some strong parallels (Camoin et al., Wyatt et al., and Opdyke et al., all in this volume). There are significant differences, however, and, with the number of independent studies, it would not be surprising if the differences were amplified. In some cases, although the descriptions and the analytical results are similar, the interpretations are not.

Diagenetic features are described in context of lithologic units; overall trends are summarized at the conclusion of this section, followed by interpretation.

\section{Unit I}

Unit I (Figs. 9-10) is the veneer of manganese-encrusted, phosphatic limestone, 0.03-0.11 m thick, in which reworked fragments of platform carbonates are incorporated into Paleogene pelagic carbonate (Watkins et al., this volume). This complicated unit is treated in detail elsewhere (Watkins et al., this volume). It will be considered here only as it bears on the diagenesis of the underlying platform carbonate. 


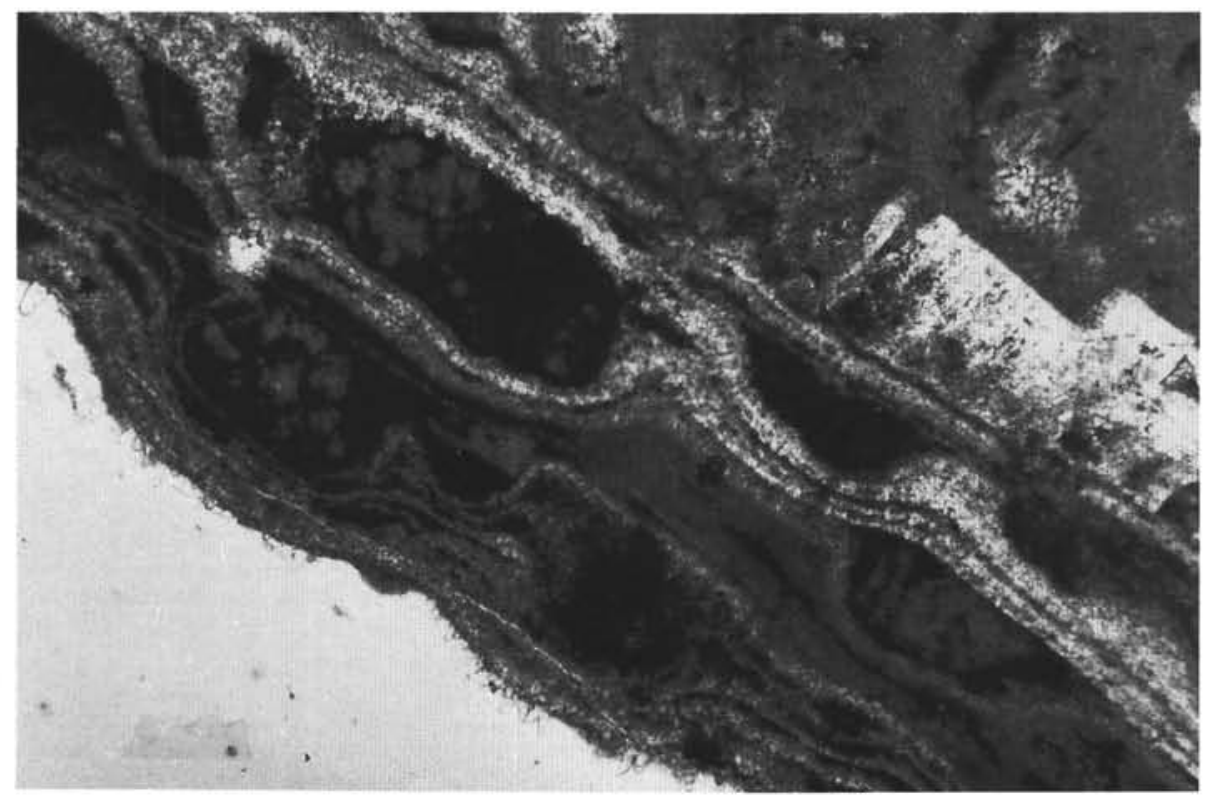

$200 \mu \mathrm{m}$

Figure 7. Probable alveolar texture, attributed to cementation or sedimentation around plant rootlets. Detail of Figure 6. Scale bar is $0.2 \mathrm{~mm}$. Sample 144-873A$5 \mathrm{R}-1,37-40 \mathrm{~cm}$.

\section{Subunit IIA}

Subunit IIA (Figs. 9-10) is red algal-rudist boundstone, replete with stromatoporoids in Hole $874 \mathrm{~B}$, and foraminifer packstone, grainstone, and rudstone, $9.5-11.1 \mathrm{~m}$ thick. It was interpreted as "reef" and perireef sand environment (Camoin et al., this volume).

Cement abundance ranges from $0.5 \%$ to $33 \%$ in primary porosity and $0 \%$ to $15 \%$ in secondary pores, mostly molds, in Hole $874 \mathrm{~B}$ from shore-based thin-section estimates. The smaller thin sections and shorter time available aboard ship produced greater variation ranging from $0 \%$ to $55 \%$. Averages for total cement are $28.7 \% \pm 12.8 \%$ and $26.0 \% \pm 21.4 \%$, respectively. Point counts of cement in Hole $877 \mathrm{~A}$ range from $7 \%$ to $38 \%$, mostly in primary pores; molds contain an average of $2.5 \%$ cement. This is the most thoroughly cemented portion of the platform limestone at any Wodejebato site.

Thick crusts of cloudy, radiaxial cement with sweeping extinction (RC and RC-FIC; Table 1 and Figs. 1-2) are the dominant cements in Subunit IIA, particularly at Site 877 , and are confined to primary pore space. At Site 874 , however, radiaxial cements occur in three samples in Subunit IIA as the second or even third generation of cement, overlying initial variable crusts of clear PLUC cement (Table 1). Moreover, radiaxial cement is no stranger to molds at Site 874; it comprises up to $8 \%$ of the rock volume as fill in secondary porosity. The PLUC (Fig. 4) and its presumed near relative, equant syntaxial overgrowth calcite (SOC) are the only other cement types present; they fill up to $25 \%$ of the bulk volume in primary (BP) pores, and up to $15 \%$ in secondary molds. Some pores are occluded by sediment, mostly pelagic ooze infiltrated during the latest Maastrichtian and $\mathrm{Pa}-$ leogene (Watkins et al., this volume).

Porosity in Subunit IIA ranges from $0 \%$ to $14 \%$ at Site 874 . The average is $2.9 \% \pm 7.0 \%$ from shipboard thin-section estimates and $7.1 \%$ in shore-based estimates; $6.1 \%$ is moldic. Larger scale dissolution porosity is demonstrated by a sediment-filled channel pore 10.1 mbsf (Premoli Silva, Haggerty, Rack, et al., 1993, p. 226, fig. 16). At Site 877 , the range is 0 to $7.5 \%$ in thin-section point counts; the mean is only $3.8 \% \pm 5.1 \% ; 3.6 \%$ is moldic. Cement-filled porosity is $25.8 \%$ $\pm 14.8 \%$.
Neomorphism, in forms that range from coarsely crystalline, clear spar with faint remnants of the original skeletal structure, to delicate replacement that has produced an inclusion-rich calcite image of the original skeleton, has effectively stabilized all the original aragonite that had not been removed by dissolution. The neomorphic stabilization of magnesian calcite was, as is commonly the case, much more subtle; faithful calcite replicas of benthic foraminifers and red algae are the norm at the scale of the petrographic microscope. Dissolution of these skeletons is peripheral and rare.

\section{Subunit IIB}

Subunit IIB is a variety of somewhat muddier lithologies, interpreted as lagoonal and peritidal deposits. Miliolid-gastropod wackestone, locally fenestral and slightly dolomitic (interval 144-874B-2R$2,47-55 \mathrm{~cm}$; Camoin et al., this volume), and rudist-algal packstone, floatstone, and grainstone are the main constituents. Contacts between these lithologies are commonly bored and eroded to produce lithoclasts in the base of the overlying unit. Penecontemporaneous lithification and local dolomitization are indicated. Cement in Subunit IIB at Site 874 makes up from $1 \%$ to $35 \%$ of the bulk volume in primary pore space (mean $=12.4 \% \pm 12.4 \%$ ) and 0 to $15 \%$ in secondary pore space $($ mean $=4.8 \% \pm 4.7 \%)$, mostly in molds. The maximum total is $50 \%$. The average is $17.2 \% \pm 15.9 \%$, about $60 \%$ that in Subunit IIA. At Site 877, total cement in point counts ranges from $0.1 \%$ to $8 \%$, the average is only $3 \%$. The bulk of the cement, $2.3 \%$, is in secondary pores.

Radiaxial cement (RC) was the first generation in 3 of 14 samples sectioned and the second generation in one other. Although most common in primary pore space where it makes up $20 \%-30 \%$ of the bulk volume, $\mathrm{RC}$ also makes up to $13 \%$ of the volume as fill of secondary pores. The rest of the pores are reduced by PLUC, either as the only cement or the last cement, with the exception of the shallowest sample (interval 144-874A-2R-2, 12-17 cm [11.2 mbsf]), where a thin crust of clear cement underlies a thick crust of cloudy RC that constitutes $10 \%$ of the rock. 
A

Fossils
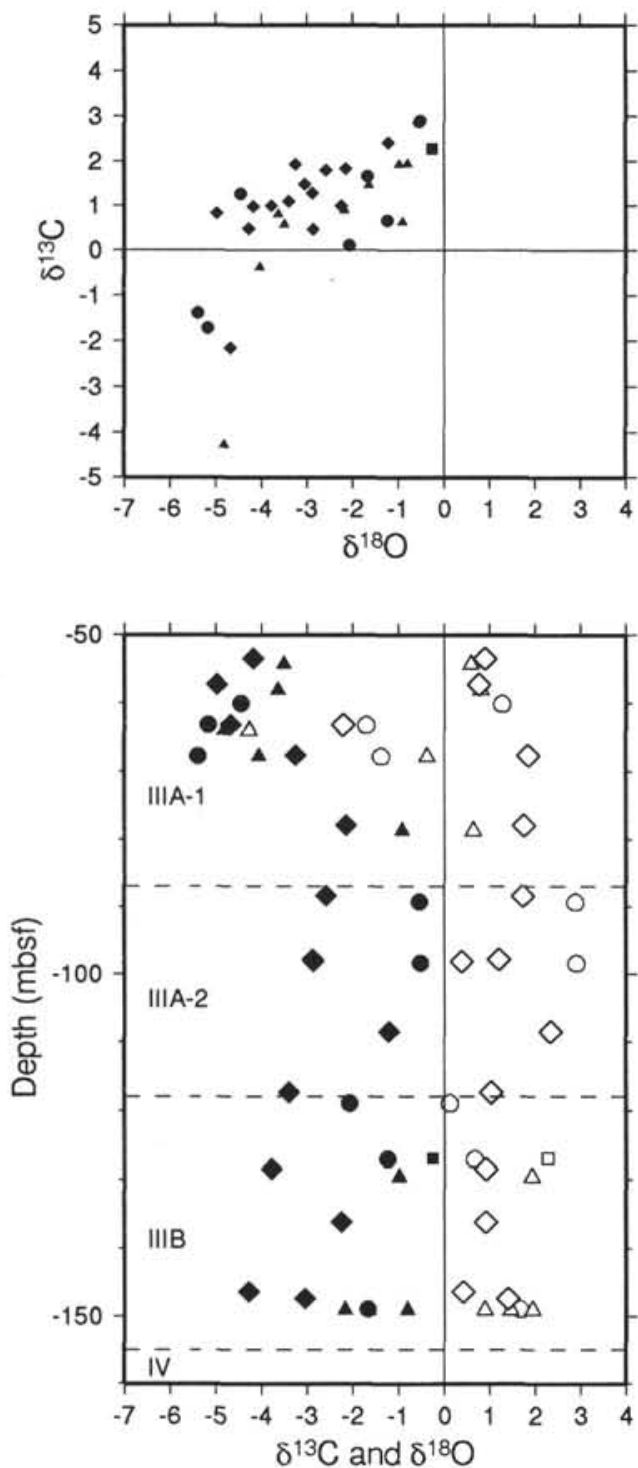

Matrix
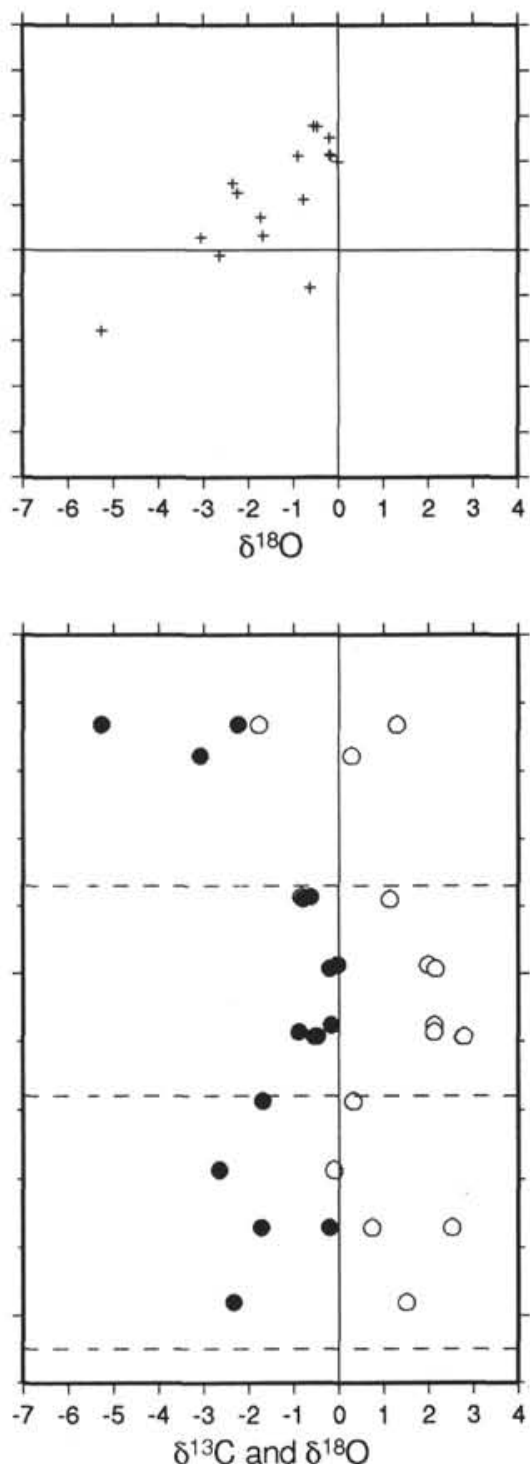

Cement
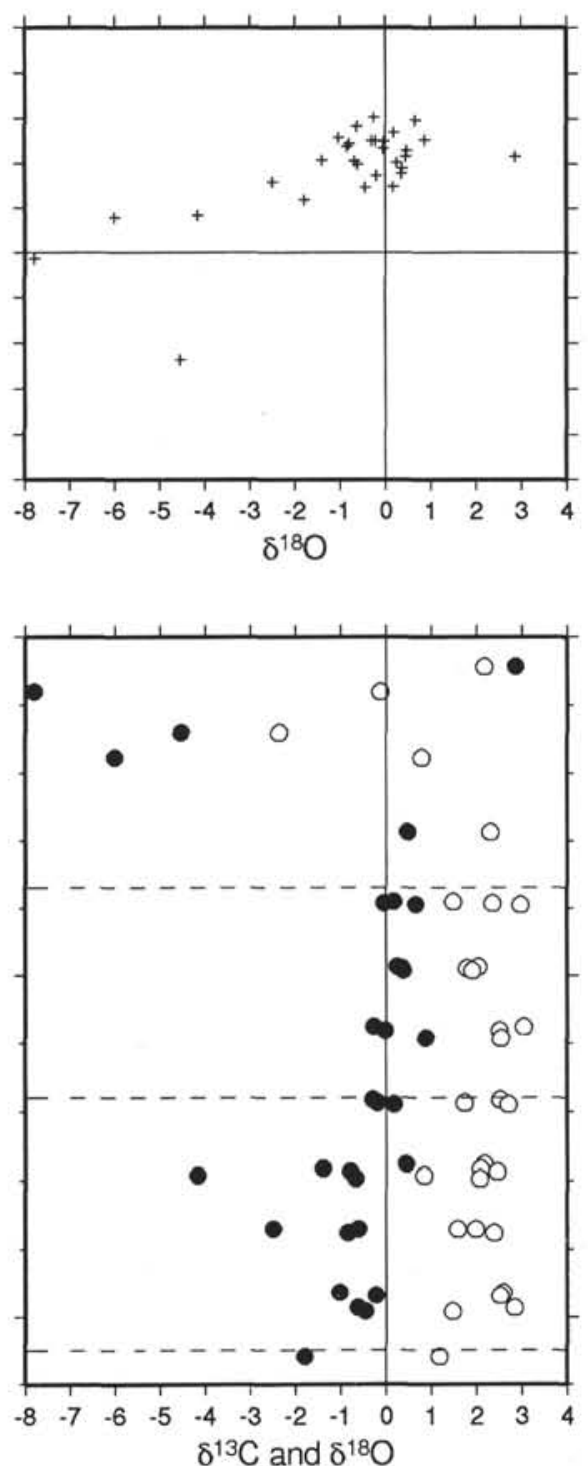

Figure 8. Stable isotopic variations, Site 873. A. Plotted by component (from Lincoln et al., this volume). Closed symbols are $\delta^{18} \mathrm{O}$, open symbols are $\delta^{13} \mathrm{C}$. Symbols for fossils: circles = large benthic foraminifers; triangles = red algae; diamonds = rudists; and squares = dasyclad alga. $\mathbf{B}$. All components, variations wi .h depth. C. Cross plot of stable isotopic compositions.

Subunit IIB is the only interval of the inner perimeter ridge with significant pore occlusion by internal sedimentation. Most samples in Hole 877A show some infiltration of primary and secondary porosity by muddy sediment, typically with sparse ostracodes or benthic foraminifers. Some of the internal sediment contains planktonic biota of latest Maastrichtian through Eocene age (Watkins et al., this volume). The average volume is $4.3 \%$. Only one sample in Hole $874 \mathrm{~B}$ contains significant internal sediment; Sample 144-874B-3R-3, 19 $22 \mathrm{~cm}$, has $15 \mathrm{vol} \%$ of foraminiferal packstone in vugs.

Porosity in Subunit IIB ranges up to $25 \%$ in Hole $874 \mathrm{~B}$ (mean = $10.8 \% \pm 7.4 \%$ in 14 thin-section estimates), but only up to $4 \%$ in Hole $877 \mathrm{~A}$ (mean $=1.8 \% \pm 1.6 \%$ ). Virtually all the porosity is secondary; molds again dominate, but vugs contribute an average of $2 \%$ porosity in Hole 874B. Visible primary porosity was either very low in the original muddy sediment, especially in Hole $877 \mathrm{~A}$, or filled with cement (11.1 vol\% in Hole 874B and 3.9 vol\% in Hole 877A).

\section{Subunit IIC}

The major reef ("reef at last") and adjacent skeletal sands are represented by Subunit IIC, 41.9-77.3 $\mathrm{m}$ of rudist and coralgal boundstone, grainstone, rudstone, and floatstone. It contains the most varied cements and the greatest range of preservation modes. Cement ranges from a trace to $32 \%$ in Hole $874 \mathrm{~B}$ (mean $=11.8 \% \pm 6.85 \%$ ) and from $9 \%$ to $39.5 \%$ in Hole $877 \mathrm{~A}$ (mean $=29.8 \% \pm 12.3 \%$ ). Cements in secondary pore space make up from $0 \%$ to $12 \%$ and $17.5 \%$ of the rock, respectively. Thick crusts of isopachous, cloudy cement (RC) make up as much as $30 \%$ of the rock, exclusively as the first generation. A columnar, bladed cement (CC) with undulose extinction (Table 1 and Fig. 3) is unique to Core 144-877A-5R (Fig. 11). It forms crusts of limpid bladed crystals as the first cement generation or the second, overlying RC. Columnar cement contains an average of $7 \mathrm{~mol} \%$ magnesium (Opdyke et al., this volume). The PLUC is the 
B

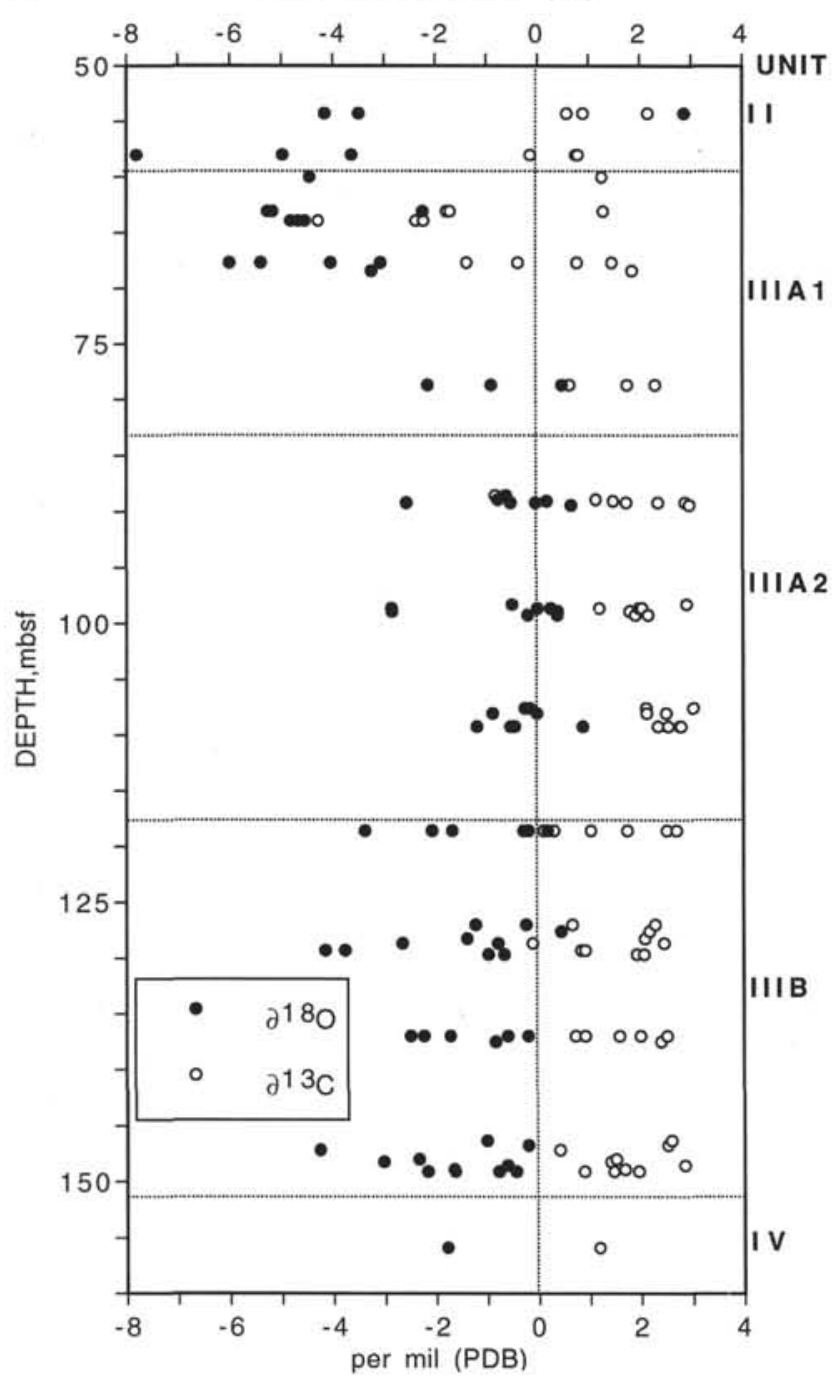

Figure 8 (continued).

second generation cement or, where RC and CC are lacking, directly coats the grains. Clear, syntaxial overgrowths (SOC) compete with PLUC in a few samples.

Porosity in Subunit IIC averages $14.9 \% \pm 8.0 \%$ in Hole $874 \mathrm{~B}$ but only $3.5 \% \pm 4.6 \%$ in Hole $877 \mathrm{~A}$. The range is $0 \%-30 \%$ in Hole $874 \mathrm{~B}$, and 0 to $13 \%$ in Hole $877 \mathrm{~A}$. Molds are virtually the only pore type near the top of the unit in Hole $874 \mathrm{~B}$, but below $57.8 \mathrm{mbsf}$, where abominable recovery provided only six thin-sectioned samples, interparticle porosity (BP) averages $17 \%$ out of an average total porosity of $25 \%$. The paltry porosity in $877 \mathrm{~A}$ is moldic throughout. Up to $37.5 \%$ interparticle porosity and $3.5 \%$ moldic porosity have been filled with cement.

The abundance of cement, which is demonstrably very early, and the resultant low porosity had important consequences for diagenesis of Subunit IIC in Hole 877A. It is by far the most exciting interval diagenetically, paradoxically because of a lack of diagenesis, specifically a lack of neomorphism. In Core 144-877A-5R many caprinid rudists have maintained their original aragonite mineralogy of the thick inner shell layer. This is a rare circumstance. Perhaps even more surprising, the columnar cement (CC; Table 1 and Fig. 3) retains 7 mol\% magnesium. The magnesium content indicates that this is a marine cement, even where it is the second generation, overlying RC. This may be the primary magnesium content, or it may have been partially reduced by diagenesis. The distinction is relevant to the interpretations that follow from the trace-element composition (Opdyke et al., this volume). If this is pristine Maastrichtian marine cement, it is indeed a rare specimen. Its value is further enhanced by cooccurrence with pristine aragonite shells of the caprinid rudists (Opdyke et al., Wilson et al., and Camoin et al., all in this volume).

CC calcite has $680-1500 \mathrm{ppm}$ Sr. Modern marine cements with 7 mol\% Mg contain about $680-420 \mathrm{ppm}$ Sr. This suggests that Maastrichtian seawater may have had a strontium concentration double that of the present oceans (Opdyke et al., this volume). This may be a consequence of reduced precipitation of inorganic aragonite, which normally has about $1 \% \mathrm{Sr}$ in the lattice, in a "calcite sea" (Sandberg, 1983). However, the abundance of rudists at these inner ridge sites and the preservation of their original aragonite mineralogy show that the world was still safe for aragonite-secreting organisms.

In a seeming paradox, the aragonite of the rudists contains 2000 $3000 \mathrm{ppm} \mathrm{Sr}$, about the same as modern aragonite mollusk shells (Opdyke et al., this volume). This demonstrates that mollusks had already developed the capability of discriminating against strontium in secreting their shells.

\section{Subunits IID, IIE, and IIF}

Subunits IID, IIE, and IIF in Hole 874B and the equivalent Subunits IID and IIE in Hole 877A are skeletal grainstone, packstone, and floatstone that were differentiated primarily on the basis of color and secondarily on the basis of changes in constituent abundance (Premoli Silva, Haggerty, Rack, et al., 1993). These units were lumped together as a "sand-shoal facies" by Camoin et al. (this volume). Their combined thickness is $82.8 \mathrm{~m}$ in Hole $874 \mathrm{~B}$ and $72.2 \mathrm{~m}$ in Hole 877A.

Cement volumes in these intervals are comparable to those of the overlying units. Subunits IID, IIE, and IIF in Hole 877B contain $18.7 \% \pm 7.8 \%, 11.0 \% \pm 6.3 \%$, and $7.9 \% \pm 7.2 \%$ cement, respectively. Subunits IID and IIE from Hole $877 \mathrm{~A}$ average $15.2 \% \pm 14.5 \%$ and $28.3 \% \pm 2.9 \%$ cement, respectively.

In contrast to the overlying units, RC and RC-FIC are virtually absent in these units. The only exception is Sample 144-877A-17R-1, $16-19 \mathrm{~cm}$, a foraminifer packstone with $36 \% \mathrm{RC}$ in primary pore space. Elsewhere the first generation cement is PLUC and the second generation is equant, syntaxial calcite overgrowths (SOC) on skeletal grains.

Porosity in these skeletal sand units is modest, but greater than in the overlying units: $18.7 \% \pm 7.8 \%, 11.0 \%+6.3 \%$, and $7.7 \% \pm 7.1 \%$ in Subunits IID, IIE, and IIF in Hole 874B and $29.4 \% \pm 13.5 \%$ (not unduly modest!) and $6.7 \% \pm 11.6 \%$ in Subunit ID and Unit II of Hole $877 \mathrm{~A}$. In $874 \mathrm{~B}$, primary porosity (BP and WP) is dominant, with a few exceptions. The maximum preserved BP is $35 \%$. Intergranular porosity is somewhat greater than moldic porosity in Hole $877 \mathrm{~A}$ ( $5.5 \%$ vs. $3.3 \%)$, but vuggy porosity is dominant with $8.4 \%$ on the average.

Molds and micritization leave little material for observable neomorphism in these intervals.

\section{Summary: Inner Perimeter Ridge}

Some generalizations are evident from the inner perimeter ridge sites. Site 877 shows a striking increase in cement abundance at the sea floor and in the interval between 30 and $50 \mathrm{mbsf}$, the upper part of Subunit IIC, the "lower reef" (Fig. 12B). Other spikes representing a sample or two each are evident to the base of the section. Drilling time probably better represents the degree of lithification, because it 


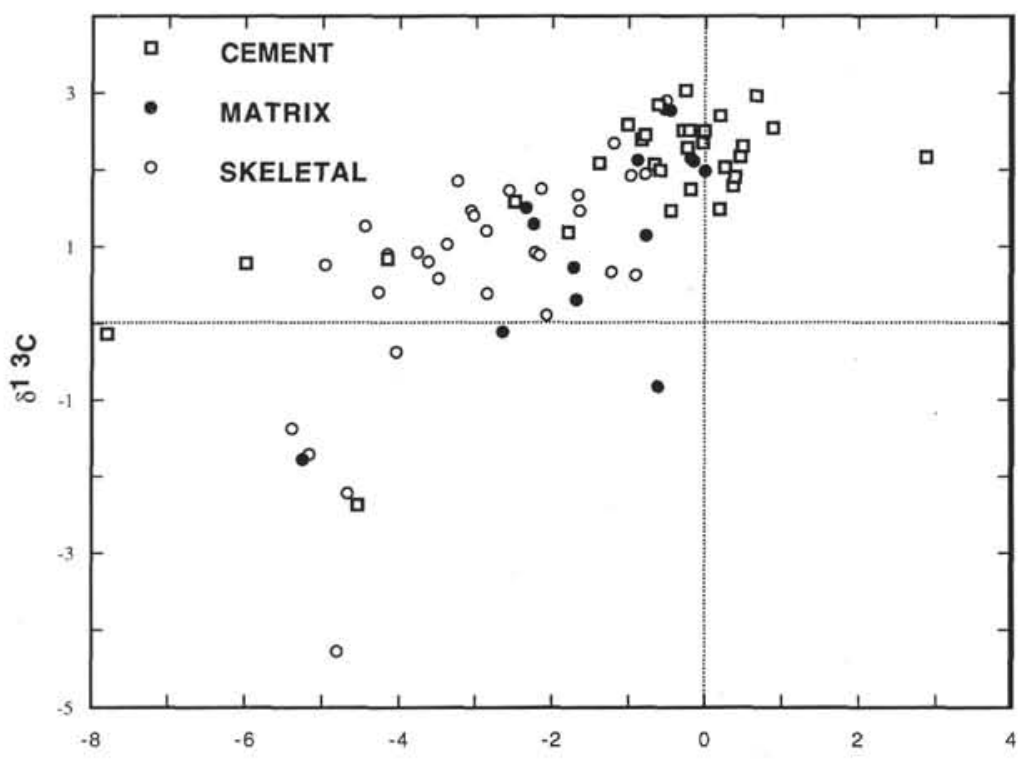

Figure 8 (continued).

$\delta 180$

samples continuously (Fig. 12C). Clearly the upper $50 \mathrm{~m}$ are much better lithified than below. Drilling times are variable but decreasing from 50 to 100 mbsf despite recovery of a few well-cemented samples (Fig. 12B). The drill bit virtually fell through the rest of the platform limestone, with a slight stiffening in the bases of Subunits IID and IIE (Fig. 12C). The focus of the cement shifts from preferentially in secondary pores in the upper $30 \mathrm{~m}$ to almost exclusively in primary pores below 50 mbsf (Fig. 12A).

Porosity increases dramatically in the skeletal sands of the lower half of the core (Fig. 9). Drilling times (Fig. 12C) suggest that the interval between 65 and $105 \mathrm{mbsf}$, where fragmentary recovery precluded adequate porosity measurements, was porous between wellcemented layers. No borehole logs were run at this site.

Changes in porosity and cement are less systematic and dramatic in Hole 874B (Figs. 10 and 13). Cement shows no clear trend, but porosity increases gradually, although irregularly, downward. The zone of minimal recovery from about 85 to $125 \mathrm{mbsf}$, essentially Subunit IID, shows a greatly expanded caliper log (off scale), decreased density (about $2.0 \mathrm{~g} / \mathrm{cm}^{3}$ ), and very low resistivity (Camoin et al., this volume; Fig. 3), clearly signaling a poorly cemented, highly porous interval.

\section{Isotopic Data}

Abundant isotopic data are available from these two sites (Appendix and Tables 2-3) through the efforts of Opdyke et al. (this volume; Site 877), Wyatt et al. (this volume; Site 874), Camoin et al. (this volume; Sites 874 and 877), and J.M. Lincoln (unpubl. data; Site 874). Wyatt et al. and Wilson et al. (both in this volume) also report ${ }^{87} \mathrm{Sr} /$ ${ }^{86} \mathrm{Sr}$ ratios. Plots of stable isotopic data against depth show no prolonged trends; rather a series of low $\delta^{18} \mathrm{O}$ spikes mark the profiles (Figs. 13-15). Scatter plots of all data (Figs. 16-17) from each site show the degree of covariance between $\mathrm{C}$ and $\mathrm{O}$.

Wyatt et al. interpreted intervals of relatively low ${ }^{18} \mathrm{O}$ in their profiles as indicative of diagenesis in meteoric water (shaded zones; Fig. 13C). This appears the best explanation, although no equivalent negative spike in $\delta^{13} \mathrm{C}$ is present, and good petrographic criteria are lack- ing (Wyatt et al., this volume). The upper two zones at 0 and $9 \mathrm{mbsf}$ are not separated by deflections to more positive values. This may be an artifact of poor core recovery, but the two zones could equally well be a single zone $10 \mathrm{~m}$ thick. The corresponding meteoric lens would not be exceptionally thick, unless the site was at its seaward edge. The intervals noted by Wyatt et al. (this volume) are still plainly visible when all data are plotted vs. depth (Fig. 14). The uppermost deflection is the most pronounced; however, no reduction occurs in ${ }^{13} \mathrm{C}$, which would greatly strengthen the case for meteoric influence in general and subaerial exposure in particular. It is possible that relatively short periods of exposure or unfavorable climate prevented formation of a soil profile. Alternatively, erosion may have removed the soil zone without removing evidence of exposure within the meteoric phreatic zone.

The distribution of isotopic values with depth from Site 877 contains many more data and shows the same general form as Site 874, but with less-pronounced excursions (Fig. 15). Diagnostic $\delta^{13} \mathrm{C}$ excursions to low values are again lacking. Low $\delta^{18} \mathrm{O}$ values at both sites give a hint of meteoric influence at about $40 \mathrm{mbsf}$ and at the sea floor.

Plots of isotopic composition of rudists at all sites $(873,874$, and 877) show a distinctive pattern of alteration (Fig. 18). The aragonitic rudists, which should reflect Maastrichtian seawater values (AlAasm and Veizer, 1986), show considerable scatter about mean values of $-1.34 \% \pm 1.16 \%$ for $\delta^{18} \mathrm{O}$ and $+2.95 \% \pm 1.37 \%$ for $\delta^{13} \mathrm{C}$ (Table 3). Remarkably, five values from Site 877 plot with less than $1 \%$ scatter at $4.8 \% \delta^{13} \mathrm{C}$ and $-1.2 \% \delta^{18} \mathrm{O}$ (Camoin et al., this volume). This cluster could be the best value for Maastrichtian near-surface seawater. It compares reasonably well with two values that average $-2.2 \%$ $\delta^{18} \mathrm{O}$ and $+3.55 \% \delta^{13} \mathrm{C}$ from aragonitic rudists in the Upper Cretaceous of Texas (Al-Aasm and Veizer, 1986, p. 764) and an estimate of $-2 \% \delta^{18} \mathrm{O}$ and $+4 \% \delta^{13} \mathrm{C}$ as the original composition of presumed calcitic portions of Aptian rudists from Texas (Moldovanyi and Lohmann, 1984, p. 978). The "well preserved" rudists lie within the scatter shown by the aragonitic rudists, although the mean $\delta^{18} \mathrm{O}$ of $2.53 \% \pm 0.53 \%$ is $1.2 \%$ lower (Table 3 ). Camoin et al. (this volume) observed that those rudists with good mimicking of the original shell 


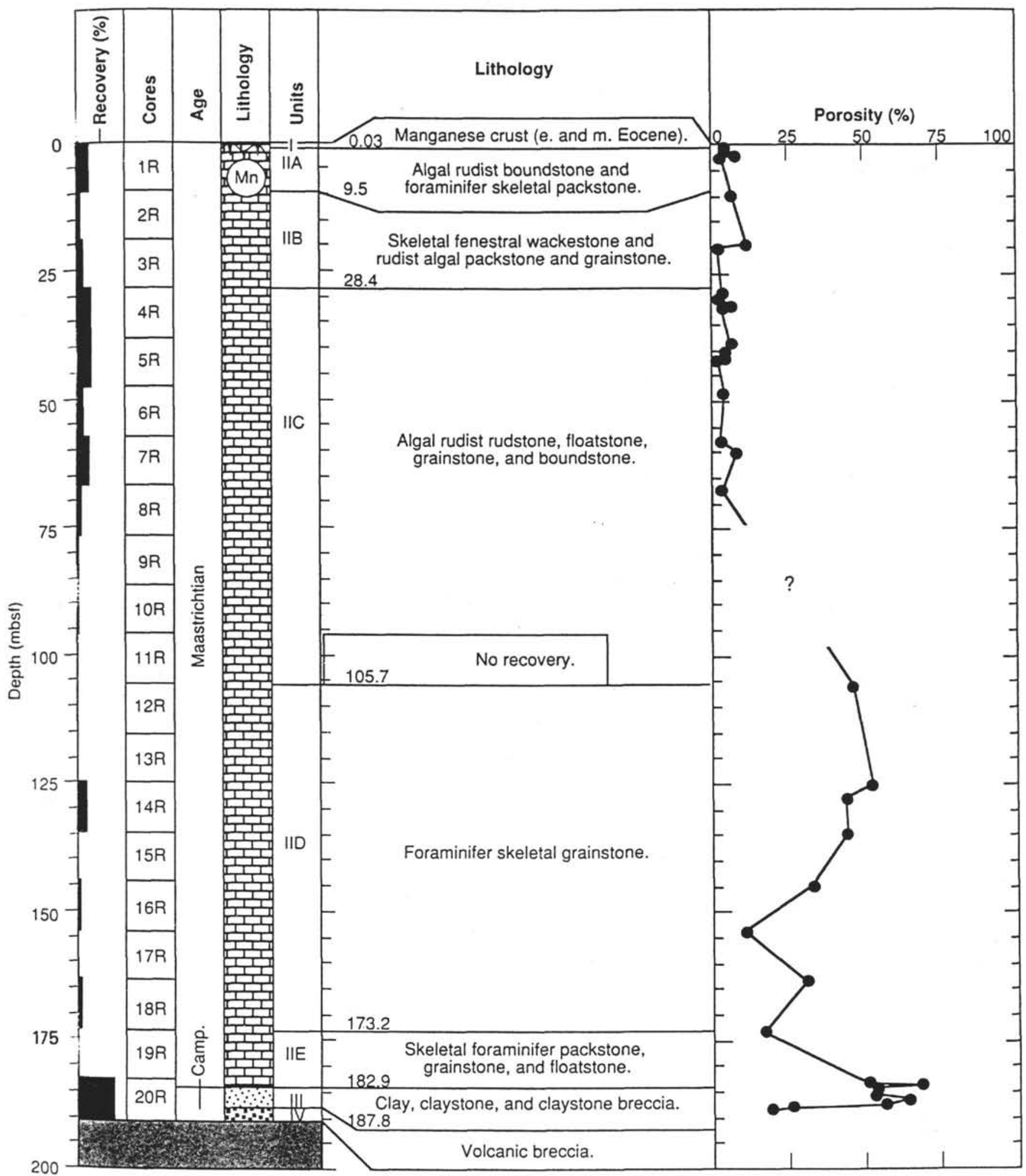

Figure 9. Lithology and porosity variations, Site 877. From Premoli Silva, Haggerty, Rack, et al. (1993, p. 289).

structure through diagenesis preserve the original isotopic signature. Calcitic rudists are thought to be exclusively calcitized aragonite layers of caprinids. They show a shift toward lower values of both isotopes, a common thumbprint of meteoric alteration. The catchall group, "rudists, general," which are all values labeled simply "rudists" by various workers, trace a rather dramatic shift from within the field of pristine aragonitic rudists to quite depleted $\delta^{18} \mathrm{O}$ values. This trend probably reflects the varying degrees of neomorphism seen in the better identified samples.

Most ${ }^{87} \mathrm{Sr} /{ }^{86} \mathrm{Sr}$ data from well-preserved skeletons and cements within the upper part of Hole 874B (Fig. 13) and in Hole 877A (Fig. $15 B)$ show little deviation from values consistent with the Maas- 


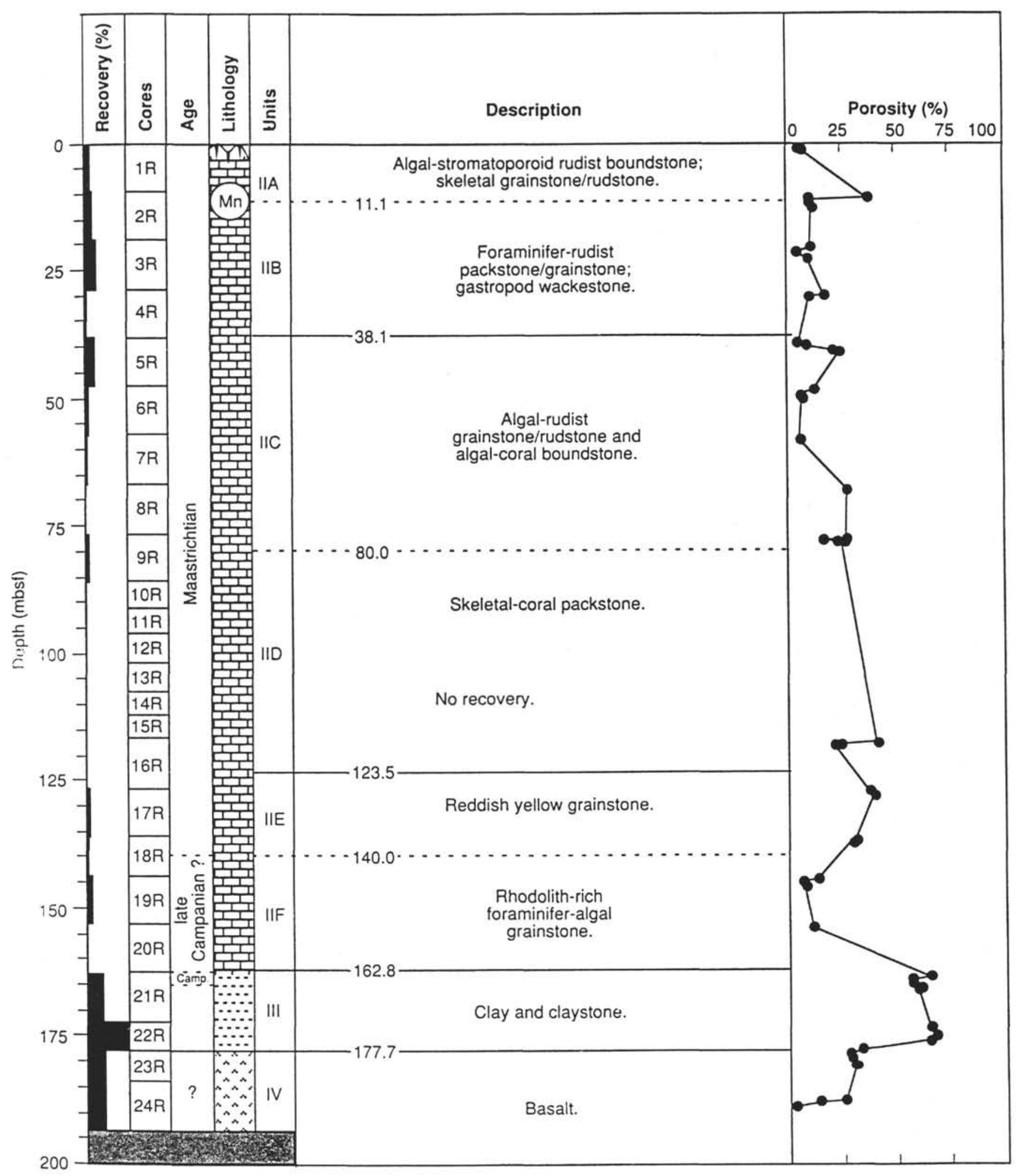

Figure 10. Lithology and porosity variations, Hole 874B. From Premoli Silva, Haggerty, Rack, et al. (1993, p. 221). 


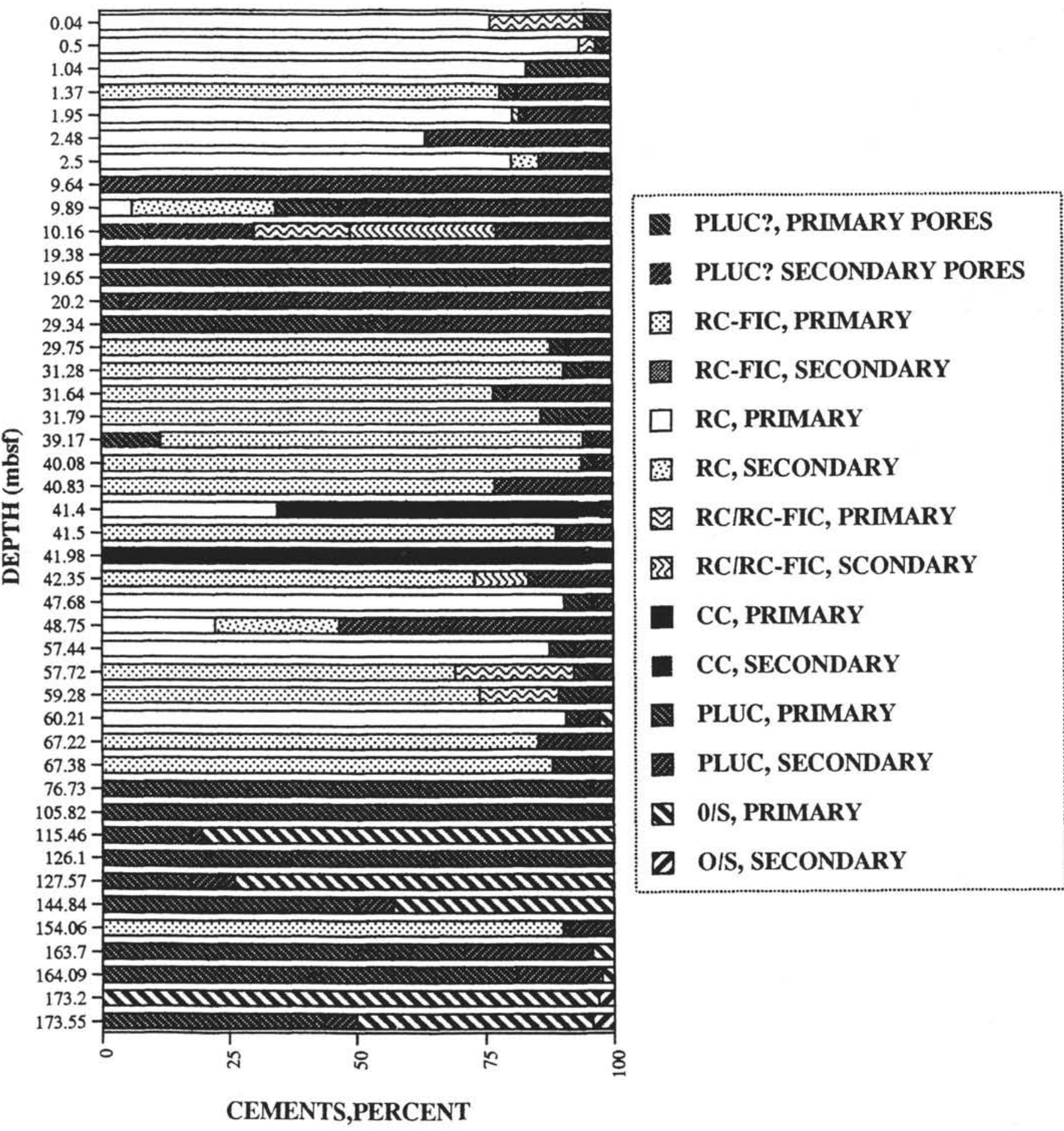

Figure 11. Cement variations with depth at Hole 877A. After Opdyke et al. (this volume).

trichtian stratigraphic age (Premoli Silva et al., this volume). A few cements and a number of "matrix" samples (i.e. poorly preserved, cemented grainstones in which cement could not effectively be isolated) have much more radiogenic strontium, with ${ }^{87} \mathrm{Sr} /{ }^{86} \mathrm{Sr}$ ratios as high as 0.70856 (Fig. 15B). These samples are from 0 to $50 \mathrm{mbsf}$, where they constitute a small percentage of the samples, and from
120 to $180 \mathrm{mbsf}$ where virtually all $\mathrm{Sr}$ isotope ratios are relatively radiogenic (Wilson et al., this volume). An offset to lower ratios of about 0.707730 at 140 mbsf in Hole 874B (Fig. 13) is taken as the Campanian/Maastrichtian boundary (Wyatt et al., this volume), a location consistent with the biostratigraphy (Erba et al., this volume). 


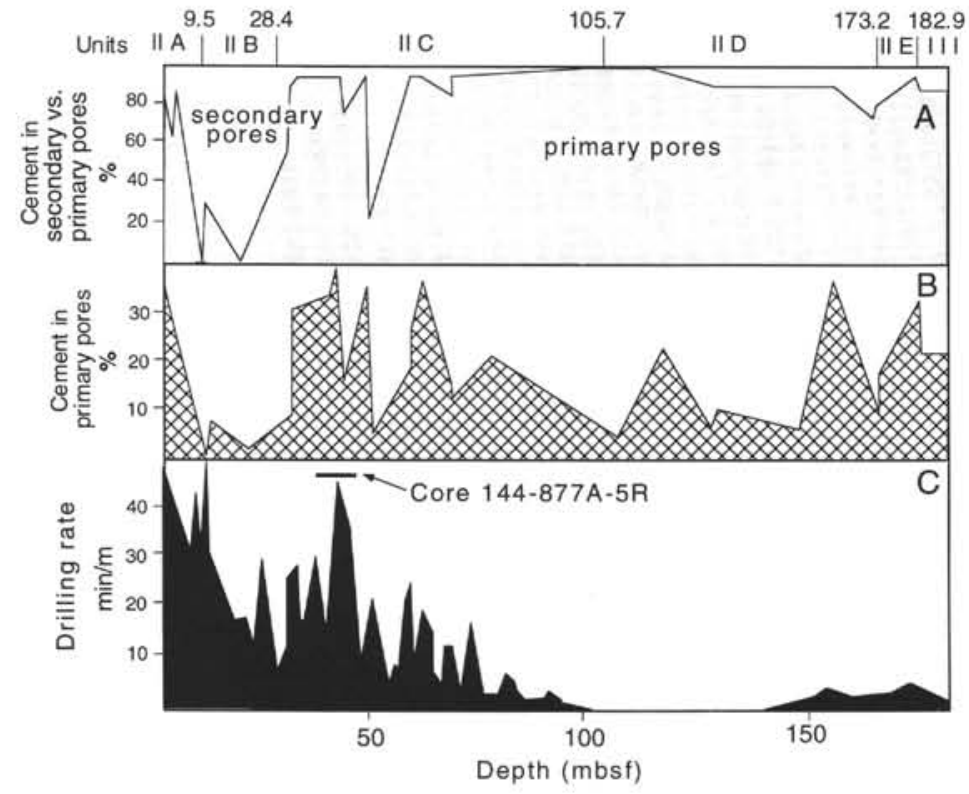

Figure 12. Cement abundance and drilling time with depth in Hole 877A. A. Distribution of cements between primary (BP, WP) and secondary (MO, some VUG) pores. B. Cement as percentage of bulk volume. C. Drilling time: minutes to penetrate $1 \mathrm{~m}$. From Opdyke et al. (this volume).

Table 2. Summary of stable isotopes in cements.

\begin{tabular}{|c|c|c|c|c|c|c|c|c|c|c|}
\hline & \multicolumn{2}{|c|}{$\mathrm{CC}$} & \multicolumn{2}{|c|}{ PLUC } & \multicolumn{2}{|c|}{ PLUC (minus extremes) } & \multicolumn{2}{|c|}{ RC } & \multicolumn{2}{|c|}{ RC-FIC } \\
\hline & $\delta^{13} \mathrm{C}$ & $\delta^{18} \mathrm{C}$ & $\delta^{13} \mathrm{C}$ & $\delta^{18} \mathrm{O}$ & $\delta^{13} \mathrm{C}$ & $\delta^{18} \mathrm{O}$ & $\delta^{13} \mathrm{C}$ & $\delta^{18} \mathrm{O}$ & $8^{13} \mathrm{C}$ & $\delta^{18} \mathrm{O}$ \\
\hline Mean & 2.65 & -2.17 & 2.11 & -0.93 & 2.19 & -0.74 & 2.07 & $-1,19$ & 2.35 & -1.50 \\
\hline & 0.58 & 0.50 & 0.60 & 1.50 & 0.48 & 0.82 & 0.48 & 0.78 & 0.38 & 1.87 \\
\hline$N$ & 8 & & 63 & & 59 & & 16 & & 6 & \\
\hline Maximum & 2.88 & -1.60 & 3.13 & 2.87 & 3.13 & 1.11 & 2.98 & -0.12 & 2.77 & -0.34 \\
\hline Minimum & 1.46 & -2.32 & -0.14 & -7.80 & 1.18 & -2.49 & 1.22 & -3.32 & 1.97 & -5.21 \\
\hline
\end{tabular}

Notes: See Table 1 for definitions of cements. $\delta^{18} \mathrm{O}$ values of PLUC are less than -4 and greater than $+2 . \mathrm{SD}=\mathrm{standard}$ deviation, and $N=$ number of analyses.

Table 3. Summary of stable isotopes in rudists..

\begin{tabular}{|c|c|c|c|c|c|c|c|c|}
\hline & \multicolumn{2}{|c|}{ Rudists } & \multicolumn{2}{|c|}{ Aragonite rudists } & \multicolumn{2}{|c|}{ Well-preserved rudists } & \multicolumn{2}{|c|}{ Calcite rudists } \\
\hline & $\delta^{13} \mathrm{C}$ & $8^{18} \mathrm{O}$ & $\delta^{13} \mathrm{C}$ & $\delta^{18} \mathrm{O}$ & $\delta^{13} \mathrm{C}$ & $\delta^{18} \mathrm{O}$ & $\delta^{13} \mathrm{C}$ & $\delta^{18} \mathrm{O}$ \\
\hline Mean & 1.82 & -3.35 & 2.95 & -1.34 & 2.91 & -2.53 & 1.19 & -3.51 \\
\hline SD & 0.68 & 2.66 & 1.37 & 1.16 & 0.47 & 0.25 & 0.84 & 0.97 \\
\hline$N$ & 13 & & 29 & & 10 & & 26 & \\
\hline Maximum & 3.13 & 0.07 & 6.35 & 1.28 & 3.87 & -1.99 & 2.34 & -1.20 \\
\hline Minimum & 0.92 & -7.64 & 0.76 & -2.97 & 2.40 & -2.87 & -2.22 & -4.97 \\
\hline
\end{tabular}

Note: $\mathrm{SD}=$ standard deviation, and $\mathrm{N}=$ number of analyses.

\section{SITES 875 AND 876-OUTER PERIMETER RIDGE}

The holes on the outer perimeter ridge of northeastern Wodejebato sampled 126-145 m of poorly cemented, leached skeletal sands punctuated by a thin interval of lithoclasts in a matrix of mud and rhodoliths (MIMSP unit of Enos et al., this volume). Although these skeletal sands are lithologically very similar to Subunits IID, IIE, and IIF from Sites 874 and 877 , they are now known to be appreciably younger and correlative to Subunits IIA and IIB of the inner perimeter ridge sites (Premoli Silva et al, and Enos et al., both in this volume).

Just as the lithologies of these two sites are distinctly repetitious, except for the comic relief provided by MIMSP (see revised interpretation by Enos et al., this volume), so are the diagenetic features. The lower and upper skeletal sands, LPSC and UPSC, respectively, are extremely porous, highly leached, and lightly cemented with a relatively simple cement pattern.

Cement in the lower unit (LPSC) averages $12.9 \% \pm 10.3 \%$ of the bulk volume from the two sites; $78 \%$ of the cement is in primary pores and $22 \%$ in secondary pores. Three quarters of the cement is PLUC. The remainder, $22 \%$ to be exact, is medium crystalline, equant calcite overgrowths, SOC, on echinoderms, mollusks, and foraminifers. Although SOC appears to overgrow PLUC where the relationships are evident, it is confined to primary intergranular pores. This is presumably because, as overgrowths on grains, SOC cement is constrained to nucleate on the surface of a grain, in an intergranular pore that it simply hasn't outgrown. Cement in UPSC is only $6.7 \%$ of the bulk volume; less than $1 \%$ occurs in molds, the remainder is in primary pores. The PLUC is dominant, and the SOC is minor. 


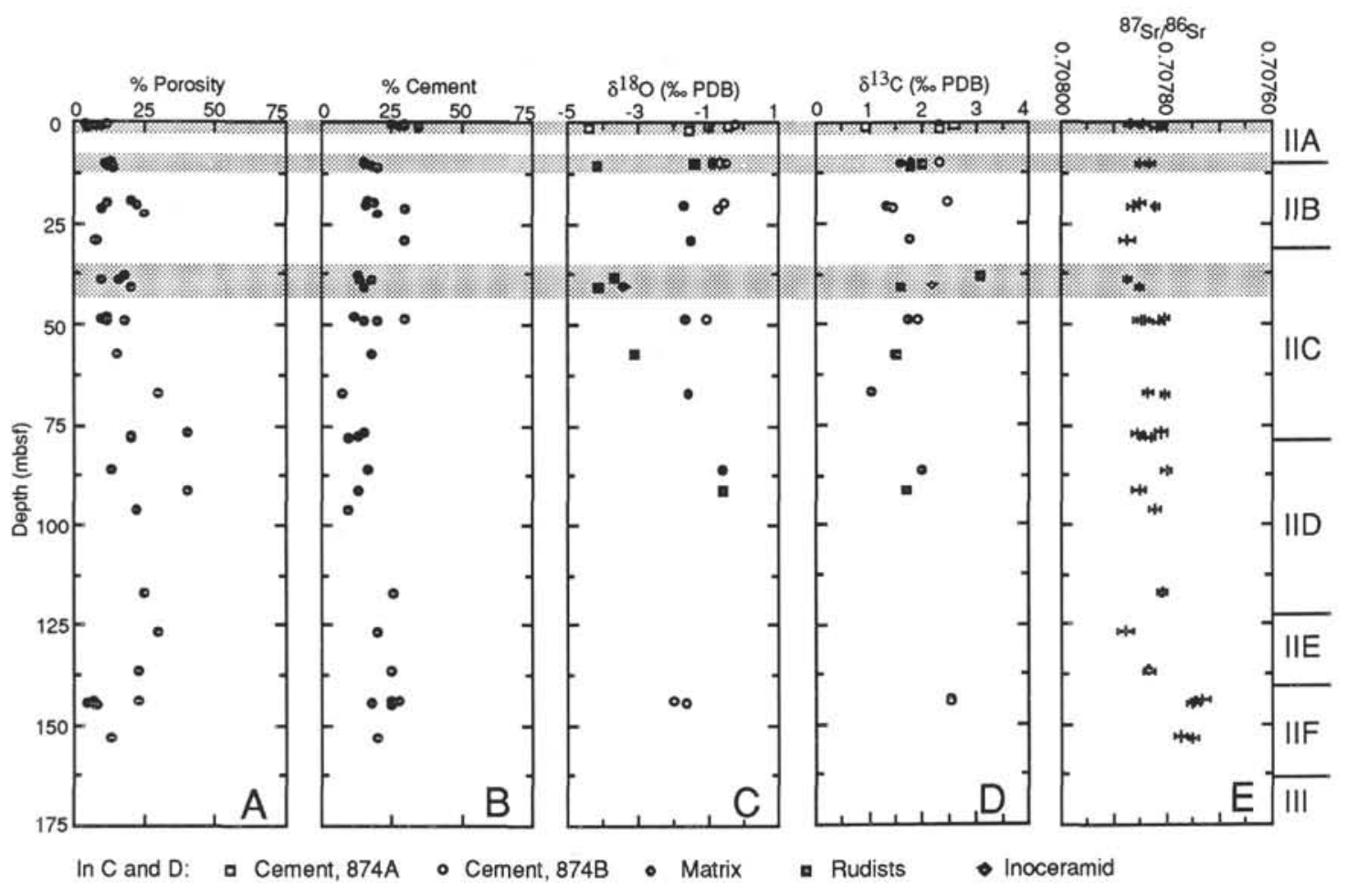

Figure 13. Variations of diagenetic parameters with depth, Site 874. Shaded intervals are those with evidence of interaction with meteoric water. From Wyatt et al. (this volume).

The porosity of the lower unit (LPSC) averages $30.9 \% \pm 7.5 \%$ in physical properties measurements (Premoli Silva, Haggerty, Rack, et al., 1993, p. 267, 280). Thin-section estimates are $25.4 \% \pm 12.4 \%$. Secondary pores, molds and few vugs contribute $53 \%$ of the total porosity. Porosity is even higher in the upper unit (UPSC): $39.4 \% \pm$ $6.3 \%$. Secondary porosity, mostly molds, is $14.5 \%$ of bulk volume; primary intergranular porosity is $24.9 \%$. Some larger cavities, greater than the diameter of the core barrel, are inferred from facing surfaces, typically concave, yellow stained, and cement lined, on adjacent unrotated core pieces. These could be from opposite sides of a cavity that the bit penetrated; this would help explain the severe mastication of the recovered rocks (Enos et al., this volume). No cavities large enough to cause a noticeable drop in the drill bit were encountered.

The muddier middle unit (MIMSP) has 23 vol\% cement. In $30 \%$ of the samples, the initial cement was radiaxial fibrous calcite (RCFIC); the only occurrence of $\mathrm{RC}$ recovered from the outer ridge. It constitutes $22.7 \%$ of the bulk volume where present; $3 \%$ of this bulk volume is secondary porosity. The rest of the cement in this unit is PLUC, with crystals larger than normal. Internal sediment, packstone with foraminifers and skeletal fragments, overlies the RC in several samples. A second generation of interval sediment, an ostracode packstone, overlies PLUC in Sample 144-876A-11R-2, 14-23 cm. The porosity of the MIMSP averages only $4 \%$ molds and $2.6 \%$ primary. Some of the moldic porosity and internal sediment described in the Initial Reports (Premoli Silva, Haggerty, Rack, et al., 1993) are now interpreted as clasts with inherited (pre-erosion) moldic porosity from the inner perimeter ridge (Subunit IIB). Upon deposition, the molds were filled by the background sediment (Enos et al., this volume).

No downhole logs were run at these sites because of bad hole conditions, resulting from the extreme porosity, and lack of time. No isotopic data are available.

\section{MANGANESE-IMPREGNATED PELAGIC LIME- STONE}

Laminated, "stromatolitic" manganese crusts, which penetrated the rim of the platform limestones and the overlying rubble of limestone fragments, and lithified pelagic ooze veneer the platform limestones at all Wodejebato sites.

Recovered thickness ranged from $3 \mathrm{~cm}$ in Hole $877 \mathrm{~A}$ to $14 \mathrm{~cm}$ in Holes $875 \mathrm{C}$ and $873 \mathrm{~B}$. From within this interval and related pelagic infiltration, no fewer than 14 distinct episodes of pelagic sedimentation have been differentiated that range in age from latest Maastrichtian to late Eocene. Watkins et al. (this volume) have dissected this crust far beyond our poor power to add or detract.

The most striking contact recovered between this unit and the underlying limestone was in interval $144-876 \mathrm{~A}-1 \mathrm{R}-1,22-41 \mathrm{~cm}$. A vertical manganese-stained contact extends from near the top of the piece, $0.25 \mathrm{mbsf}$, to $0.39 \mathrm{mbsf}$ where it flattens and passes out of the core (Fig. 19; Premoli Silva, Haggerty, Rack, et al., 1993, p. 266). The pelagic limestone is early Eocene in this case (Watkins et al., this volume; Fig. 6). Clasts of pelagic limestone at the contact are possibly as old as early Paleocene. Pelagic mud infiltrated interparticle pores and a few skeletal molds near the contact and formed perched sediment at least $67 \mathrm{~cm}$ below the uppermost contact of UPSC $(0.75$ mbsf).

\section{INTERPRETATIONS}

Regardless of the interpretation of the vertical contact with the manganese-encrusted limestone just described, this occurrence shows that the platform limestones were lithified, eroded, and 


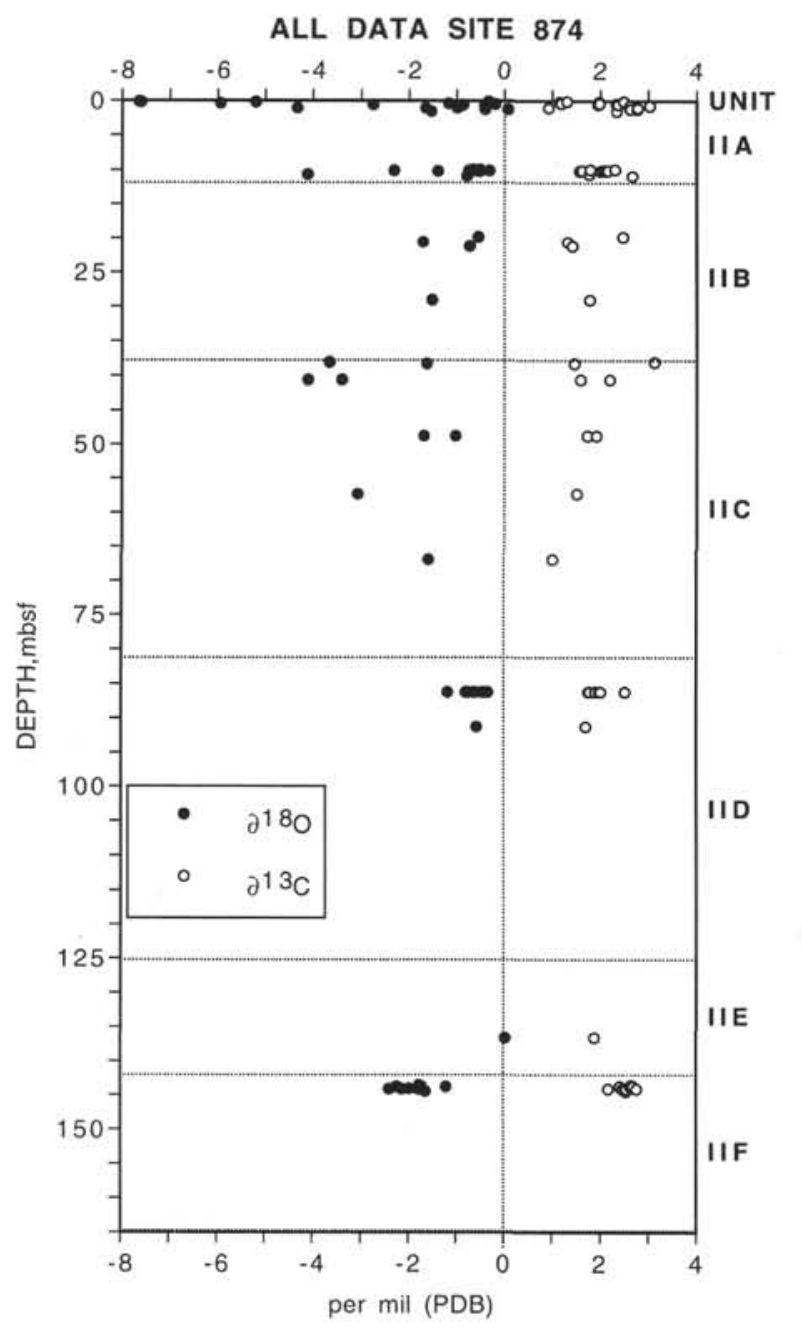

Figure 14. Stable isotopic variations in all components with depth, Site 874.

leached to form molds by perhaps the Paleocene; certainly by early Eocene. At inner perimeter ridge sites, platform limestone pebbles within the pelagic limestone and vugs infiltrated by pelagic ooze to $20 \mathrm{mbsf}$ attest to the same events. These events need not have occurred before drowning of the atoll; it is possible that they are deepmarine diagenetic events.

The preferred explanation is that the vertical surface in interval 144-876A-1R-1, 22-41 cm (Fig. 19) represents a microkarst formed under subaerial conditions prior to drowning of the atoll (Enos et al., this volume, consider alternative interpretations). A surface with perhaps a meter or more of relief with unconnected depressions and bioencrusted knobs was observed over an appreciable area of the sea floor during video surveys to select drilling sites on the perimeter of Wodejebato. If this is a karst surface, as it appears, a microkarst with at least $1.3 \mathrm{~m}$ of relief is present on the perimeter ridge of Wodejebato. Calculations on the rates of meteoric dissolution in a tropical climate suggest that removal of $1.3 \mathrm{~m}$ of limestone could occur in half a million years (Enos et al., this volume, appendix). Note that karst formation at these sites, the deepest part of the guyot cored, would imply exposure of the entire limestone cap of the guyot and a corresponding drop in sea level of at least $54 \mathrm{~m}$, the difference in elevation of the top of platform limestones from the perimeter of the guyot to the interior (Site 873).

A larger scale of karst formation may be indicated by the trough that separates the outer and inner perimeter ridges, although this is
A

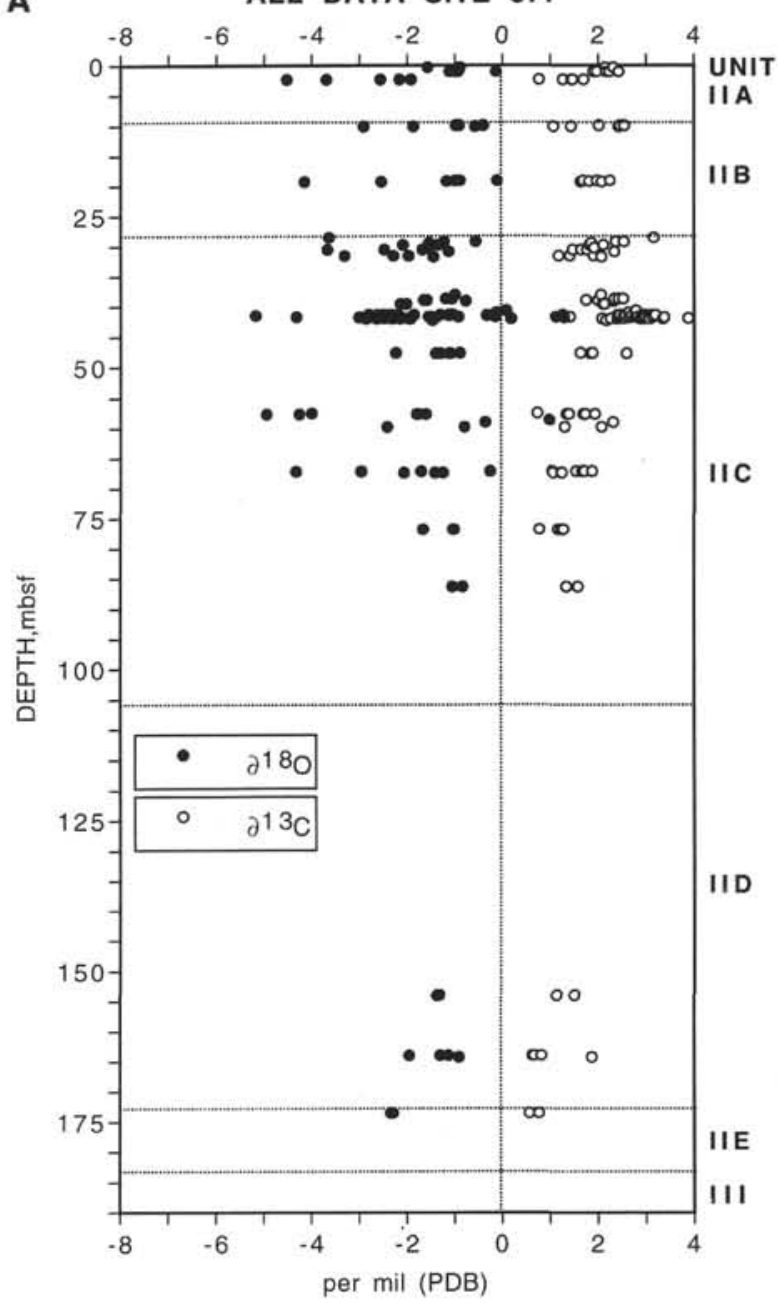

Figure 15. A. Variations in stable isotopic composition with depth, Site 877. B. Variations in ${ }^{87} \mathrm{Sr} /{ }^{86} \mathrm{Sr}$ with depth at Site 877 . Closed triangles = cement, open triangles $=$ vein calcite, closed circles $=$ matrix , and open circles $=$ skeletons. From Wilson et al. (this volume).

not the favored interpretation (Enos et al., this volume). Formation of the trough, which may involve local erosion of up to $70 \mathrm{~m}$ of limestone, would require 11-24 m.y., using the same assumptions as above (Enos et al., this volume, appendix). This time interval is between three to eight times the time available before carbonate platform drowning (Watkins et al., this volume).

All sites from which stable isotopic data are available $(873,874$, and 877 ) show lower ${ }^{18} \mathrm{O}$ toward the top of the platform carbonates (Figs. 8 and 14-15). This is a typical signature of meteoric waters, just where the strongest overprint of marine diagenesis might be expected during drowning of the atoll. Some key items that could strengthen the case for subaerial exposure are missing, despite diligent searches. No definitive petrographic criteria for exposure were found at the top of the platform carbonates. No marked depletion of ${ }^{13} \mathrm{C}$, a definitive fingerprint of subaerial exposure (Allan and Matthews, 1982; Goldstein, 1991), accompanied the depletion of ${ }^{18} \mathrm{O}$. A possible explanation is incomplete development of soils or removal by erosion.

There is good evidence for subaerial exposure at other levels unrelated to that at the top of the platform. Rhizoliths, alveolar texture, and possible root casts were identified in Hole 873 from 88.6 to 89.3 
B
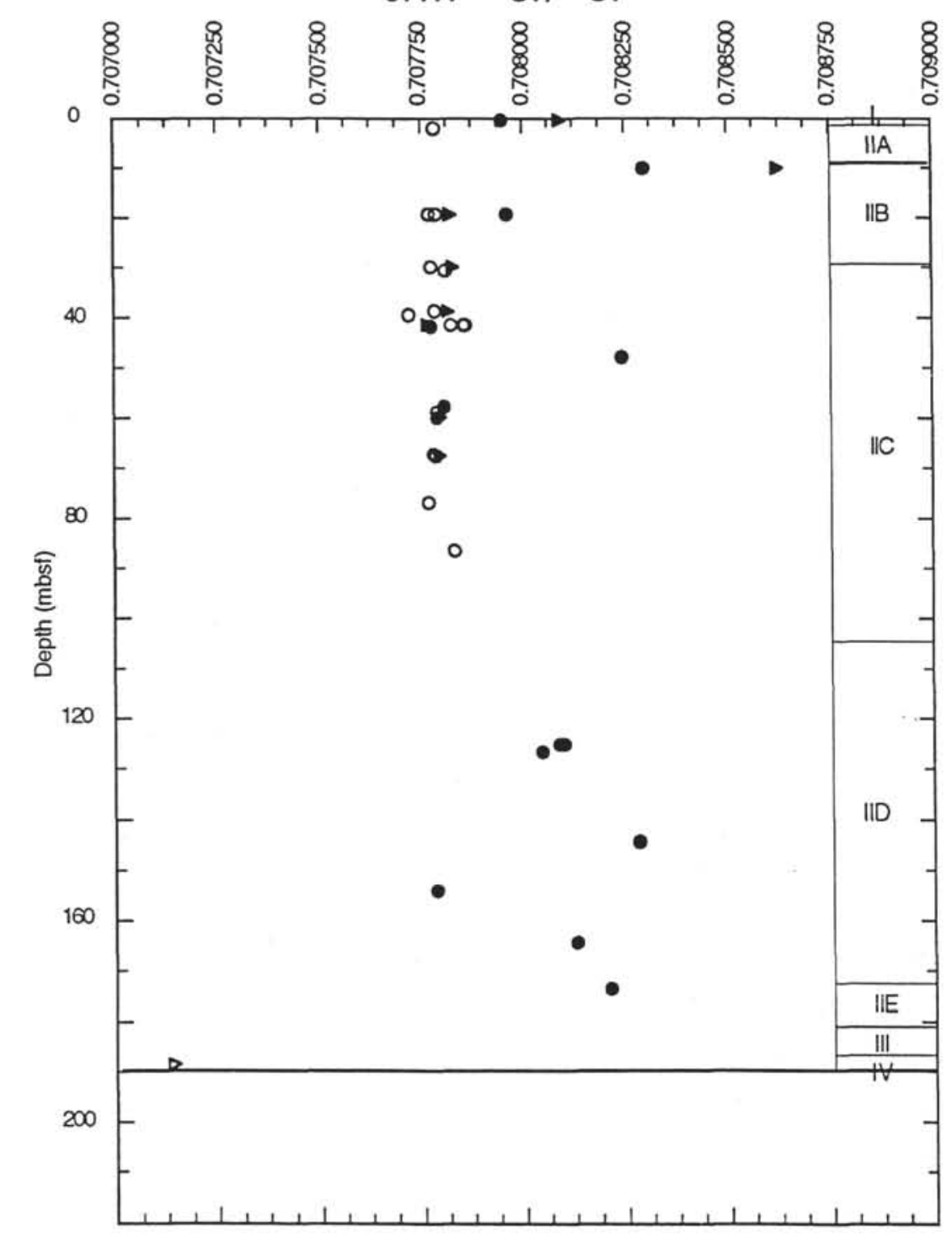

Figure 15 (continued).

mbsf (Figs. 6-7). Wyatt et al. (this volume) noted lower ${ }^{18} \mathrm{O}$ in Hole 874 at 40 mbsf, as well as near the surface (Figs. 13-14). Shallowmarine cement (RC and RC-FIC) occurs in dissolution pores at several levels, for example in Hole 877A at 48.75, 42.35, 10.16, 9.89, and $2.5 \mathrm{mbsf}$ (Fig. 11). The implication is that the dissolution occurred before submergence of the platform, probably intermittently with deposition, when meteoric water was the only undersaturated water available. Wilson et al. (this volume) suggest, however, that even near-surface seawater may have been undersaturated with respect to aragonite in the Late Cretaceous "calcite sea" (Sandberg, 1983). The clasts embedded in the MIMSP (the middle unit of the outer perimeter ridge) appear to have been eroded from Subunit IIB of the inner perimeter ridge, which is, conveniently, somewhat older. Gastropod molds and small vugs were etched into the limestone before erosion, or at least before redeposition in relatively shallow water, no more than 150 mbsf (top of Subunit IIB in Hole 877A, the eroding source, to top of Subunit IIB in Hole $875 \mathrm{C}$ ). This requires leaching near the sea level; it probably reflects exposure to meteoric water. Subunit IIB was interpreted in part as peritidal and penecon- temporaneously lithified (Camoin et al., this volume). Some appreciable period of exposure may have been involved.

The uniformity of the ${ }^{87} \mathrm{Sr} /{ }^{86} \mathrm{Sr}$ ratios in Hole $877 \mathrm{~A}$ at values consistent with a Late Cretaceous age $(0.70775-0.70780$; Fig. 15B) led Wilson et al. (this volume) to conjecture that "carbonate platform sedimentation was not interrupted by hiatal surfaces associated with periods of platform exposure longer than $\sim 1 \mathrm{Ma} . .$. The more radiogenic variants (Fig. 15B) were attributed to later cement growth from seawater. Terrestrial runoff as a source of more radiogenic Sr would not be a possibility, even in the early stages of atoll development when the weathered volcanic core may have been exposed, because young oceanic volcanics would have a mantle signature, lower ${ }^{87} \mathrm{Sr} /$ ${ }^{86} \mathrm{Sr}$. At Site $874,{ }^{87} \mathrm{Sr} /{ }^{86} \mathrm{Sr}$ values are somewhat higher, ranging from about 0.70780 to 0.70786 in the upper $140 \mathrm{~m}$ (Wyatt et al., this volume). No alteration of primary strontium values is indicated. The highest value, 0.707869 , near the top indicates a late Maastrichtian age, about $67 \mathrm{Ma}$. An offset to lower ratios of about 0.707730 at 140 mbsf (the top of Subunit IIF) is taken as the Campanian/Maastrichtian boundary (Wyatt et al., this volume). This is precisely where the 
SITE 874 , ALL DATA

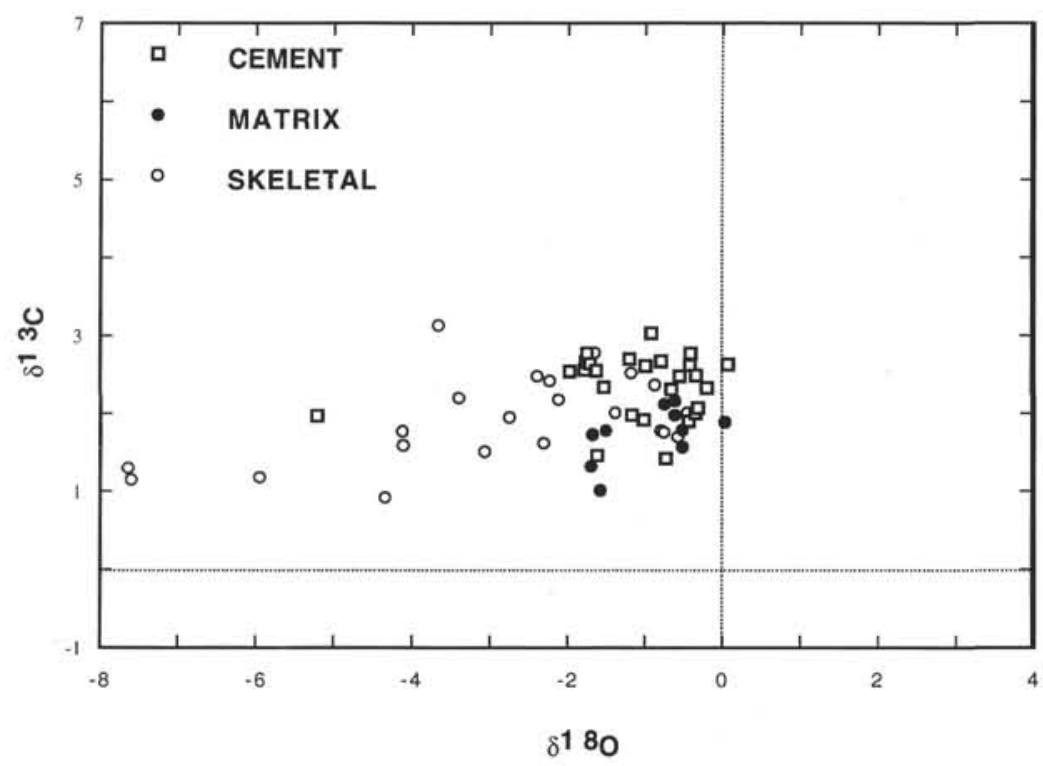

Figure 16. Cross plot of stable isotopic compositions, Site 874 .

SITE 877 , ALL DATA

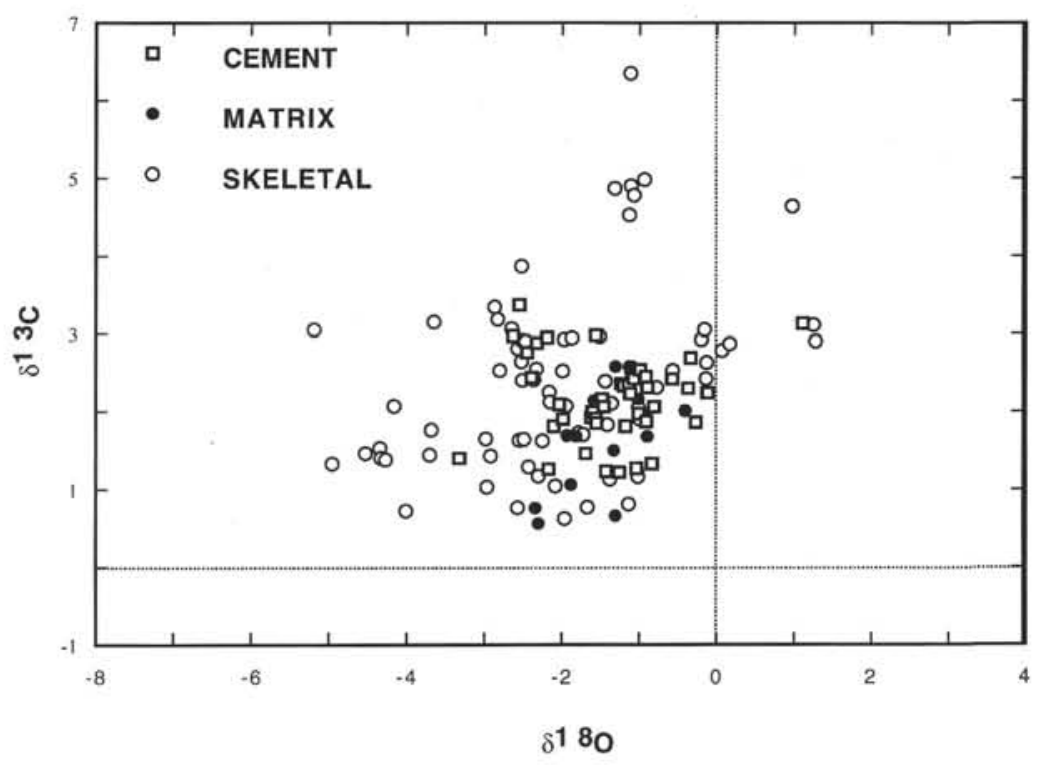

Figure 17. Cross plot of stable isotopic compositions, Site 877.

ments from all sites fall within the range of $-3.32 \%$ to $-0.12 \%$ for $\delta^{18}$ $\mathrm{O}$ with an average of $-1.19 \%$ (Table 2 ). The $\delta^{13} \mathrm{C}$ values range from $+1.22 \%$ to $+2.98 \%$ with an average of $+2.07 \%$. These values are close to expectation for cements precipitated from Late Cretaceous seawater and, indeed, from modern shallow-marine water (James and Choquette, 1983; Lohmann, 1988).

Numerous studies of radiaxial cements involving many facets of their geologic occurrence, chemistry, and comparison with presumed modern analogs have led to the conventional wisdom that such cements are precipitates of shallow-marine waters (cf. Kendall and Tucker, 1973; James and Choquette, 1983; but see Saller, 1986). Normally they were metastable phases (but see Kendall, 1985), magnesian calcite or aragonite, that were neomorphosed to calcite with remarkable retention of fabric and chemical characteristics. The radiaxial cements at Wodejebato fit this interpretation to the extent that they have been analyzed. Radiaxial cement is typically the first cement, is nearly confined to primary porosity, is overlain by or inter- 
RUDISTS, ALL SITES

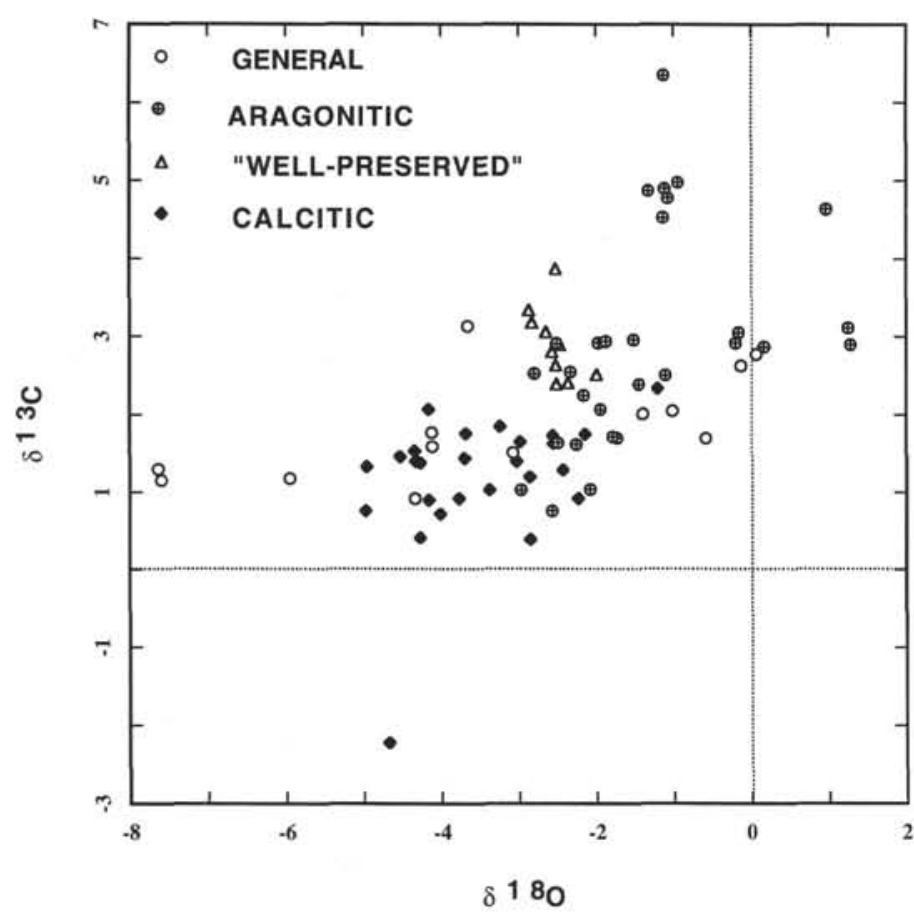

Figure 18. Stable isotopic composition of rudist shells with different types of preservation, Sites 873,874 , and 877 . layered with marine internal sediment in several cases, and the isotopes are consistent with precipitation from marine waters. Magnesium contents in Hole $877 \mathrm{~A}$ range from $3.44 \%$ to $6.07 \%$ (corresponding to about $1-2 \mathrm{~mol} \% \mathrm{MgCO}_{3}$ ) and strontium values range from $0.13 \%$ to $0.38 \%$ (Opdyke et al., this volume, tables $2-3$ ). These values suggest a magnesian-calcite precursor.

We regard the radiaxial fibrous cement (RC-FIC) as a variant of radiaxial cement, distinguished by its fibrous crystal habit (axial ratio $\gg 6: 1 ;$ Folk, 1965). It was distinguished initially to see whether other essential distinctions existed and was retained primarily to emphasize that many cements referred to in print as radiaxial fibrous are actually bladed or even equant aggregates of elongate subcrystals. In Wodejebato cores, their occurrence, chemistry (Table 2), and other essential attributes are indistinguishable from RC. Fascicular optic calcites (Kendall, 1977), in which the optic axes of subcrystals diverge rather than converge as in RC, were mentioned separately by Camoin et al. (this volume), presumably for the same reasons, with the same negative result. Fascicular optic calcite commonly occurs in the same mosaics with radiaxial calcite, especially where the pore wall is convex into the pore. All of these variants, radiaxial, radiaxial fibrous, and fascicular optic, are interpreted as early, shallow-marine cements in their Wodejebato occurrences.

Pyramidal, limpid calcite with uniform extinction (PLUC) is by far the most widespread cement in Wodejebato cores, although it does not form the voluminous crusts that are typical of RC. The PLUC also does not have the voluminous literature that RC enjoys; its global distribution is much less. Its defining characteristics are pyramidal habit, clarity, and uniform extinction (Table 1). The crystal habit is typically elongated (bladed), simple, and acute scalenohedral. Very small crystals commonly have blunt or rounded terminations. These terminations are attributed to slight dissolution of the originally sharp crystal forms. The pristine, limpid appearance and uniform extinction of PLUC suggest that it has not undergone neomorphism or any diagenetic trauma other than this slight dissolution.. The size range of individual crystals is extreme, from about $5 \mu \mathrm{m}$ to several millimeters (Folk, 1965; classes 2 through 6). In some pores, PLUC is a few tiny isolated crystals; in others, it may fill the pore, even as a single crystal. These extremes may occur in the same sample. In many samples, especially from the outer perimeter ridge, PLUC is the only cement. The PLUC occurs in all types of pores, but is somewhat more common in primary than in secondary pores in most samples. The PLUC also postdates the RC where they occur together, with a few possible exceptions. The contact between the RC and the overlying PLUC is typically sharp (Figs. 1 and 4), but in many examples the contact appears to be gradational, without intervening sedimentation, bioerosion, or dissolution.

The distribution of PLUC indicates that it did not compete with $\mathrm{RC}$ in the shallow marine setting. The PLUC occurs in dissolution pores, but is more abundant and coarser in primary pores. The rounding of tiny PLUC crystals is attributed to dissolution. These observations and inferences suggest the PLUC precipitation and dissolution overlapped or alternated in time.

Stable isotopic compositions of PLUC overlap those of RC (Fig. 20 ). Oxygen values range from $-7.80 \%$ to $+2.87 \%$, but $95 \%$ of the values fall between $-2.49 \%$ and $+1.11 \%$. The mean is $-0.74 \% \pm$ $0.82 \%$ (Table 2). The range of $\delta^{13} \mathrm{C}$ is $+1.18 \%$ to $+3.13 \%$, with an average of $2.19 \% \pm 0.48 \%$. Cements identified as PLUC with very low ${ }^{18} \mathrm{O}$ (top of platform carbonates at Site 873; Figs. 8A and 20) are probably a case of mistaken cement identity. No meteoric cements were recognized, but pore-filling PLUC might be confused with equant, blocky spar, typical of meteoric phreatic cement. The distinctive acute pyramidal habit of PLUC could not be discerned in the compromise boundaries of filled pores.

Strontium-isotopic composition of a few PLUC samples and most of the "matrix" samples (largely PLUC; Fig. 15B) from the base of Hole $877 \mathrm{~A}$ indicates precipitation during the Tertiary, well after the drowning of Wodejebato (Wilson et al., this volume). This indication of a relatively late age for PLUC cements can be reconciled with its distribution and stable-isotopic composition. It formed later than the shallow-water cements. Stable-isotopic composition appears marine. The PLUC overlapped or alternated with episodes of dissolution. Furthermore, the PLUC knows no stratigraphic bounds: it occurs throughout the platform carbonates and does not appear to be concentrated at any particular horizon. Similar cement is reported from for- 


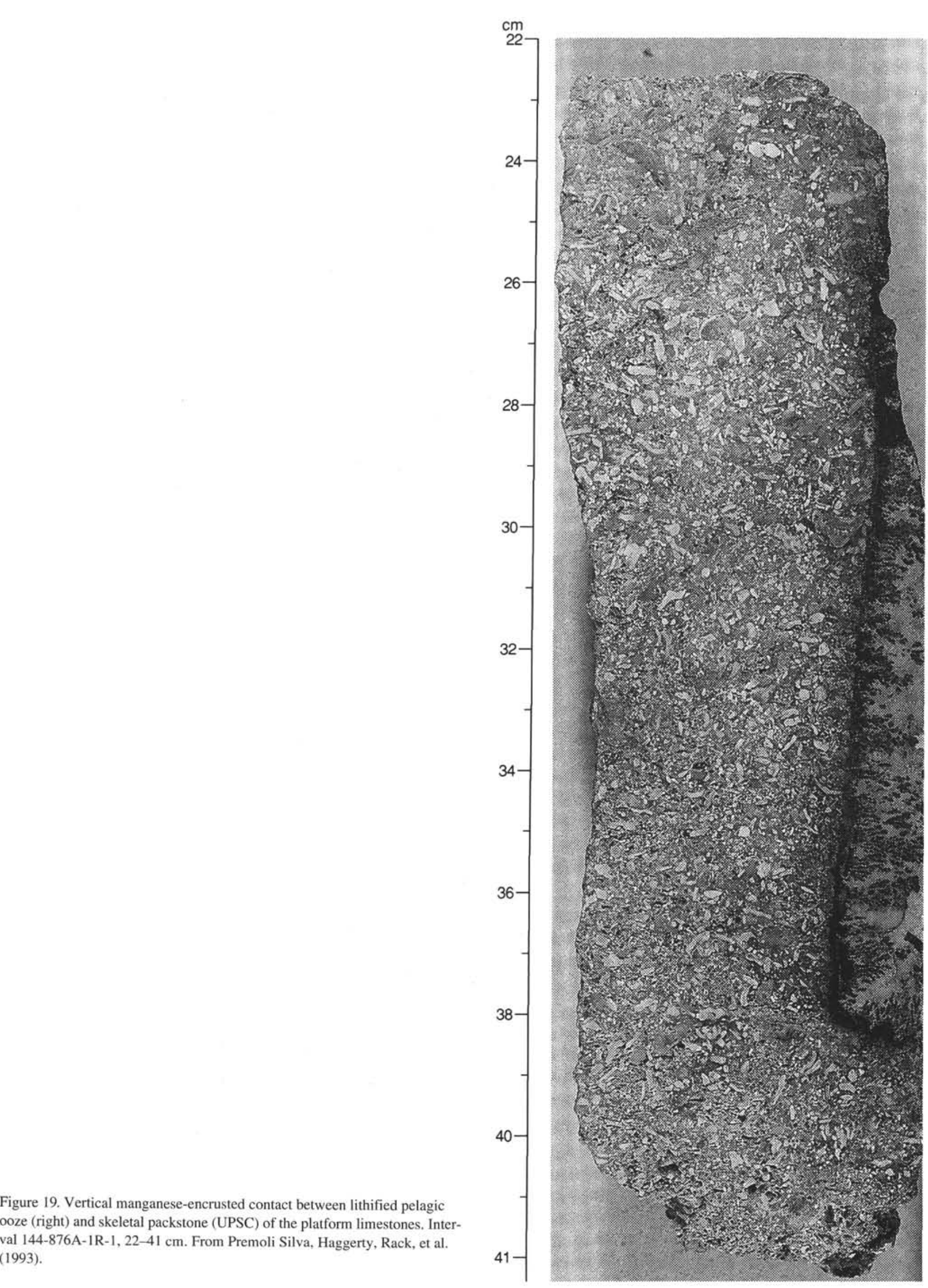


CEMENTS, ALL DATA

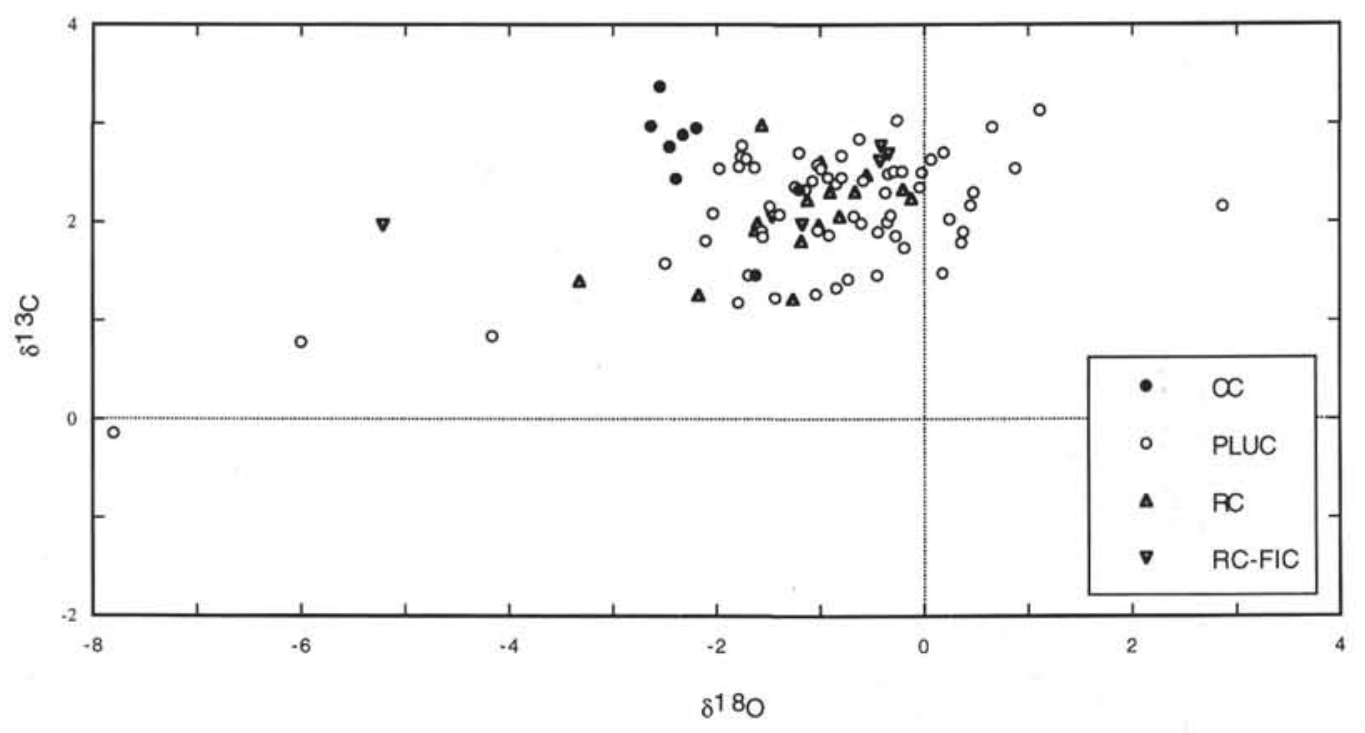

Figure 20. Stable isotopic compositions of cements, Sites 873,874 , and 877 . See Table 1 for cement characterization.

aminiferal chambers and cavities in Eocene oozes from the pelagic cap of Wodejebato (Appendix). These attributes indicate that PLUC precipitated from deeper marine waters that bathed Wodejebato after it was submerged below the photic zone and the deposition of platform carbonates ceased. The waters would be cooler and perhaps undersaturated with respect to aragonite and magnesian calcite, thus facilitating precipitation of calcite in preexisting pore space.

Relative water temperatures of PLUC precipitation can be calculated if either aragonitic rudists or columnar cement (CC) is accepted as representing equilibrium precipitation from Cretaceous near-surface seawater (Tables 2-3). Using the oxygen fractionation with temperature relationship of Epstein et al. (1953) as modified in Anderson and Arthur (1983), the temperature difference between two carbonate phases can be approximated as: $\Delta \mathrm{T}^{\circ} \mathrm{c}=4.14\left(\delta \mathrm{c}_{2}-\delta \mathrm{c}_{1}\right)-0.13\left(\delta \mathrm{c}_{2} 2\right.$ $\left.-\delta c_{1} 2\right)+0.26 \delta w\left(\delta c_{2}-\delta c_{1}\right)$ where $\delta c_{2}$ and $\delta c_{1}$ are $\delta^{18} O$ of the carbonate phases relative to PDB and $\delta w$ is the $\delta^{18} \mathrm{O}$ of Maastrichtian seawater relative to SMOW. $\delta$ w can be approximated by using $\delta^{18} \mathrm{O}$ of $c_{1}$ (aragonitic rudists or $\mathrm{CC}$, in this case) and reasonable estimates of surface seawater temperatures. Its influence on the result is small in any case. A range of $-2.0 \%$ to $+0.88 \%$ was used in the calculations; the latter value corresponds to a temperature of $30^{\circ} \mathrm{C}$ for precipitation of $\mathrm{CC}\left(\delta^{18} \mathrm{O}=-2.17 \%\right)$, probably an upper limit. The calculated temperature differences are from $-6.80^{\circ} \mathrm{C}$ for PLUC relative to $\mathrm{CC}$ with $\delta \mathrm{w}=+0.88 \%$ to $-5.70^{\circ} \mathrm{C}$ with $\delta \mathrm{w}=-2 \%$. Relative to aragonitic rudists the differences would be -2.78 and $-2.33^{\circ}$, respectively. A good approximation is probably $-6.5^{\circ}$, relative to $\mathrm{CC}$ with $\delta \mathrm{w}=0 \%$. The differences may be less than would be anticipated across an oceanic thermocline, but do indicate cooler temperatures for precipitation of PLUC.

Syntaxial overgrowths (SOC) and PLUC occur in the same samples toward the base of the platform carbonates. The age relations are rarely clear because both are patchy in distribution and SOC does not form crusts. In a few examples, a fine crust of PLUC crystals could be identified beneath an overgrowth on the fragment that served as the syntaxial nucleus of the overgrowth cement. SOC cements were not studied extensively. Their distribution and crystal characteristics suggest they formed in the same environment as PLUC. Syntaxial overgrowth favored the development of large crystals, probably by the merger of many nuclear crystals with common crystallographic orientation determined by the substratum-echinoderms, benthic foraminifers, or mollusks.

The columnar magnesian calcites (CC; Table 1) were recognized with certainty only from Section 144-877A-5R-3 (Fig. 11). The convergent optic axes and sweeping extinction of $\mathrm{CC}$ cement, even in the absence of inclusions, would once have been considered prima-facie evidence for diagenetic alteration of a metastable precursor (cf. Kendall and Tucker, 1973). However, A.C. Kendall later recanted, probably over-recanted, and demonstrated that radiaxial calcite could occur as a primary precipitate (Kendall, 1985). His example probably originated as magnesian calcite in marine waters. Oxygen isotopic compositions of CC lie between $-2.32 \%$ and $-1.62 \%$, with a mean of $-2.17 \%$ (Tables $2-3$ ), indicating precipitation in shallow, warm seawater. However, a magnesium carbonate content of $7 \mathrm{~mol} \%$, if original, suggests cold water (Mackenzie et al., 1983), if the magnesium/ calcium ratio of the Late Cretaceous seawater was not radically different from modern values.

\section{Neomorphism}

The conditions and timing of neomorphism can rarely be fixed petrographically, because neomorphic crystals generally do not crosscut other diagenetic phases and because neomorphic fabrics are typically more influenced by the original grain than by the diagenetic environments. The $\delta^{18} \mathrm{O}$ values of many fossil and matrix samples from Wodejebato are rather low, $-5 \%$ to $-8 \%$ (Figs. 8,13 , and 18). These are more negative than almost any cement sample. These particles, at least, appear to have been altered in meteoric water. Camoin et al. (this volume) were able to relate the degree of depletion to specific fabrics. Rudists with inclusion-free calcite, that thus retained few vestiges of the architecture of the aragonite skeleton, were those with the lowest oxygen isotopes (average $\delta^{18} \mathrm{O}$ of $-3.51 \%$; Table 3 ).

\section{Dissolution}

The record of dissolution is a void. Thus dissolution must be interpreted and timed by geologic evidence and petrographic evidence. The fluids responsible are largely a subject of inference, beyond the 
given that they must have been undersaturated with the dissolved phase, if its mineralogy can be determined, and that they must have been available in sufficient volume.

The platform limestone of Wodejebato is $40 \%$ voids in some intervals; perhaps more where recovery was nil. Fluids responsible for dissolution in Wodejebato could have been meteoric water or undersaturated seawater. Submergence of the guyot should demarcate these possibilities, suggesting that the distinction could be readily made. As usual, conclusions will be equivocal. Some dissolution occurred before submergence as is indicated by molds in reworked pebbles and by shallow-marine cements (RC) and sediments within dissolution pores, as outlined above. The question is one of how much and how soon.

Subaerial exposure is required to introduce meteoric water into the platform carbonates. Because dissolution porosity is prevalent throughout and is most extensive in the limestones of the deeper outer perimeter ridge, extensive subaerial exposure would be required with the meteoric alternative. The case for subaerial exposure was reviewed above. It is strong enough to consider meteoric leaching as a viable possibility. Proving subaerial exposure would not, of course, prove its role in dissolution.

Several lines of circumstantial evidence support considerable dissolution in deeper marine water: the occurrence of the late phase of cement (PLUC) in dissolution pores; its greater abundance and coarser crystallinity in primary pores; and the rounding of small PLUC crystals are taken to indicate that precipitation of PLUC coincided with or alternated with leaching. The PLUC was interpreted as a precipitate of deeper marine waters. Dissolution concurrent with or alternating with PLUC would also have occurred in these waters. The PLUC was precipitated as stable calcite because the deeper waters were undersaturated with respect to aragonite and magnesian calcite. The same waters probably dissolved much of the aragonite and magnesian calcite that originally formed the platform-carbonate cap of Wodejebato Atoll, as it then was.

Simultaneous dissolution of a metastable carbonate phase and precipitation of a more stable, that is, less soluble phase from the same water, even within the same pore, is a widely recognized phenomenon in meteoric waters (cf. Pingatore, 1976). This process is feasible in marine waters between the aragonite and the deeper calcite saturation levels (Saller and Koepnick, 1990). The relevance here is that much less circulation of seawater would be required if the two processes proceeded simultaneously in the same water mass. In the extreme case, no circulation would be necessary at all.

Time may also favor dissolution in deeper marine waters. If Wodejebato atoll was submerged in mid-Maastrichtian ( 70.5 m.y.; Wilson et al., this volume) the time available for subaerial dissolution after deposition of the platform carbonates would have been very short (see calculations of dissolution rates in Enos et al., this volume). Dissolution in deeper marine waters could have begun as soon as Wodejebato sank below the level of aragonite saturation, 300 to 400 $\mathrm{m}$ in the modern Pacific Ocean. Dissolution likely continues to the present day, perhaps hand-in-hand with PLUC precipitation.

\section{CONCLUSIONS}

Cementation, neomorphism, and dissolution were important factors in forming the platform limestones of Wodejebato Guyot.

Radiaxial cement (RC) formed in shallow marine waters, generally during deposition. In a few samples, $\mathrm{RC}$ also occludes secondary pores (MO), indicating precipitation after dissolution that probably occurred in meteoric waters. The radiaxial cement is volumetrically important only in the upper $70 \mathrm{~m}$ of the inner perimeter ridge.

Prismatic limpid cement (PLUC) formed in deeper, cooler marine waters, after submergence of Wodejebato. It occurs throughout the platform limestones, in both primary and secondary porosity.
Primary magnesian calcite cement (CC) and aragonite layers of rudist shells are preserved in a small "reef" interval from the inner perimeter ridge (Hole 877A).

Subaerial exposure at the end of platform limestone development may have produced a microkarst surface on the atoll before drowning.

Earlier, syndepositional episodes of exposure are indicated by petrographic evidence, such as rhizoliths and alveolar textures, and by low $\delta^{18} \mathrm{O}$ values at several levels. No unequivocal exposure surface was recovered in core, although the vertical contact of platform limestones with pelagic limestones at the top of the outer perimeter ridge (Hole $876 \mathrm{~A}$ ) is probably such.

Low $\delta^{18} \mathrm{O}$ and $\delta^{13} \mathrm{C}$ contents in fossils and matrix indicate neomorphism in meteoric waters.

At least minor dissolution occurred before submergence of Wodejebato. Dissolution in deeper marine waters is also indicated for much of the small-scale secondary porosity.

\section{REFERENCES}

Al-Aasm, I.S., and Veizer, J., 1986. Diagenetic stabilization of aragonite and low-Mg Calcite, II. Stable isotopes in rudists. J. Sediment. Petrol., 56:763-770.

Allan, J.R., and Matthews, R.K., 1982. Isotopic signatures associated with early meteoric diagenesis. Sedimentology, 29:797-817.

Anderson, T.F., and Arthur, M.A., 1983. Stable isotopes of oxygen and carbon and their application to sedimentologic and paleoenvironmental problems. SEPM Short Course, 10:1-151.

Bathurst, R.G.C., 1959. The cavernous structure of some Mississippian Stromatactic reefs in Lancashire, England. J. Geol., 67:506-521.

1975. Carbonate Sediments and Their Diagenesis (2nd ed.): Amsterdam (Elsevier).

Choquette, P.W., and Pray, L.C., 1970. Geologic nomenclature and classification of porosity in sedimentary carbonates. AAPG Bull., 54:207-250.

Epstein, S., Buchsbaum, R., Lowenstam, H.A., and Urey, H.C., 1953. Revised carbonate-water isotopic scale. Geol. Soc. Am. Bull., 64:13151325.

Esteban, M., and Klappa, C.F., 1983. Subaerial exposure environment. In Scholle, P.A., Bebout, D.G., and Moore, C.H. (Eds.), Carbonate Depositional Environments. AAPG Mem., 33:1-54.

Folk, R.L., 1965. Some aspects of recrystallization in ancient limestones. In Pray, L.C., and Murray, R.C. (Eds.), Dolomitization and Limestone Diagenesis. Spec. Publ.-Soc. Econ. Paleontol. Mineral., 13:13-48.

Freeman-Lynde, R.P., Whitley, K.F., and Lohmann, K.C, 1986. Deepmarine origin of equant spar cements in Bahama Escarpment limestones. J. Sediment. Petrol., 56:799-811.

Given, R.K., and Lohmann, K.C, 1985. Derivation of the original isotopic composition of Permian marine cements. J. Sediment. Petrol., 55:430439.

Goldstein, R.H., 1991. Stable isotope signatures associated with paleosols, Pennsylvanian Holder Formation, New Mexico. Sedimentology, 38:777803.

James, N.P., and Choquette, P.W., 1983. Diagenesis 6: Limestones: the seafloor diagenetic environment. Geosci. Can., 10:162-179.

Kendall, A.C., 1977. Fascicular-optic calcite: a replacement of bundled acicular carbonate cements. J. Sediment. Petrol., 47:1056-1062.

, 1985. Radiaxial fibrous calcite: a reappraisal. In Schneidermann, N., and Harris, P.H. (Eds.), Carbonate Cements. Spec. Publ.-Soc. Econ. Paleontol. Mineral., 36:59-77.

Kendall, A.C., and Tucker, M.E., 1973. Radiaxial fibrous calcite: a replacement after acicular aragonite. Sedimentology, 20:365-390.

Lohmann, K.C, 1988. Geochemical patterns of meteoric diagenetic systems and their application to studies of paleokarst. In James, N.P., and Choquette, P.W. (Eds.), Paleokarst: New York (Springer-Verlag), 5880.

Lohmann, K.C, and Meyers, W.J., 1977. Microdolomite inclusions in cloudy prismatic calcites: a proposed criterion for high-magnesium calcites. $J$. Sediment. Petrol., 47:1078-1088.

Lohmann, K.C, and Walker, J.C.G., 1989. The $\delta^{18} \mathrm{O}$ record of Phanerozoic abiotic marine calcite cements. Geophys. Res. Lett., 16:319-322.

Mackenzie, R.T., Bischoff, W.D., Bishop, F.C., Loijens, M., Schoonmaker, J., and Wollast, R., 1983. Magnesian calcites: low-temperature occur- 
rence, solubility, and solid solution behavior. In Reeder, R.J. (Ed.), Carbonates: Mineralogy and Chemistry. Mineral Soc. Am., Rev. Mineral., 11:97-144.

Moldovanyi, E.P., and Lohmann, K.C, 1984. Isotopic and petrographic record of phreatic diagenesis: Lower Cretaceous Sligo and Cupido Formations. J. Sediment. Petrol., 54:972-985.

Pingitore, N.E., Jr., 1976. Vadose and phreatic diagenesis: processes, products, and their recognition in corals. J. Sediment. Petrol., 46:985-1006.

Premoli Silva, I., Haggerty, J., Rack, F., et al., 1993. Proc. ODP, Init. Repts., 144: College Station, TX (Ocean Drilling Program).

Saller, A.H., 1986. Radiaxial calcite in lower Miocene strata, subsurface Enewetak Atoll. J. Sediment. Petrol., 56:743-762.
Saller, A.H., and Koepnick, R.B., 1990. Eocene to early Miocene growth of Enewetak Atoll: insight from strontium isotope data. Geol. Soc. Am. Bull., 102:381-390.

Sandberg, P.A., 1983. An oscillating trend in Phanerozoic non-skeletal carbonate mineralogy. Nature, 305:19-22.

Schlager, W., and James, N.P., 1978. Low-magnesian calcite limestones forming at the deep-sea floor, Tongue of the Ocean, Bahamas. Sedimentology, 25:675-702.

Date of initial receipt: 1 August 1994

Date of acceptance: 13 January 1995

Ms 144SR-062 
APPENDIX

Isotopic Data, Wodejebato Guyot

\begin{tabular}{|c|c|c|c|c|c|c|c|}
\hline Hole & $\begin{array}{l}\text { Core, section, } \\
\text { interval }(\mathrm{cm})\end{array}$ & $\begin{array}{l}\text { Depth } \\
\text { (mbsf) }\end{array}$ & $\delta^{13} \mathrm{C}$ & $\delta^{18} \mathrm{O}$ & ${ }^{87} \mathrm{Sr} /{ }^{86} \mathrm{Sr}$ & Component & Source \\
\hline $873 \mathrm{~A}$ & IR-1, 0-3 & 54.30 & 0.90 & -4.16 & & Rudist, radiolite & Lincoln \\
\hline $873 \mathrm{~A}$ & IR-1,0-3 & 54.30 & 0.58 & -3.49 & & Red alga & Lincoln \\
\hline $873 \mathrm{~A}$ & $1 \mathrm{R}-1,0-3$ & 54.30 & 2.16 & 2.87 & & Cement, PLUC & Lincoln \\
\hline $873 B$ & $8 \mathrm{~N}-1,4-7$ & 58.04 & 0.76 & -4.97 & & Rudist, calcite & Lincoln \\
\hline $873 B$ & $8 \mathrm{~N}-1,4-7$ & 58.04 & 0.80 & -3.63 & & Red alga & Lincoln \\
\hline $873 B$ & $8 \mathrm{~N}-1,4-7$ & 58.04 & -0.14 & -7.80 & & Cement, PLUC & Lincoln \\
\hline $873 B$ & $8 \mathrm{~N}-2, \quad 67-70$ & 60.04 & 1.26 & -4.45 & & Foraminifer, benthic & Lincoln \\
\hline $873 B$ & $9 \mathrm{~N}-1,61-65$ & 63.11 & -1.71 & -5.17 & & Foraminifer, benthic & Lincoln \\
\hline $873 B$ & $9 \mathrm{~N}-1,61-65$ & 63.11 & -1.78 & -5.26 & & Matrix & Lincoln \\
\hline $873 B$ & $9 \mathrm{~N}-1,61-65$ & 63.11 & 1.29 & -2.24 & & Matrix & Lincoln \\
\hline $873 B$ & $9 \mathrm{~N}-2,10-15$ & 63.95 & -2.22 & -4.67 & & Rudist, calcite & Lincoln \\
\hline $873 \mathrm{~B}$ & $9 \mathrm{~N}-2,10-15$ & 63.95 & -4.28 & -4.81 & & Red alga & Lincoln \\
\hline $873 \mathrm{~B}$ & $9 \mathrm{~N}-2,10-15$ & 63.95 & -2.37 & -4.54 & & Cement & Lincoln \\
\hline $873 B$ & $10 \mathrm{~N}-1,67-69$ & 67.67 & -1.38 & -5.39 & & Foraminifer, benthic & Lincoln \\
\hline $873 B$ & $10 \mathrm{~N}-1,67-69$ & 67.67 & -0.38 & -4.04 & & Red alga & Lincoln \\
\hline 873B & $10 \mathrm{~N}-1,67-69$ & 67.67 & 1.46 & -3.06 & & Micrite envelope & Lincoln \\
\hline $873 B$ & $10 \mathrm{~N}-1,67-69$ & 67.67 & 0.78 & -6.00 & & Cement, PLUC & Lincoln \\
\hline $873 \mathrm{~B}$ & $10 \mathrm{~N}-1,142-146$ & 68.42 & 1.85 & -3.24 & & Rudist, calcite & Lincoln \\
\hline $873 \mathrm{~A}$ & $4 \mathrm{R}-1,0-3$ & 78.70 & 1.75 & -2.14 & & Rudist, calcite & Lincoln \\
\hline $873 \mathrm{~A}$ & $4 \mathrm{R}-1,0-3$ & 78.70 & 0.63 & -0.91 & & Red alga & Lincoln \\
\hline $873 \mathrm{~A}$ & $4 \mathrm{R}-1,0-3$ & 78.70 & 2.30 & 0.48 & & Cement, PLUC & Lincoln \\
\hline $873 \mathrm{~A}$ & $5 \mathrm{R}-1,26-32$ & 88.56 & -0.83 & -0.62 & & Matrix & Lincoln \\
\hline $873 \mathrm{~A}$ & $5 \mathrm{R}-1,60-63$ & 88.90 & 1.14 & -0.78 & & Matrix & Lincoln \\
\hline $873 \mathrm{~A}$ & $5 \mathrm{R}-1,74-77$ & 89.04 & 1.48 & 0.18 & & Cement, PLUC & Lincoln \\
\hline $873 \mathrm{~A}$ & $5 \mathrm{R}-1,87-91$ & 89.17 & 1.73 & -2.56 & & Rudist, calcite & Lincoln \\
\hline $873 \mathrm{~A}$ & $5 \mathrm{R}-1,87-91$ & 89.17 & 2.88 & -0.53 & & Foraminifer, benthic & Lincoln \\
\hline $873 \mathrm{~A}$ & $5 R-1,87-91$ & 89.17 & 2.35 & -0.04 & & Cement, PLUC & Lincoln \\
\hline $873 \mathrm{~A}$ & $5 R-1,113-117$ & 89.43 & 2.96 & 0.66 & & Cement, PLUC & Lincoln \\
\hline $873 \mathrm{~A}$ & $6 \mathrm{R}-1,28-33$ & 98.28 & 2.90 & -0.51 & & Foraminifer, benthic & Lincoln \\
\hline $873 \mathrm{~A}$ & $6 \mathrm{R}-1,63-67$ & 98.63 & 1.20 & -2.86 & & Rudist, calcite & Lincoln \\
\hline $873 \mathrm{~A}$ & $6 \mathrm{R}-1,63-67$ & 98.63 & 1.98 & -0.01 & & Matrix & Lincoln \\
\hline $873 \mathrm{~A}$ & $6 \mathrm{R}-1,63-67$ & 98.63 & 2.03 & 0.25 & & Cement, PLUC & Lincoln \\
\hline $873 \mathrm{~A}$ & $6 \mathrm{R}-1.89-92$ & 98.89 & 0.39 & -2.85 & & Rudist, calcite & Lincoln \\
\hline $873 \mathrm{~A}$ & $6 \mathrm{R}-1,89-92$ & 98.89 & 1.79 & 0.36 & & Cement, PLUC & Lincoln \\
\hline $873 \mathrm{~A}$ & $6 \mathrm{R}-1,122-125$ & 99.22 & 1.90 & 0.38 & & Cement, PLUC & Lincoln \\
\hline $873 \mathrm{~A}$ & $6 \mathrm{R}-1,122-125$ & 99.22 & 2.15 & -0.20 & & Matrix & Lincoln \\
\hline $873 \mathrm{~A}$ & $7 \mathrm{R}-1,0-4$ & 107.60 & 2.11 & -0.16 & & Matrix & Lincoln \\
\hline $873 \mathrm{~A}$ & $7 \mathrm{R}-1,0-4$ & 107.60 & 3.03 & -0.26 & & Cement, PLUC & Lincoln \\
\hline $873 \mathrm{~A}$ & $7 \mathrm{R}-1,46-51$ & 108.06 & 2.50 & -0.02 & & Cement, PLUC & Lincoln \\
\hline $873 \mathrm{~A}$ & $7 \mathrm{R}-1,46-51$ & 108.06 & 2.12 & -0.89 & & Matrix & Lincoln \\
\hline $873 \mathrm{~A}$ & $7 \mathrm{R}-2, \quad 14-17$ & 109.24 & 2.34 & -1.20 & & Rudist, calcite & Lincoln \\
\hline $873 \mathrm{~A}$ & $7 \mathrm{R}-2,14-17$ & 109.24 & 2.54 & 0.88 & & Cement, PLUC & Lincoln \\
\hline $873 \mathrm{~A}$ & $7 R-2,14-17$ & 109.24 & 2.79 & -0.54 & & Matrix & Lincoln \\
\hline $873 \mathrm{~A}$ & $7 R-2,14-17$ & 109.24 & 2.77 & -0.46 & & Matrix & Lincoln \\
\hline $873 \mathrm{~A}$ & $8 \mathrm{R}-1, \quad 132-137$ & 118.62 & 0.31 & -1.68 & & Matrix & Lincoln \\
\hline $873 \mathrm{~A}$ & $8 \mathrm{R}-1,132-137$ & 118.62 & 1.74 & -0.19 & & Cement, PLUC & Lincoln \\
\hline $873 \mathrm{~A}$ & $8 R-1,89-95$ & 118.62 & 1.03 & -3.38 & & Rudist, calcite & Lincoln \\
\hline $873 \mathrm{~A}$ & $8 \mathrm{R}-1,89-95$ & 118.62 & 2.51 & -0.29 & & Cement, PLUC & Lincoln \\
\hline $873 \mathrm{~A}$ & $8 \mathrm{R}-1,14-19$ & 118.62 & 2.70 & 0.19 & & Cement, PLUC & Lincoln \\
\hline $873 \mathrm{~A}$ & $8 \mathrm{R}-1,14-19$ & 118.62 & 0.11 & -2.07 & & Foraminifer, benthic & Lincoln \\
\hline $873 \mathrm{~A}$ & $9 \mathrm{R}-1,9-11$ & 126.99 & 0.67 & -1.23 & & Foraminifer, benthic & Lincoln \\
\hline $873 \mathrm{~A}$ & $9 \mathrm{R}-1,9-11$ & 126.99 & 2.28 & -0.24 & & Alga, Terquemella & Lincoln \\
\hline $873 \mathrm{~A}$ & $9 \mathrm{R}-1,70-75$ & 127.60 & 2.17 & 0.45 & & Cement, PLUC & Lincoln \\
\hline $873 \mathrm{~A}$ & $9 \mathrm{R}-1,135-142$ & 128.25 & 2.08 & -1.39 & & Cement, PLUC & Lincoln \\
\hline $873 \mathrm{~A}$ & $9 \mathrm{R}-2,23-28$ & 128.63 & -0.11 & -2.65 & & Matrix & Lincoln \\
\hline $873 \mathrm{~A}$ & $9 R-2,23-28$ & 128.63 & 2.45 & -0.79 & & Cement, PLUC & Lincoln \\
\hline $873 \mathrm{~A}$ & $9 \mathrm{R}-2,87-92$ & 129.27 & 0.92 & -3.77 & & Rudist, calcite & Lincoln \\
\hline $873 \mathrm{~A}$ & $9 \mathrm{R}-2,87-92$ & 129.27 & 0.84 & -4.16 & & Cement, PLUC & Lincoln \\
\hline $873 \mathrm{~A}$ & $9 \mathrm{R}-2,125-129$ & 129.65 & 1.92 & -0.98 & & Red alga & Lincoln \\
\hline $873 \mathrm{~A}$ & $9 \mathrm{R}-2,125-129$ & 129.65 & 2.06 & -0.67 & & Cement, PLUC & Lincoln \\
\hline $873 \mathrm{~A}$ & $10 \mathrm{R}-1,40-45$ & 137.00 & 0.92 & -2.23 & & Rudist, calcite & Lincoln \\
\hline $873 \mathrm{~A}$ & $10 \mathrm{R}-1,40-45$ & 137.00 & 1.58 & -2.49 & & Cement, PLUC & Lincoln \\
\hline $873 \mathrm{~A}$ & $10 \mathrm{R}-1,40-45$ & 137.00 & 0.73 & -1.72 & & Internal sed? fine & Lincoln \\
\hline $873 \mathrm{~A}$ & $10 \mathrm{R}-1,40-45$ & 137.00 & 2.51 & -0.20 & & Internal sed? coarse & Lincoln \\
\hline $873 \mathrm{~A}$ & $10 \mathrm{R}-1,40-45$ & 137.00 & 1.99 & -0.60 & & Cement, PLUC & Lincoln \\
\hline $873 \mathrm{~A}$ & $10 \mathrm{R}-1,91-95$ & 137.51 & 2.39 & -0.84 & & Cement, PLUC & Lincoln \\
\hline $873 \mathrm{~A}$ & $11 R-1,14-16$ & 146.34 & 2.58 & -1.02 & & Cement, PLUC & Lincoln \\
\hline $873 \mathrm{~A}$ & $11 \mathrm{R}-1,54-59$ & 146.74 & 2.51 & -0.21 & & Cement, PLUC & Lincoln \\
\hline $873 \mathrm{~A}$ & $11 \mathrm{R}-1,98-102$ & 147.18 & 0.41 & -4.27 & & Rudist, calcite & Lincoln \\
\hline $873 \mathrm{~A}$ & $11 R-2,34-39$ & 147.99 & 1.50 & -2.34 & & Matrix & Lincoln \\
\hline $873 \mathrm{~A}$ & 1IR-2, 57-61 & 148.22 & 1.40 & -3.03 & & Rudist, calcite & Lincoln \\
\hline $873 \mathrm{~A}$ & $11 \mathrm{R}-2,90-98$ & 148.55 & 2.84 & -0.62 & & Cement, PLUC & Lincoln \\
\hline $873 \mathrm{~A}$ & $11 R-2,124-129$ & 148.89 & 1.67 & -1.66 & & Foraminifer, benthic & Lincoln \\
\hline $873 \mathrm{~A}$ & $11 \mathrm{R}-2,142-146$ & 149.07 & 1.46 & -1.64 & & Red alga & Lincoln \\
\hline $873 \mathrm{~A}$ & $11 \mathrm{R}-2,142-146$ & 149.07 & 1.94 & -0.79 & & Red alga, rhodolith & Lincoln \\
\hline $873 \mathrm{~A}$ & IIR- $2,142-146$ & 149.07 & 0.89 & -2.17 & & Red alga & Lincoln \\
\hline $873 \mathrm{~A}$ & $11 \mathrm{R}-2, \quad 142-146$ & 149.07 & 1.46 & -0.45 & & Cement, PLUC & Lincoln \\
\hline $873 \mathrm{~A}$ & $12 \mathrm{R}-1,0-5$ & 155.90 & 1.18 & -1.79 & & Cement, PLUC & Lincoln \\
\hline $874 \mathrm{~A}$ & $1 \mathrm{R}-1,14-18 \mathrm{~A}$ & 0.14 & 2.49 & -0.34 & & Cement, PLUC & Camoin et al. \\
\hline $874 \mathrm{~A}$ & $1 \mathrm{R}-1,4-18 \mathrm{~B}$ & 0.14 & 1.30 & -7.64 & & Rudist, calcite & Camoin et al. \\
\hline $874 \mathrm{~A}$ & $1 \mathrm{R}-1,23-26 \mathrm{~A}$ & 0.23 & 1.15 & -7.60 & & Rudist, calcite & Camoin et al. \\
\hline $874 \mathrm{~A}$ & $1 \mathrm{R}-1,23-26 \mathrm{~B}$ & 0.23 & 1.97 & -5.21 & & Cement, RC FIC & Camoin et al. \\
\hline $874 \mathrm{~A}$ & IR-1, 44-47 A & 0.44 & 1.98 & -1.17 & & Cement, RC FIC & Camoin et al. \\
\hline $874 \mathrm{~A}$ & $1 \mathrm{R}-1,44-47 \mathrm{~B}$ & 0.44 & 1.18 & -5.95 & & Rudist, calcite & Camoin et al. \\
\hline $874 \mathrm{~A}$ & IR-1, 76-79 & 0.76 & 3.03 & -0.92 & & Cement & Camoin et al. \\
\hline
\end{tabular}


Appendix (continued).

\begin{tabular}{|c|c|c|c|c|c|c|c|}
\hline Hole & $\begin{array}{l}\text { Core, section, } \\
\text { interval }(\mathrm{cm})\end{array}$ & $\begin{array}{l}\text { Depth } \\
\text { (mbsf) }\end{array}$ & $\delta^{13} \mathrm{C}$ & $\delta^{18} \mathrm{O}$ & ${ }^{87} \mathrm{Sr} /{ }^{86} \mathrm{Sr}$ & Component & Source \\
\hline $874 \mathrm{~A}$ & 1R-1, 108-114 & 1.08 & 2.78 & -1.65 & & Rudist, calcite & Camoin et al. \\
\hline $874 \mathrm{~B}$ & IR-1, 56-61 A & 0.59 & 1.95 & -2.75 & & Skel. fragment, calcite & Camoin et al. \\
\hline $874 \mathrm{~B}$ & IR-1, 56-61 B & 0.59 & 2.37 & -0.87 & & Skel. fragment, calcite & Camoin et al. \\
\hline $874 \mathrm{~B}$ & $1 \mathrm{R}-1,122-128 \mathrm{~A}$ & 1.25 & 2.77 & -0.41 & & Cement, RC FIC & Camoin et al. \\
\hline $874 \mathrm{~B}$ & $1 \mathrm{R}-1,122-128 \mathrm{~B}$ & 1.25 & 2.63 & 0.07 & & Cement, PLUC & Camoin et al. \\
\hline $874 B$ & $5 R-1,17-22$ & 38.30 & 1.46 & -1.62 & & Cement, CC & Camoin et al. \\
\hline $877 \mathrm{~A}$ & $2 \mathrm{R}-1,49-52$ & 10.00 & 1.43 & -2.92 & & Skel. fragment, calcite & Camoin et al. \\
\hline $877 \mathrm{~A}$ & $3 R-1,4-8$ & 19.06 & 1.97 & -1.01 & & Cement, RC & Camoin et al. \\
\hline $877 \mathrm{~A}$ & $3 R-1,11-15$ & 19.13 & 1.81 & -1.18 & & Cement, RC & Camoin et al. \\
\hline $877 \mathrm{~A}$ & $4 \mathrm{R}-1,11-14$ & 28.52 & 3.15 & -3.65 & & Skel. fragment, calcite & Camoin et al. \\
\hline $877 \mathrm{~A}$ & $4 \mathrm{R}-1,79-83 \mathrm{~A}$ & 29.21 & 2.53 & -0.57 & & Skel. fragment, calcite & Camoin et al. \\
\hline $877 \mathrm{~A}$ & $4 \mathrm{R}-1,79-83 \mathrm{~B}$ & 29.21 & 2.36 & -1.24 & & Cement, PLUC & Camoin et al. \\
\hline $877 \mathrm{~A}$ & $4 \mathrm{R}-1,103-107$ & 29.45 & 1.85 & -1.55 & & Cement, PLUC & Camoin et al. \\
\hline $877 \mathrm{~A}$ & $4 R-2,30-37$ & 30.25 & 1.91 & -1.56 & & Cement, PLUC & Camoin et al. \\
\hline $877 \mathrm{~A}$ & $4 \mathrm{R}-2,89-93$ & 30.82 & 2.33 & -1.14 & & Cement, PLUC & Camoin et al. \\
\hline $877 \mathrm{~A}$ & $4 \mathrm{R}-3,31-33$ & 31.73 & 2.06 & -1.46 & & Cement, RC FIC & Camoin et al. \\
\hline $877 \mathrm{~A}$ & $5 \mathrm{R}-1,3-8$ & 38.05 & 2.05 & -1.01 & & Rudist, calcite & Camoin et al. \\
\hline $877 \mathrm{~A}$ & $5 R-1,91-93 A$ & 38.92 & 1.74 & -1.66 & & Coral, calcite & Camoin et al. \\
\hline $877 \mathrm{~A}$ & $5 R-1,91-93$ B & 38.92 & 1.99 & -1.60 & & Cement, RC & Camoin et al. \\
\hline $877 \mathrm{~A}$ & $5 \mathrm{R}-1,106-110$ & 39.08 & 2.31 & -0.78 & & Skel. fragment, calcite & Camoin et al. \\
\hline $877 \mathrm{~A}$ & $5 R-2,122-127$ & 40.69 & 2.78 & 0.07 & & Rudist, calcite & Camoin et al. \\
\hline $877 \mathrm{~A}$ & $5 R-3,4-7$ & 41.00 & 2.63 & -0.13 & & Rudist, calcite & Camoin et al. \\
\hline $877 \mathrm{~A}$ & $5 R-3,31-36$ & 41.29 & 4.78 & -1.07 & & Rudist, aragonite & Camoin et al. \\
\hline $877 \mathrm{~A}$ & $5 \mathrm{R}-3,37-39 \mathrm{~A}$ & 41.33 & 6.35 & -1.12 & & Rudist, aragonite & Camoin et al. \\
\hline $877 \mathrm{~A}$ & $5 R-3,37-39$ B & 41.33 & 4.90 & -1.11 & & Rudist, aragonite & Camoin et al. \\
\hline $877 \mathrm{~A}$ & $5 R-3,44-55$ & 41.41 & 4.87 & -1.32 & & Rudist, aragonite & Camoin et al. \\
\hline $877 \mathrm{~A}$ & $5 R-3,46-50$ & 41.43 & 4.53 & -1.13 & & Rudist, aragonite & Camoin et al. \\
\hline $877 \mathrm{~A}$ & $5 \mathrm{R}-3,46-50 \mathrm{~A}$ & 41.43 & 3.05 & -5.19 & & Neomorphic calcite & Camoin et al. \\
\hline $877 \mathrm{~A}$ & $5 R-3,46-50 \mathrm{~B}$ & 41.43 & 2.69 & -0.34 & & Cement, RC FIC & Camoin et al. \\
\hline $877 \mathrm{~A}$ & $5 \mathrm{R}-3,72-74$ & 41.68 & 4.98 & -0.94 & & Rudist, aragonite & Camoin et al. \\
\hline $877 \mathrm{~A}$ & $5 R-3,126-129$ & 42.23 & 2.16 & -1.48 & & Cement, PLUC & Camoin et al. \\
\hline $877 \mathrm{~A}$ & $7 \mathrm{R}-1,136-140$ & 58.68 & 4.64 & 0.97 & & Rudist, aragonite & Camoin et al. \\
\hline $877 \mathrm{~A}$ & $7 \mathrm{R}-2, \quad 23-27$ & 59.05 & 2.30 & -0.37 & & Cement, PLUC & Camoin et al. \\
\hline $877 \mathrm{~A}$ & $1 \mathrm{R}-1,104-108$ & 1.04 & 2.16 & -1.02 & & Matrix & Wilson \\
\hline $877 \mathrm{~A}$ & IR-1, $104-108$ & 1.04 & 2.23 & -1.12 & & Cement, RC & Wilson \\
\hline $877 \mathrm{~A}$ & IR-1, $104-108$ & 1.04 & 2.42 & -0.14 & & Skel. fragment & Wilson \\
\hline $877 \mathrm{~A}$ & IR-1, 34-36 & 0.34 & 2.31 & -0.9 & 0.708095 & Cement, RC & Wilson \\
\hline $877 \mathrm{~A}$ & IR-1, $34-36$ & 0.34 & 2.14 & -1.58 & 0.707953 & Matrix & Wilson \\
\hline $877 \mathrm{~A}$ & IR-1, 99-101 & 0.99 & 1.9 & -1 & & Internal sed? micrite & Wilson \\
\hline $877 \mathrm{~A}$ & IR-1, 99-101 & 0.99 & 1.97 & -0.94 & & Matrix & Wilson \\
\hline $877 \mathrm{~A}$ & $1 \mathrm{R}-2,55-62$ & 2.03 & & & 0.707785 & Rudist, calcite & Wilson \\
\hline $877 \mathrm{~A}$ & IR-2, 85-87 & 2.33 & 1.44 & -3.7 & & Rudist, calcite & Wilson \\
\hline $877 \mathrm{~A}$ & $1 \mathrm{R}-2,85-87$ & 2.33 & 0.76 & -2.57 & & Rudist, aragonite & Wilson \\
\hline $877 \mathrm{~A}$ & $1 \mathrm{R}-2,85-87$ & 2.33 & 1.26 & -2.17 & & Cement, RC & Wilson \\
\hline $877 \mathrm{~A}$ & $1 \mathrm{R}-2,85-87$ & 2.33 & 1.69 & -1.93 & & Matrix & Wilson \\
\hline $877 \mathrm{~A}$ & $1 \mathrm{R}-2,85-87$ & 2.33 & 1.46 & -4.53 & & Rudist, calcite & Wilson \\
\hline $877 \mathrm{~A}$ & $2 \mathrm{R}-1,39-42$ & 9.89 & 2.45 & -0.92 & & Cement, PLUC & Wilson \\
\hline $877 \mathrm{~A}$ & $2 R-1,39-42$ & 9.89 & 2.01 & -0.41 & & Matrix & Wilson \\
\hline $877 \mathrm{~A}$ & $2 \mathrm{R}-1,39-42$ & 9.89 & 2.54 & -0.99 & & Cement, PLUC & Wilson \\
\hline $877 \mathrm{~A}$ & $2 \mathrm{R}-1,53-56$ & 10.03 & 2.42 & -0.58 & 0.708635 & Cement, PLUC & Wilson \\
\hline $877 \mathrm{~A}$ & $2 \mathrm{R}-1,53-56$ & 10.03 & 1.06 & -1.88 & 0.708298 & Matrix & Wilson \\
\hline $877 \mathrm{~A}$ & $3 R-1,2-4$ & 19.02 & 2.24 & -0.12 & & Cement, RC & Wilson \\
\hline $877 \mathrm{~A}$ & $3 R-1,2-4$ & 19.02 & 1.68 & -0.9 & & Matrix & Wilson \\
\hline $877 \mathrm{~A}$ & $3 \mathrm{R}-1,21-23$ & 19.21 & 2.07 & -4.16 & 0.707788 & Rudist, calcite & Wilson \\
\hline $877 \mathrm{~A}$ & $3 \mathrm{R}-1,21-23$ & 19.21 & 1.63 & -2.55 & 0.707771 & Rudist, calcite & Wilson \\
\hline $877 \mathrm{~A}$ & $3 \mathrm{R}-1,21-23$ & 19.21 & & & 0.707823 & Cement, PLUC? & Wilson \\
\hline $877 \mathrm{~A}$ & $3 R-1,21-23$ & 19.21 & & & 0.707963 & Matrix & Wilson \\
\hline $877 \mathrm{~A}$ & $4 R-1,135-137$ & 29.75 & 2.1 & -1.36 & & Skel. fragment & Wilson \\
\hline $877 \mathrm{~A}$ & $4 \mathrm{R}-1, \quad 135-137$ & 29.75 & & & 0.707771 & Rudist, calcite & Wilson \\
\hline $877 \mathrm{~A}$ & $4 \mathrm{R}-1,135-137$ & 29.75 & 1.81 & -2.1 & 0.707830 & Cement, PLUC & Wilson \\
\hline $877 \mathrm{~A}$ & $4 R-2,64-65$ & 30.55 & 1.76 & -3.68 & 0.707812 & Rudist, calcite & Wilson \\
\hline $877 \mathrm{~A}$ & $4 R-2,64-65$ & 30.55 & 1.64 & -2.49 & & Rudist, aragonite & Wilson \\
\hline $877 \mathrm{~A}$ & $4 R-2,64-65$ & 30.55 & 1.46 & -1.69 & & Cement, PLUC & Wilson \\
\hline $877 \mathrm{~A}$ & $4 \mathrm{R}-3,17-22$ & 31.58 & 1.9 & -1.98 & & Cement, yellow & Wilson \\
\hline $877 \mathrm{~A}$ & $4 \mathrm{R}-3,17-22$ & 31.58 & 1.17 & -2.3 & & Red alga & Wilson \\
\hline $877 \mathrm{~A}$ & $4 \mathrm{R}-3,17-22$ & 31.58 & 1.4 & -3.32 & & Cement, RC & Wilson \\
\hline $877 \mathrm{~A}$ & $5 R-1,69-73$ & 38.69 & 2.51 & -1.1 & 0.707784 & Rudist, aragonite? & Wilson \\
\hline $877 \mathrm{~A}$ & $5 R-1,69-73$ & 38.69 & 2.33 & -1.2 & & Cement, columnar & Wilson \\
\hline $877 \mathrm{~A}$ & $5 \mathrm{R}-1,69-73$ & 38.69 & 2.42 & -1.07 & 0.707817 & Cement, PLUC & Wilson \\
\hline $877 \mathrm{~A}$ & $5 \mathrm{R}-1,141-142$ & 39.41 & & & 0.707721 & Cement & Wilson \\
\hline $877 \mathrm{~A}$ & $5 R-2,11-14$ & 39.59 & 2.12 & -2.15 & & Foraminifer, benthic & Wilson \\
\hline $877 \mathrm{~A}$ & $5 R-2,11-14$ & 39.59 & 2.09 & -2.03 & & Cement, PLUC & Wilson \\
\hline $877 \mathrm{~A}$ & $5 R-3,105-108$ & 42.04 & 2.92 & -1.97 & & Rudist, aragonite & Wilson \\
\hline $877 \mathrm{~A}$ & $5 R-3,105-108$ & 42.04 & 2.25 & -2.16 & & Rudist, aragonite & Wilson \\
\hline $877 \mathrm{~A}$ & $5 R-3,105-108$ & 42.04 & 2.07 & -1.94 & & Rudist, aragonite & Wilson \\
\hline $877 \mathrm{~A}$ & $5 R-3,105-108$ & 42.04 & 3.06 & -2.65 & & Rudist, well preserved & Wilson \\
\hline $877 \mathrm{~A}$ & $5 R-3,105-108$ & 42.04 & 2.39 & -1.44 & & Rudist, aragonite & Wilson \\
\hline $877 \mathrm{~A}$ & $5 R-3,105-108$ & 42.04 & 2.87 & 0.17 & & Rudist, aragonite & Wilson \\
\hline $877 \mathrm{~A}$ & $5 R-3,105-108$ & 42.04 & 3.34 & -2.87 & & Rudist, well preserved & Wilson \\
\hline $877 \mathrm{~A}$ & $5 R-3,105-108$ & 42.04 & 2.88 & -2.32 & & Cement, columnar & Wilson \\
\hline $877 \mathrm{~A}$ & $5 R-3,37-39$ & 41.36 & 2.4 & -2.51 & & Rudist, well preserved & Wilson \\
\hline $877 \mathrm{~A}$ & $5 R-3,37-39$ & 41.36 & 3.11 & 1.25 & & Rudist, aragonite & Wilson \\
\hline $877 \mathrm{~A}$ & $5 R-3,37-39$ & 41.36 & 2.53 & -2.8 & & Rudist, aragonite & Wilson \\
\hline $877 \mathrm{~A}$ & $5 \mathrm{R}-3,37-39$ & 41.36 & 2.95 & -2.19 & & Cement, columnar & Wilson \\
\hline $877 \mathrm{~A}$ & $5 R-3,37-39$ & 41.36 & 2.55 & -2.33 & & Rudist, aragonite & Wilson \\
\hline $877 \mathrm{~A}$ & $5 R-3,41-44$ & 41.4 & 2.92 & -0.2 & & Rudist, aragonite & Wilson \\
\hline $877 \mathrm{~A}$ & $5 R-3,41-44$ & 41.4 & 2.94 & -1.87 & 0.707823 & Rudist, aragonite & Wilson \\
\hline $877 \mathrm{~A}$ & $5 R-3,41-44$ & 41.4 & 3.18 & -2.83 & & Rudist, well preserved & Wilson \\
\hline $877 \mathrm{~A}$ & $5 R-3,41-44$ & 41.4 & 2.97 & -2.63 & 0.707767 & Cement, columnar & Wilson \\
\hline $877 \mathrm{~A}$ & $5 R-3,41-45$ & 41.4 & 2.44 & -2.39 & & Cement, columnar & Wilson \\
\hline
\end{tabular}


Appendix (continued).

\begin{tabular}{|c|c|c|c|c|c|c|c|}
\hline Hole & $\begin{array}{l}\text { Core, section, } \\
\text { interval }(\mathrm{cm})\end{array}$ & $\begin{array}{l}\text { Depth } \\
\text { (mbsf) }\end{array}$ & $\delta^{13} \mathrm{C}$ & $\delta^{18} \mathrm{O}$ & ${ }^{87} \mathrm{Sr} /{ }^{86} \mathrm{Sr}$ & Component & Source \\
\hline $877 \mathrm{~A}$ & $5 R-3,41-45$ & 41.4 & & & 0.707859 & Rudist, calcite & Wilson \\
\hline 877A & $5 R-3,41-45$ & 41.4 & & & 0.707854 & Rudist, calcite & Wilson \\
\hline $877 \mathrm{~A}$ & $5 R-3,74-76$ & 41.73 & 3.05 & -0.16 & & Rudist, aragonite & Wilson \\
\hline $877 \mathrm{~A}$ & $5 R-3,74-76$ & 41.73 & 2.91 & -2.51 & & Rudist, aragonite & Wilson \\
\hline $877 \mathrm{~A}$ & $5 R-3,74-76$ & 41.73 & 2.76 & -2.45 & & Cement, columnar & Wilson \\
\hline $877 \mathrm{~A}$ & $5 R-3,74-76$ & 41.73 & 3.13 & 1.11 & & Cement, PLUC & Wilson \\
\hline $877 \mathrm{~A}$ & $5 R-3,74-76$ & 41.73 & 1.4 & -4.33 & & Rudist, calcite & Wilson \\
\hline $877 \mathrm{~A}$ & $5 R-3,74-76$ & 41.73 & 2.98 & -1.56 & & Cement, aragonite & Wilson \\
\hline $877 \mathrm{~A}$ & $5 R-3,74-76$ & 41.73 & 2.81 & -2.57 & & Rudist, well preserved & Wilson \\
\hline $877 \mathrm{~A}$ & $5 \mathrm{R}-3,74-76$ & 41.73 & 2.96 & -1.51 & & Rudist, aragonite & Wilson \\
\hline $877 \mathrm{~A}$ & $5 R-3,74-76$ & 41.73 & & & 0.707775 & Matrix & Wilson \\
\hline $877 \mathrm{~A}$ & $5 R-3,76-78$ & 41.75 & 2.9 & 1.28 & & Rudist, aragonite & Wilson \\
\hline $877 \mathrm{~A}$ & $5 R-3,76-78$ & 41.75 & 2.64 & -2.52 & & Rudist, well preserved & Wilson \\
\hline $877 \mathrm{~A}$ & $5 \mathrm{R}-3,76-78$ & 41.75 & 2.41 & -2.36 & & Rudist, well preserved & Wilson \\
\hline 877A & $5 R-3,76-78$ & 41.75 & 3.37 & -2.55 & & Cement, columnar & Wilson \\
\hline $877 \mathrm{~A}$ & SR-3, 76-78 & 41.75 & 4.46 & -3.02 & & Coral & Wilson \\
\hline $877 \mathrm{~A}$ & 5R-3, 93-96 & 41.92 & 2.52 & -1.99 & & Rudist, well preserved & Wilson \\
\hline $877 \mathrm{~A}$ & $5 R-3,93-96$ & 41.92 & 2.9 & -2.47 & & Rudist, well preserved & Wilson \\
\hline $877 \mathrm{~A}$ & 5R-3, 93-96 & 41.92 & 3.87 & -2.52 & & Rudist, well preserved & Wilson \\
\hline $877 \mathrm{~A}$ & $6 \mathrm{R}-1,12-15$ & 47.72 & 2.58 & -1.1 & 0.708243 & Matrix & Wilson \\
\hline $877 \mathrm{~A}$ & $6 \mathrm{R}-1,12-15$ & 47.72 & 2.58 & -1.13 & & Matrix & Wilson \\
\hline $877 \mathrm{~A}$ & $6 R-1,12-15$ & 47.72 & 1.83 & -1.41 & & Skel. fragment & Wilson \\
\hline $877 \mathrm{~A}$ & $6 \mathrm{R}-1,12-15$ & 47.72 & 2.58 & -1.31 & & Matrix & Wilson \\
\hline $877 \mathrm{~A}$ & $6 \mathrm{R}-1,4-8$ & 47.64 & 1.87 & -0.91 & & Cement, PLUC & Wilson \\
\hline $877 \mathrm{~A}$ & $6 \mathrm{R}-1,4-8$ & 47.64 & 1.62 & -2.25 & & Rudist, aragonite & Wilson \\
\hline $877 \mathrm{~A}$ & $7 \mathrm{R}-1,24-28$ & 57.54 & 0.72 & -4.01 & & Rudist, calcite & Wilson \\
\hline $877 \mathrm{~A}$ & $7 R-1,38-41$ & 57.68 & 1.38 & -4.27 & & Rudist, calcite & Wilson \\
\hline $877 \mathrm{~A}$ & $7 \mathrm{R}-1,38-41$ & 57.68 & 1.72 & -1.78 & & Rudist, aragonite & Wilson \\
\hline $877 \mathrm{~A}$ & $7 \mathrm{R}-1,38-41$ & 57.68 & 1.92 & -1.62 & & Cement, RC & Wilson \\
\hline $877 \mathrm{~A}$ & $7 \mathrm{R}-1,38-41$ & 57.68 & 1.33 & -4.96 & & Rudist, calcite & Wilson \\
\hline $877 \mathrm{~A}$ & $7 \mathrm{R}-1,38-41$ & 57.68 & 1.68 & -1.81 & 0.707808 & Matrix & Wilson \\
\hline $877 \mathrm{~A}$ & $7 \mathrm{R}-2,4-8$ & 58.84 & & & 0.707789 & Rudist, calcite & Wilson \\
\hline $877 \mathrm{~A}$ & 7R-2, $104-106$ & 59.84 & 1.29 & -2.43 & 0.707786 & Rudist, calcite & Wilson \\
\hline $877 \mathrm{~A}$ & $7 R-2,104-106$ & 59.84 & 2.06 & -0.81 & 0.707797 & Cement, RC & Wilson \\
\hline $877 \mathrm{~A}$ & $8 \mathrm{R}-1,18-22$ & 67.18 & 1.7 & -1.72 & & Rudist, aragonite & Wilson \\
\hline $877 \mathrm{~A}$ & $8 \mathrm{R}-1,18-22$ & 67.18 & 1.65 & -2.98 & & Rudist, calcite & Wilson \\
\hline $877 \mathrm{~A}$ & $8 R-1,18-22$ & 67.18 & 1.53 & -4.34 & 0.707780 & Rudist, calcite & Wilson \\
\hline $877 \mathrm{~A}$ & $8 \mathrm{R}-1,18-22$ & 67.18 & 1.03 & -2.97 & & Rudist, aragonite & Wilson \\
\hline $877 \mathrm{~A}$ & $8 R-1,18-22$ & 67.18 & 1.86 & -0.27 & & Cement, PLUC & Wilson \\
\hline $877 \mathrm{~A}$ & $8 \mathrm{R}-1,45-48$ & 67.45 & 1.04 & -2.08 & & Rudist, aragonite & Wilson \\
\hline $877 \mathrm{~A}$ & $8 \mathrm{R}-1,45-48$ & 67.45 & 1.22 & -1.26 & & Cement, RC & Wilson \\
\hline $877 \mathrm{~A}$ & $8 R-1,45-48$ & 67.45 & 1.23 & -1.43 & 0.707795 & Cement, PLUC & Wilson \\
\hline $877 \mathrm{~A}$ & $8 R-1,45-48$ & 67.45 & & & 0.707787 & Rudist, calcite & Wilson \\
\hline $877 \mathrm{~A}$ & $9 R-1,21-25$ & 76.81 & 0.77 & -1.67 & & Red alga? & Wilson \\
\hline $877 \mathrm{~A}$ & $9 \mathrm{R}-1,21-25$ & 76.81 & 1.16 & -1.02 & & Coral? & Wilson \\
\hline $877 \mathrm{~A}$ & $9 \mathrm{R}-1,21-25$ & 76.81 & 1.23 & -1.03 & & Skel. fragment & Wilson \\
\hline $877 \mathrm{~A}$ & $9 \mathrm{R}-1,21-25$ & 76.81 & 1.27 & -1.04 & & Cement, PLUC & Wilson \\
\hline $877 \mathrm{~A}$ & $9 \mathrm{R}-1,21-25$ & 76.81 & & & 0.707768 & Coral & Wilson \\
\hline $877 \mathrm{~A}$ & $10 \mathrm{R}-1,3-10$ & 86.33 & 1.33 & -0.84 & & Cement, PLUC & Wilson \\
\hline $877 \mathrm{~A}$ & $10 \mathrm{R}-1,3-10$ & 86.33 & 1.57 & -1.06 & 0.707831 & Coral, aragonitic? & Wilson \\
\hline $877 \mathrm{~A}$ & $14 \mathrm{R}-1,21-22$ & 125.21 & & & 0.708093 & Matrix & Wilson \\
\hline $877 \mathrm{~A}$ & $14 \mathrm{R}-2,13-17$ & 126.63 & & & 0.708045 & Matrix & Wilson \\
\hline $877 \mathrm{~A}$ & $16 R-1,0-7$ & 144.3 & & & 0.708280 & Matrix & Wilson \\
\hline $877 \mathrm{~A}$ & $17 \mathrm{R}-1,11-15$ & 154.01 & 1.5 & -1.33 & 0.707783 & Matrix & Wilson \\
\hline $877 \mathrm{~A}$ & $17 \mathrm{R}-2,11-15$ & 154.01 & 1.13 & -1.38 & & Foraminifer, benthic & Wilson \\
\hline $877 \mathrm{~A}$ & $18 \mathrm{R}-1,47-48$ & 163.97 & 0.62 & -1.96 & & Foraminifer, benthic & Wilson \\
\hline $877 \mathrm{~A}$ & $18 \mathrm{R}-1,47-48$ & 163.97 & 0.81 & -1.14 & & Skel. fragment & Wilson \\
\hline $877 \mathrm{~A}$ & $18 \mathrm{R}-1,47-48$ & 163.97 & 0.66 & -1.31 & & Matrix & Wilson \\
\hline $877 \mathrm{~A}$ & $18 \mathrm{R}-1,77-78$ & 164.27 & 1.86 & -0.92 & 0.708128 & Matrix & Wilson \\
\hline $877 \mathrm{~A}$ & $19 \mathrm{R}-1,27-30$ & 173.47 & 0.76 & -2.34 & & Matrix, Fe stained & Wilson \\
\hline $877 \mathrm{~A}$ & $19 \mathrm{R}-1,27-30$ & 173.47 & 0.56 & -2.3 & 0.708210 & Matrix & Wilson \\
\hline $874 A$ & IR-1, 73-75 & 0.73 & 2.62 & -0.42 & 0.707809 & Cement, RC FIC & Wyatt, Quinn, Davies \\
\hline $874 \mathrm{~A}$ & IR-1, $108-115$ & 1.08 & 0.92 & -4.34 & 0.707817 & Rudist & Wyatt, Quinn, Davies \\
\hline $874 \mathrm{~A}$ & $1 \mathrm{R}-1,108-115$ & 1.08 & 2.61 & -0.99 & & Cement, RC & Wyatt, Quinn, Davies \\
\hline $874 \mathrm{~A}$ & IR-2, 7-11 & 1.57 & 2.34 & -1.53 & & Cement & Wyatt, Quinn, Davies \\
\hline $874 \mathrm{~B}$ & IR-1, 47-50 & 0.47 & 2.33 & -0.20 & & Cement, RC & Wyatt, Quinn, Davies \\
\hline $874 \mathrm{~B}$ & $2 \mathrm{R}-1,25-30$ & 9.95 & 2.31 & -0.66 & 0.707830 & Cement, RC & Wyatt, Quinn, Davies \\
\hline $874 \mathrm{~B}$ & $2 \mathrm{R}-1,25-30$ & 9.95 & 1.79 & -0.52 & & Matrix & Wyatt, Quinn, Davies \\
\hline $874 \mathrm{~B}$ & $2 \mathrm{R}-1,45-47$ & 10.15 & 1.57 & -0.52 & 0.707849 & Matrix & Wyatt, Quinn, Davies \\
\hline $874 \mathrm{~B}$ & $2 \mathrm{R}-1,45-47$ & 10.15 & 2.01 & -1.39 & & Rudist & Wyatt, Quinn, Davies \\
\hline $874 \mathrm{~B}$ & $2 \mathrm{R}-1,96-100$ & 10.66 & 1.77 & -4.12 & & Rudist & Wyatt, Quinn, Davies \\
\hline $874 \mathrm{~B}$ & $3 R-1,63-68$ & 19.83 & 2.48 & -0.55 & & Cement, RC & Wyatt, Quinn, Davies \\
\hline 874B & $3 R-1,138-140$ & 20.58 & 1.32 & -1.70 & 0.707860 & Matrix & Wyatt, Quinn, Davies \\
\hline 874B & $3 R-2,48-52$ & 21.15 & 1.42 & -0.73 & & Cement, PLUC & Wyatt, Quinn, Davies \\
\hline $874 B$ & $4 \mathrm{R}-1,36-42$ & 29.06 & 1.78 & -1.51 & & Matrix & Wyatt, Quinn, Davies \\
\hline $874 \mathrm{~B}$ & SR-1, 0-6 & 38.1 & 3.13 & -3.66 & & Rudist & Wyatt, Quinn, Davies \\
\hline $874 \mathrm{~B}$ & SR-2, 102-108 & 40.62 & 1.59 & -4.11 & 0.707850 & Rudist & Wyatt, Quinn, Davies \\
\hline $874 \mathrm{~B}$ & $5 R-2,102-108$ & 40.62 & 2.20 & -3.40 & & Mollusc & Wyatt, Quinn, Davies \\
\hline $874 \mathrm{~B}$ & $6 \mathrm{R}-1,114-117$ & 48.74 & 1.73 & -1.68 & 0.707840 & Matrix & Wyatt, Quinn, Davies \\
\hline 874B & $6 \mathrm{R}-1,114-117$ & 48.74 & 1.92 & -1.02 & & Cement, PLUC & Wyatt, Quinn, Davies \\
\hline $874 \mathrm{~B}$ & $7 R-1,10-14$ & 57.3 & 1.51 & -3.07 & & Rudist & Wyatt, Quinn, Davies \\
\hline $874 B$ & $8 \mathrm{R}-1,4-7$ & 66.94 & 1.01 & -1.58 & 0.707834 & Matrix & Wyatt, Quinn, Davies \\
\hline $874 \mathrm{~B}$ & I0R-1,0-4 & 86.2 & 1.98 & -0.62 & 0.707800 & Matrix & Wyatt, Quinn, Davies \\
\hline $874 \mathrm{~B}$ & $11 \mathrm{R}-1,7-10$ & 91.27 & 1.70 & -0.58 & 0.707851 & Rudist & Wyatt, Quinn, Davies \\
\hline $874 \mathrm{~B}$ & $19 \mathrm{R}-1,53-55$ & 144.03 & 2.54 & -1.97 & & Cement, PLUC & Wyatt, Quinn, Davies \\
\hline $874 \mathrm{~B}$ & 19R-1, 93-99 & 144.43 & 2.55 & -1.63 & & Cement, PLUC & Wyatt, Quinn, Davies \\
\hline $874 \mathrm{~B}$ & $2 \mathrm{R}-1,42-45$ & 10.12 & 2.12 & -0.75 & & Matrix & Lincoln \\
\hline $874 \mathrm{~B}$ & $2 \mathrm{R}-1,42-45$ & 10.12 & 2.16 & -0.62 & & Matrix & Lincoln \\
\hline $874 B$ & $2 \mathrm{R}-1,42-45$ & 10.12 & 2.07 & -0.32 & & Cement, PLUC & Lincoln \\
\hline 874B & $2 \mathrm{R}-1,42-45$ & 10.12 & 1.62 & -2.31 & & Rudist & Lincoln \\
\hline
\end{tabular}


DIAGENESIS OF PLATFORM CARBONATES, WODEJEBATO GUYOT

Appendix (continued).

\begin{tabular}{|c|c|c|c|c|c|c|c|}
\hline Hole & $\begin{array}{l}\text { Core, section, } \\
\text { interval }(\mathrm{cm})\end{array}$ & $\begin{array}{l}\text { Depth } \\
\text { (mbsf) }\end{array}$ & $\delta^{13} \mathrm{C}$ & $\delta^{18} \mathrm{O}$ & ${ }^{87} \mathrm{Sr} /{ }^{86} \mathrm{Sr}$ & Component & Source \\
\hline 874B & $2 \mathrm{R}-1,120-125$ & 10.9 & 2.67 & -0.79 & & Cement, PLUC & Lincoln \\
\hline $874 B$ & $10 \mathrm{R}-1,0-4$ & 86.2 & 2.52 & -1.18 & & Rudist & Lincoln \\
\hline $874 \mathrm{~B}$ & $10 \mathrm{R}-1,0-4$ & 86.2 & 2 & -0.35 & & Cement, PLUC & Lincoln \\
\hline $874 \mathrm{~B}$ & $10 \mathrm{R}-1,0-4$ & 86.2 & 2.01 & -0.46 & & Foraminifer, benthic & Lincoln \\
\hline $874 B$ & $12 R-1,0-4$ & 86.2 & 1.78 & -0.8 & & Rudist & Lincoln \\
\hline $874 \mathrm{~B}$ & $12 \mathrm{R}-1,0-4$ & 86.2 & 1.76 & -0.76 & & Foraminifer, benthic & Lincoln \\
\hline $874 \mathrm{~B}$ & $12 \mathrm{R}-1,0-4$ & 86.2 & 1.9 & -0.44 & & Cement, PLUC & Lincoln \\
\hline $874 \mathrm{~B}$ & $18 \mathrm{R}-1,59-61$ & 136.59 & 1.89 & 0.03 & & Matrix & Lincoln \\
\hline $874 B$ & $19 R-1,4-6$ & 143.54 & 2.66 & -1.76 & & Cement, PLUC & Lincoln \\
\hline $874 B$ & $19 \mathrm{R}-1,25-28$ & 143.75 & 2.42 & -2.23 & & Foraminifer, benthic & Lincoln \\
\hline $874 \mathrm{~B}$ & $19 \mathrm{R}-1,25-28$ & 143.75 & 2.7 & -1.2 & & Cement, PLUC & Lincoln \\
\hline $874 \mathrm{~B}$ & $19 \mathrm{R}-1,25-28$ & 143.75 & 2.64 & -1.71 & & Cement, PLUC & Lincoln \\
\hline $874 \mathrm{~B}$ & $19 \mathrm{R}-1,58-61$ & 144.08 & 2.18 & -2.12 & & Red alga & Lincoln \\
\hline $874 \mathrm{~B}$ & $19 \mathrm{R}-1,58-61$ & 144.08 & 2.56 & -1.78 & & Cement, PLUC & Lincoln \\
\hline $874 \mathrm{~B}$ & $19 \mathrm{R}-1,58-61$ & 144.08 & 2.48 & -2.39 & & Foraminifer, benthic & Lincoln \\
\hline $874 \mathrm{~B}$ & $19 \mathrm{R}-1,58-61$ & 144.08 & 2.77 & -1.75 & & Cement, PLUC & Lincoln \\
\hline
\end{tabular}

Note: PLUC = prismatic limpid cement with uniform extinction; $\mathrm{RC}=$ radiaxial cement; $\mathrm{FIC}=$ fibrous, inclusion-rich cement; $\mathrm{CC}=$ columnar cement. 